\title{
Language Change in Two Early English Printing Houses: Richard Pynson and Wynkyn de Worde, 1490-1530
}

\section{Alana Cruikshank}

A thesis submitted to the Victoria University of Wellington in fulfilment of the requirement for the degree of Master of Arts Victoria University of Wellington 


\section{Table of contents}

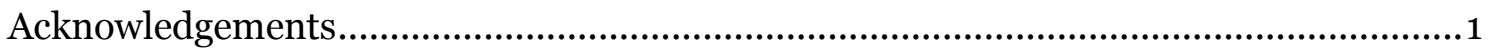

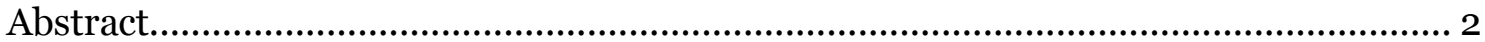

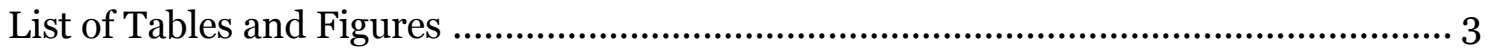

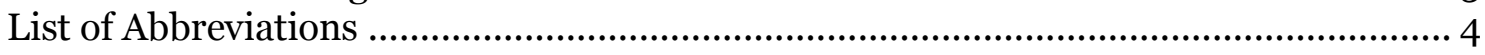

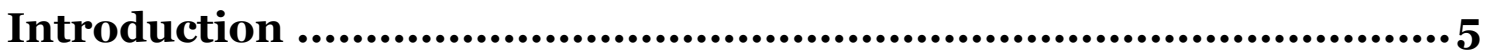

Review of scholarship ........................................................... 16

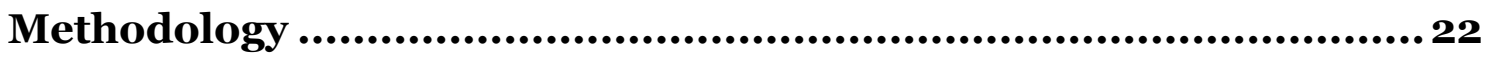

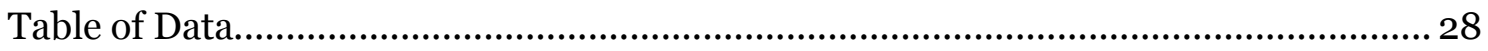

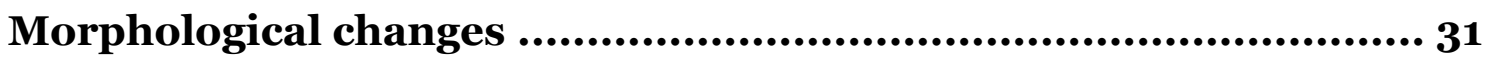

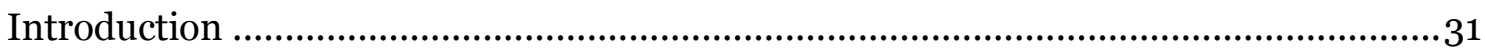

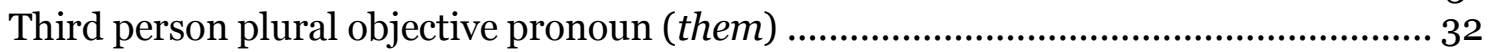

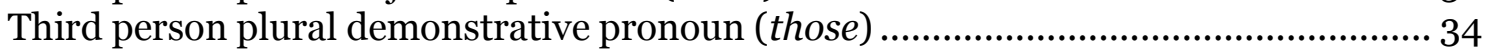

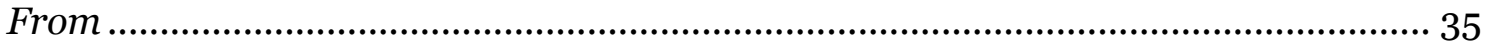

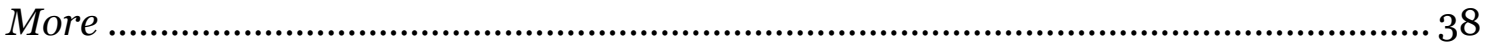

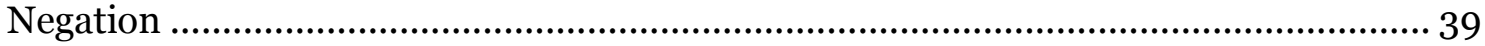

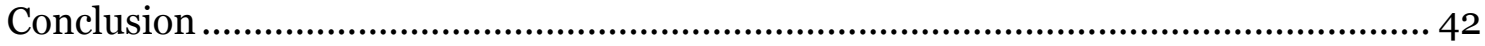

Orthographic changes ...............................................................44

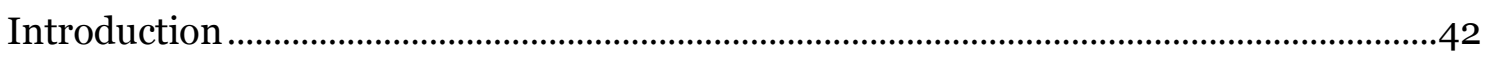

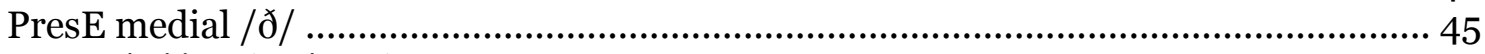

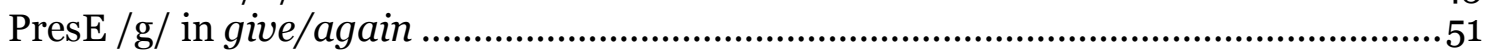

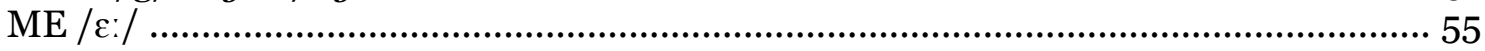

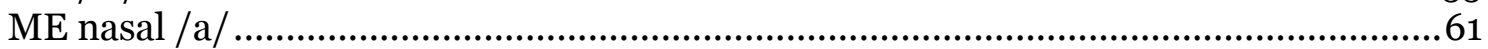

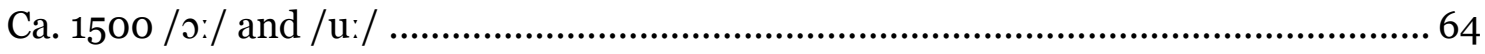

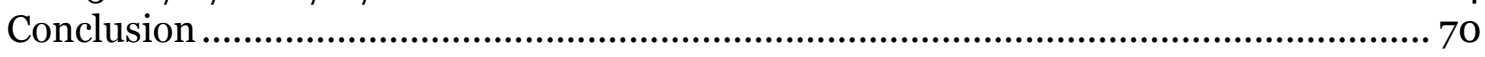

Conclusion .............................................................................73

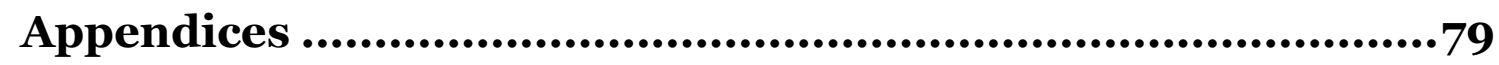

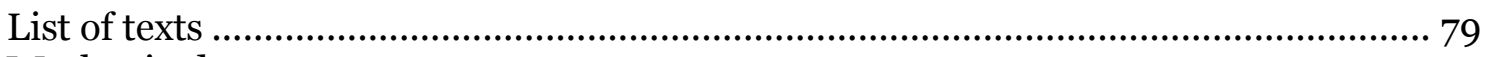

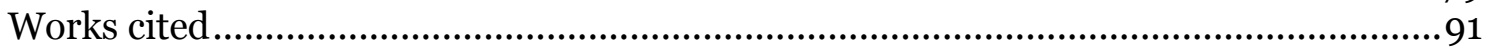




\section{Acknowledgements}

I could not have completed this thesis without the guidance and support of a number of very special people. First and foremost, I would like to thank my supervisor Peter Whiteford for his patience, feedback, and support throughout the duration of my thesis, and also for guiding and sustaining my enthusiasm for medieval literature throughout my undergraduate and postgraduate years. Thank you also to Elizabeth Pearce for inspiring me to pursue the field of historical language study, and to Christine Franzen for introducing me to medieval studies in my first year of university and briefly entertaining my passion before her retirement.

My deepest love and thanks to my fiancé Ben for his enduring kindness, care, and support, both at home and from afar, and for guiding me through when I felt close to giving up. A very special thank you also goes out to my parents, for their unwavering love and confidence in me. I would like to thank a number of close friends for their continuing moral and emotional support: Kelsi, Frith, Jack, Matthew V, Michael, Joey, Bernadette, Edward, Matthew W, Claire, Nadége, and Zane. I am grateful also to the wonderful staff and students of the English department for their kindness and encouragement throughout the year.

Finally, I would like to thank my former high school English teacher, Amanda Jarden, for both realising and pushing my abilities. Without her encouragement, I would not have attempted to pursue higher education when I did. 


\begin{abstract}
The introduction of printing to England in the late fifteenth century dramatically altered the form and function of the written English language, as the production of texts increased exponentially within a very short time period. This shift from manuscript to print is characterised as the beginning of Early Modern English, when standardisation and modernisation of text began in earnest and neared completion by 1700 . William Caxton, England's first printer and an enthusiast of literature, is credited with making genuine efforts towards 'Standard English' in his short career; his immediate successors, however, are traditionally regarded as reverting to irregular spelling forms and hindering the process of modernisation and standardisation which was slowly developing in the fifteenth century. The aim of this thesis is to examine the language of two of Caxton's successors his former apprentice Wynkyn de Worde, and de Worde's chief competitor Richard Pynson - for signs of modernisation and standardisation within their works. This is achieved through the close study of ten language forms, both morphological and orthographic, between 1490 and 1530 .

Thirty-six texts printed by de Worde and Pynson were selected from a variety of genres, including devotional works, sermons, legal texts, travel diaries, histories, and philosophical works, sourced by Pynson and de Worde from medieval manuscripts, contemporary translations, and original compositions, to represent the work of the two printing houses. For each printer, two ten-page samples of two texts were taken from fiveyear intervals and examined in facsimile, and from this data a number of trends and processes can be identified. Innovative, or modern, variants of the five morphological forms tended to be already common in the first decade of printing, and by 1530 were firmly established, whereas the orthographic forms began to modernise mostly after 1500 , and were less regular than the morphological forms studied. Both morphology and orthography within the texts of Pynson and de Worde show clear development away from the forms favoured by Caxton and the Chancery scribes and towards more modern forms. Textual evidence strongly suggests that this trend was due more to the increasingly modern copy-texts of the works produced, and by extension the spelling practices of contemporary writers and translators, rather than concerted efforts of the printing house towards implementing an orthographic standard.
\end{abstract}




\section{List of Tables}

Table 1.1. Morphology Raw Data $\quad 28$

Table 1.2. Orthography Raw Data pt. 1

Table 1.3. Orthography Raw Data pt. $2 \quad 30$

\section{List of Figures}

Fig. 1.1. Use of hem and them in Pynson and de Worde 33

Fig. 1.2. Use of tho and those in Wynkyn de Worde 35

Fig. 1.3. Use of fro and from in Richard Pynson 36

Fig. 1.4. Use of fro and from in Wynkyn de Worde 37

Fig. 1.5. Use of mo and more in Pynson and de Worde 38

Fig. 1.6. Use of ne and nor in Richard Pynson $\quad 40$

Fig. 1.7. Use of ne and nor in Wynkyn de Worde 41

Fig. 1.8. Overall modernisation of morphological forms in Richard Pynson 42

Fig. 1.9. Overall modernisation of morphological forms in Wynkyn de Worde 43

Fig. 2.1. Spelling of intervocalic /ð/ in Richard Pynson 48

Fig. 2.2. Spelling of intervocalic /ð/ in Wynkyn de Worde 48

Fig. 2.3. Spelling of /g/ in give/again in Richard Pynson 53

Fig. 2.4. Spelling of /g/ in give/again in Wynkyn de Worde 54

Fig. 2.5. Spelling of / $\varepsilon$ : in Richard Pynson 57

Fig. 2.6. Spelling of / $\varepsilon$ : in Wynkyn de Worde 57

Fig. 2.7. Spelling of $/ \varepsilon$ : / in words of OE origin in Pynson and de Worde. 58

Fig. 2.8. Spelling of $/ \varepsilon$ : / in words of ME origin in Pynson and de Worde. 59

Fig. 2.9. Spelling of nasal ME /a/ in Richard Pynson 63

Fig. 2.10. Spelling of nasal ME /a/ in Wynkyn de Worde 63

Fig. 2.11. Spelling of ca. 1500 /o:/ and /u:/ in Richard Pynson. 67

Fig. 2.11. Spelling of ca. 1500 /o:/ and /u:/ in Wynkyn de Worde. 68

Fig. 2.12. Overall modernisation of orthographic forms in Richard Pynson. $\quad 70$

Fig. 2.13. Overall modernisation of orthographic forms in Wynkyn de Worde. 71 
List of Abbreviations

CEEC

$D N B$

Corpus of Early English Correspondence. Ed. Terttu Nevalainen, et. al. Helsinki: Department of Modern Languages, University of Helsinki, 1998.

Oxford Dictionary of National Biography. Ed. H. C. G. Matthew and Brian Harrison. Oxford: Oxford University Press, 2004.

$D O E$

Dictionary of Old English Corpus. Ed. Antoinette DePaolo Healy et. al. Toronto: University of Toronto, 1997, 2007.

EEBO

Early English Books Online. ProQuest LLC, 2003. Web.

EETS

eLALME

The Early English Text Society

McIntosh, Angus, et al., eds. A Linguistic Atlas of Late Mediaeval English. 4 vols. Aberdeen: Aberdeen University Press, 1986, 2014. Web.

eModE $\quad$ Early Modern English

GVS Great Vowel Shift

GW

Gesamtkatalog der Wiegendrucke: Union Catalogue of

Incunabula Database. Staatsbibliothek zu Berlin, 1925-2009, 2014 .

IPA

International Phonetic Alphabet

ME

Middle English

$M E D$

Kurath, Hans and Kuhn, Sherman, eds. The Middle English

Dictionary. Michigan: University of Michigan Press, 1954, 2007.

$N C E$

Marthaler, Berard, exec. ed. New Catholic Encyclopedia. 2nd ed. Detroit: Catholic University of America, 2003.

OE

Old English

$O E D$

Oxford English Dictionary Online. Oxford University Press, 2000.

PresE

Present-Day English

STC

Pollard, A.W and Redgrave, G. R. eds. A short-title catalogue of books printed in England, Scotland and Ireland, and of English books printed abroad 1475-1640. $2^{\text {nd }}$ Edition. 3 Vols. London: The Bibliographical Society, 1986, 1976, 1991.

USTC Pettegree, Andrew et al. Universal Short Title Catalogue.

University of St Andrews, 2014. 


\section{Introduction}

The study of language change in a historical context has undergone a significant transformation in the last thirty years. Recent scholarship is concerned with the social aspect of language change, and factors such as social status, gender, and geographic location are considered in the development of the English language with new interest. As well as this, rapid advances in technology have realised the potential of intensive language studies in a scale which was previously impossible. These developments in both theory and technology are challenging a number of long-held beliefs about the history of the English language, particularly during the Middle and Early Modern periods. Two figures who remain largely unstudied, particularly in light of these new trends in linguistic research, are the early printers Wynkyn de Worde and Richard Pynson. These men were William Caxton's immediate successors and accompanied the printed English text from Middle to Early Modern English in the late fifteenth and early sixteenth centuries, a number of years difficult to define as belonging specifically to either period. The language variation and change, particularly in orthography and morphology indicate that a study of these changes within the context of these two particular printing houses could be of great interest.

The core principle of historical sociolinguistics is that language change is the direct result of the activities of speakers. Language is inherently dynamic, and without an active speech community to maintain the functionality and relevance of such a language, dialect, or variety, it is doomed to fossilise. A number of languages do in fact live on in a sense of suspended animation, existing in literary, political, educational, and religious domains, such as Latin during the Middle Ages (although Latin still underwent a degree of change, particularly in orthography and lexis, after centuries of close contact with vernacular languages [Herren 124-128]) but such communities, both written and spoken, are generally socially, politically, and economically invested in maintaining the status quo. As a result preservation, rather than innovation, is the attitude (whether conscious or not) towards these languages. Languages which express variety, change, and development are represented on a wide social spectrum, spoken in the home, the workplace, and the public domain. This is not a new concept in the field of linguistics by any means, but it was only quite recently that scholars began to make a concerted effort to reconstruct (with as much accuracy as is possible) historical speech communities in an attempt to understand how these social networks influence the direction of language change.

The communities with the most linguistic change were found to be those which experienced rapid social and geographical mobility, on both an individual and a class level (Milroy and Milroy 370). London in the fifteenth century was one such community, and as such, ripe for linguistic change. After the devastating plagues of the fourteenth century, 
the social order, particularly in the provinces, was thrown into disarray. Labourers previously bound to landed gentry were free to seek livelihoods elsewhere, and many rural workers turned to the urban centres for employment (Shaklee 53). London became the indisputable urban centre of England, and a central point of contact with Europe; the exportation of corn, wool, and textiles especially transformed the economy and enticed encouraged internal migration (Conde-Silvestre and Hernandéz-Campoy, Linguistic Innovation 114). Together with the lower class, professional lawyers, clerks, merchants, and other men of business flocked to the city, bringing with them characteristics from their native speech communities. It was inside this melting pot of class and dialect that the beginnings of a variety which has become known as 'Standard English' began to take shape. Although English was not fully standardised until the end of the seventeenth century (Scragg 80; Görlach, Early Modern English 78; Howard-Hill 16), scholars have searched extensively for early attempts at standardisation in the fifteenth and sixteenth centuries in an attempt to trace the development of 'Standard English' in late ME and eModE. As a result of these studies, the notion that there was a single linguistic ancestor of this variety has been thoroughly rejected. Standardisation is no longer seen as a "linear, unidirectional development" - instead, it is now regarded as a set of processes "developing at different rates in different registers" (Wright 6). Its origins can be traced from a number of various dialects, reflecting the changing demographics of London in the fifteenth century.

As the urban population increased, so too did the rate of literacy. Efforts to determine the number of readers and writers, are problematic and the definition of literacy varies from person to person. The actual rate of literacy in fifteenth and early sixteenth-century England is subject to debate; Thomas More's assertion in his 1533 Apologie (the only surviving contemporary 'evidence') that half of England could read and write is considered an exaggeration, and reflects More's social network rather than the state of England as a whole. Without sufficient evidence, it is impossible to fix a solid number with any conviction. Realistically, these figures were probably low - modern estimates place the literacy rate at around ten per cent for men and one per cent for women (Cressy 177), but this was nevertheless higher than ever before. The definition of 'literacy' is one that has changed significantly throughout history as access to reading and writing materials, and the quality and inclusivity of education became widespread. To be 'literate' in the fifteenth century generally suggested a knowledge of literature, history, science and the world. The scarcity and great expense of books, however, meant that fluency of both reading and writing was impossible to maintain on any widespread level, and it was not uncommon for 'literate' people (particularly women), who could read and remember a wide variety of information and narratives, to be unable to write. The female Pastons, for instance had their letters transcribed by a number of scribes, but "were 
literate as readers if not as writers, fully at ease and conversant with the process of creating a text" (Rosenthal 185). Discussion of literacy must take into account the oral communication it "complemented, substituted for, and often competed with" (Briggs 398). The surviving evidence nevertheless suggests a community that had a growing appreciation for and understanding of the written word. The London Chronicle, the Paston, Cely, and Stonor letters, extant broadsheets and advertisements, and records of guilds are all examples of texts written by and for a reading population which even just a century before had been removed from the written word. Book ownership, once limited to the aristocracy and religious orders, became possible for the men and women in service of the "growing royal bureaucracy", the minor gentry, and wealthy merchants, as the price of books declined and living standards and the demand for luxury goods increased (Gillespie 33). For this growing middle class, reading became a necessary skill in order to communicate and share information with their peers, and to further their own careers and social statuses. These comparatively new readers were socially quite distant from the previous noble and ecclesiastical classes. While religious and literary texts still dominated the output of fifteenth-century scribes, there is an influx of books that could not necessarily be considered literature, such as handbooks for hawking and chess, religious and philosophical guides, and conduct manuals. What emerged in the fifteenth century was a society of "practical literacy", where reading and writing was no longer associated only with the church and nobility. This marked a crucial shift in the ideology of writing, and made the development of a vernacular written culture finally possible (Briggs 404).

Although the increase in this "practical literacy" would have in some limited way altered the form and function of English, what truly necessitated further uniformity of the language was the increased "administrative function", identified by Milroy as an imperative aspect of standard, and later prestige, language forms (129). Latin, and to a lesser extent Norman French already occupied such domains in medieval England, their influence visible in the formal English vocabulary of science, law, and government. The most influential study of English dialects in the fourteenth and fifteenth centuries was conducted by M L Samuels, who in his quest to identify the ancestor dialect of 'Standard English' recognised four main types; type I, a Central Midland standard typical of Wycliffite material in the late fourteenth and early fifteenth centuries; type II, the written language of London between 1340-80; type III, "Chaucerian" English which spread through the manuscripts of Chaucer and Hoccleve; and type IV, the language of the English government in the fifteenth century, identified as the 'Chancery Standard' ("Middle English Dialectology"). This type IV is the earliest incarnation of 'Standard English' (since the Norman Conquest) as it is functionally understood today. Although English had some history within the courts and places of business, it was Henry V in 1417 who formally established English as the written language of his own personal letters, and 
by extension the petitions and official documents penned by individuals and institutions (Fisher, Chancery English 5), and the use of English in official documents became an enduring practice, which has since come to be known as the 'Chancery Standard' (although the suitability of Chancery as a title for this new variety has recently undergone scrutiny, the term is firmly established in academic discussion on fifteenth-century language and will continue to be used here). According to Fisher, the adoption of English within this new speech domain instigated a rapid shift in the perception and representation of the language: "The most important development of the century was the emergence of writing as a system coordinate with, but independent from, speech. It is characteristic of all official languages ... that they are written in the same way, no matter how they are pronounced" (Fisher, Chancery English 26). What progressed in the middle of the fifteenth century was a development towards a standardised, 'fixed' form of English, spreading from government officials to the commercial and private communities, and regularisation of spelling and morphology had reached comparative harmony by 1450 (27). The association with economic and political power elevated the cultural status of Chancery English, which was soon adopted by the commercial sector largely outside the immediate influence of local and national government.

In the latter half of the fifteenth century, this new standard of English became equated with prestige, education, and economic and political influence. It is in this period that numerous incipient forms of 'Standard English' emerged in the written correspondence of certain members of society. Social stratification in Early Modern English is classified into four core groups by Nevalainen and Raumolin-Brunberg, and this model has since been adopted by other historical sociolinguists examining the fifteenth, sixteenth, and seventeenth centuries. The first group, labelled the "upper ranks" include royalty, nobility, and the gentry; the second group are identified as "social aspirers" those who were particularly enterprising and had successful careers (examples such as Thomas Cromwell and Cardinal Wolsey are cited); the third group is made up of less successful professionals who were mainly lawyers, merchants, and non-gentry clergymen; the fourth and final group encompasses the non-professional literate population (Sociolinguistics and Language History 58-61.) In their study of fifteen language forms from the late fifteenth to the seventeenth centuries, Nevalainen and Raumolin-Brunberg identify definitive trends of social stratification in language use. The group with the greatest diffusion of new forms was unquestionably the second group of social aspirers. The study concluded that upwardly mobile people are "likely to choose overtly prestigious forms and avoid alternatives associated with low social status" and professionals "often acquired their linguistic models from their social superiors and consequently played an important part in the diffusion of new variants" (Historical Sociolinguistics 152-4). 
These assertions are supported in two other studies of fifteenth-century correspondence. Although there is no explicit sociolinguistic focus, Davis notes in his intergenerational study of the Paston letters that the writers most aligned with the growing standard are not the university men "but rather the courtier and soldier Sir John and his young brother who also became Sir John and the trusted servant of noble families" (130) - in other words, the "social aspirers" suggested by Nevalainen and RaumolinBrunberg as the strongest diffusers of new language forms. A second study of fifteenthcentury correspondence conducted by Conde-Silvestre and Hernandéz-Campoy recognised the significance of contact with the legal profession, specifically by those who used Chancery on a daily basis, in the early individual transmission of new language forms; the clearest early adopters of Chancery forms in the study were not members of the upper gentry, but the lawyers Thomas Mull and Richard Page (Chancery Practices 145). Aside from the professional lawyers, the highest rates of adoption were found in individuals with "high geographical and social mobility", especially the upper gentry and urban non-gentry (148). There is a very strong correlation between individuals and speech communities with upward social mobility, and the early diffusion of Chancery English in the fifteenth century.

The introduction of print dramatically transformed written communication and, by extension, language, in fifteenth-century society, as accessibility to books greatly expanded. The price of a text varied wildly between manuscript and print; an inventory of some fifty books at Oxford in 1483 yielded an average valuation of $5 s .2 d$. (Overty 24), while a typical early printed quarto text would fetch just $4 d$. (Bennett 186). The declining price of books intensified with the exponential output of written material following the introduction of the press. Albinia de la Mare noted "in 1483 the Ripoli Press charged three florins per quinterno for setting up and printing Ficino's translation of Plato's Dialogues. A scribe might have charged one florin per quinterno for duplicating the same work. The Ripoli Press produced 1025 copies; the scribe would have turned out one" (207). It is estimated that Lydgate's Fall of Princes (approximately 180 folio leaves of verse) would have taken several months for a professional London scribe to copy in full; comparatively, Pynson's 1494 edition of the same text yielded 600 copies (Gillespie 65). Books were no longer exclusive objects of luxury, but affordable and available to a wider audience than ever before.

It is in this environment that William Caxton set up his printing press at Westminster in 1476. Caxton was a native of Kent who spent a significant period of his life abroad, and the relative closeness of his printed language to Chancery indicates a conscious effort to align his language towards his anticipated market of the wealthy gentry. As a diplomat and prominent man of business, Caxton enjoyed respectable 
influence within the court and the royal family itself, and it is to this social class he appealed for patronage (Blake, Caxton 80). Caxton's ties to the Royal family were instrumental in the success of his business; his relationship with Margaret of York is well documented (it was she who first encouraged Caxton to complete his Recuyell translation), and Earl Rivers was a key figure in the establishment of the Westminster press in 1476 (87). A large number of his books were commissioned, translated by, or dedicated to noble figures within the court, and his selection of texts was tailored for their literary tastes. Although Caxton was at heart a merchant, who cannily marketed his books and shaped his business around what he thought to be his widest audience, there is nevertheless a perceptible affection within his texts for their literary qualities and refined language, from which he felt his own "rude speche" fell dramatically short. He is in many respects one of the 'socially mobile' individuals responsible for linguistic change, and is consistently lauded as one of the most important figures, not just in the history of fifteenth-century English, but in the language as a whole.

After Caxton's death in 1491 and ensuing years of litigation, the business fell to his former assistant, Wynkyn de Worde. Little is known about Caxton's successor - the earliest English record of his existence is a deed from Westminster Abbey dated to 1480 (Hellinga 131). Several theories on de Worde's nationality have been suggested; it is generally accepted he was born in the town of Wœrth in Alsace (Plomer, Wynkyn de Worde 43), but Hellinga notes the significant circumstantial evidence that ties him to Holland and the Low Countries (135). It is supposed that he travelled to England with William Caxton, or very shortly after, working initially as a compositor and pressman under Caxton's supervision (Plomer, Wynkyn de Worde 44). De Worde's first few years of printing consisted of straight reprints of Caxton's works, such as The Golden Legend, the Polychronicon, and Earl Rivers' translation of the Cordiale, suggesting an initial reluctance to develop the business from Caxton's courtly intentions, although the texts were of a higher quality. In 1500, de Worde moved to a large house in Fleet Street, and fashioned a new symbol for himself in 'the Sign of the Sonne', and "from that time on a radiant sun in his printer's device may signal to us that he had emerged at last from Caxton's shadow" (Hellinga 132). Until his death in 1535, Wynkyn de Worde shifted the focus of the printing house quite dramatically from Caxton's literary foundations. Just as Caxton worked closely with the royal family, de Worde sought favour from the king's mother, Lady Margaret Beaufort, credited as a patron for a number of his texts (Hellinga 158). De Worde is sometimes characterised as a 'people's printer', particularly as his output exceeds that of his contemporaries, with almost 800 texts ascribed to his name. His preference for the small, cheap quarto pamphlet, usually of 24 or 32 pages (Bennett 187), directed his business towards this above-mentioned community of middle-class readers. Wynkyn de Worde ran his business with the very clear goal in mind - to produce, market, 
and sell as many texts as he possibly could, and the distribution of wealth in his will after his death in late 1534 suggests that, ultimately, de Worde enjoyed significant success as a businessman and a printer (Hellinga 154).

Wynkyn de Worde's chief competitor, particularly in the early years of his career, was Richard Pynson. A Norman by birth, Pynson attended the University of Paris in 1464 (Plomer, Wynkyn de Worde 109), but nothing else is known about his early life. Pynson was a relative newcomer to London upon Caxton's death, originally publishing reprints of Caxton's works, but quickly expanded to include Law-French, after the death of William de Machlinia left a vacuum of supply (Duff, Book Trade 97). Pynson easily cornered this market with his Paris education and Norman background, and he maintained a steady output of legal texts throughout his career. Pynson also printed for schools and the clergy, but his most common works were still for the average reading public. His most prominent role was that of King's Printer, a title earned in 1506 (Hellinga 114). Pynson is generally considered to be more cautious than his chief competitor. Less of a 'people's printer' than de Worde, Pynson tended to attach himself to texts which assured him a steady stream of income, rather than investing in possible risk. He strove to maintain a balance between various groups of clients, spreading his texts across English, French, Latin and, in 1524, Greek (Hellinga 117, 130). One reason for this is his lack of venture capital; unlike de Worde, who inherited a fully-functioning printing house with an existing clientele, Pynson had to fund everything from the ground up, and to pay for this, entered into complicated deals with potential financial supporters, a number of which had to be resolved in the law courts (Hellinga 124). Activity in Pynson's house declined in the last year of his life, presumably with his ill health and old age, and he died in November 1529.

One criticism of Pynson and de Worde is that they are the 'wrong' sort of characters to fulfil the role of linguistic reformer, and the years of early printing are seen in some way as a 'lost opportunity' to enforce an early standard, mainly because neither man was particularly literary or a native speaker of English. Such an opinion imposes a very narrow view on how printed texts are constructed and read. Caxton, traditionally seen as the first printer to promote an early English standard (Scragg 74; Hellinga 117), did not single-handedly write (or translate), compose, edit, and print every text that he sold. The internal network of the printing house and the wider community in which it stood shaped the text in a number of ways. What made Caxton a strong agent of language change was the social and political influence he held in London and the Court. This established a loose-knit network of social ties through which an individual language variety is both influenced and then diffused (Millar 54, 160). Caxton, despite relatively humble beginnings, was a highly successful businessman and diplomat with ties to the royal family, who travelled throughout the Low Countries on business and on errands of 
government for several decades in the fifteenth century, and also had geographical and social mobility, identified by sociolinguists as traits common to figures with the strongest language change (Labov 286). While Caxton sought a medieval and courtly audience, de Worde and Pynson strove to expand their businesses and sell their wares to new clients, from the traditional king and court, to professional lawyers and schoolmasters, and to the middle-class freemen and apprentices.

While it is impossible to completely reconstruct the social networks of the early sixteenth century, observations can be drawn from the evidence de Worde and Pynson have left behind. From 1500 onwards, there is a considerable rise in the number of texts printed at the explicit command of wealthy and influential patrons, such the royal family. These patrons include Lady Margaret Beaufort (a major patron of de Worde), Henry VII and his son Henry VIII (a privilege enjoyed by Pynson as the 'King's Printer'), Catherine of Aragon, Bishop Richard Foxe, and Thomas Howard, 3rd Duke of Norfolk (among others), all of whom exercised significant political power in the first half of the sixteenth century. Another social factor to consider is the wider, inclusive network of professional writers, clergymen, and businessmen, whose contribution to the text cannot be understated. These men were open about their involvement with the printed word, and there is a marked increase in how often they are referenced and named within the texts themselves, in comparison to the English writers of the earlier generations (Gillespie 30), and it is from this newfound confidence that we can draw a sharper picture of just how far the textual community extends beyond the immediate printing house. Many source texts were in Latin, French, and less frequently German and Italian. While Caxton would happily translate such texts himself when he could, Pynson and de Worde instead turned to educated writers for this work, again, chiefly after 1500. Such translators include Henry Watson, Alexander Barclay, Thomas More, John Ryckes and Thomas Wyatt. Barclay, More, and Wyatt in particular are respected writers in their own right, and their employment gave Pynson and de Worde the opportunity to produce translations which were generally of high quality and accuracy. As well as translated works, there was an influx of original material across a wide range of genres, including some written by the above mentioned translators and noble patrons. Such authors include the schoolmaster John Stanbridge, St. John Fisher, the librarian Thomas Betson, Robert Whittington, John Skelton, Stephen Hawes, Sir Richard Guildford, Simon the Anchorite, and Henry VIII. This long list of authors, translators, and patrons ranges from middle-class professionals to the King of England himself. From this evidence, it can be asserted that both Pynson and de Worde (who of course knew each other quite well, as business rivals and neighbours) had wide, loose-knit social networks across a number of speech communities. I believe there is no reason why a similar profile cannot be attributed to Richard Pynson and Wynkyn de Worde as there is to William Caxton. Both printers had the geographical 
mobility, the broad social network, the contact with figures of significant political and social influence, and the economic means to be considered as agents of language change and standardisation in the late fifteenth and early sixteenth centuries.

What all three men share is that each was the head of a small business, rather than the authorial hand behind every text, and this of course has a distinct impact on the language of the text. The works produced by the houses of Wynkyn de Worde and Richard Pynson themselves account for two-thirds of available books in the English market from 1500-1530 (Steinberg 106). Although his wealth had somewhat eroded after a long history of litigation, Pynson was nevertheless still able to leave "considerable" property in Chancery Lane and Tottenham (Duff, Book Trade 127), and from the contents of his will is considered "prosperous" (DNB "Pynson, Richard"). Wynkyn de Worde's net worth was valued at $£ 20111 s .1 d$. (Erler 115), a considerable sum which was divided handsomely between a large number of both current and former associates and servants (Hellinga 155). Printing in the fifteenth and early sixteenth century was a volatile and uncertain market, with many printers in the constant shadow of bankruptcy (Bühler 57). Evidence indicates Pynson and de Worde thoroughly understood the financial process of printing, and were efficient and successful businessmen. They knew not only how to operate a printing press, but how do so productively.

The act of printing itself, namely the mechanical process of type-laying has significant influence on some aspects of language (Howard-Hill 25). We are aware of the basic process: the text is first 'composed', with tiny letter-shaped tiles arranged backwards into words and sentences on the compositor's stick and then transferred line by line (with 28-32 lines being common for an early English text) to the larger page, a fastidious and repetitive process. Each page is checked by a proofer or editor, and then sent to the printing press to be duplicated, after which it is bound and sold. There is essentially no contemporary evidence on the physical process of the printing house - the earliest illustrations date to the late sixteenth century, and the first detailed description of the textual production in English is contained within Joseph Moxon's Mechanick Exercises, printed in 1683. However a number of respected bibliographers agree that the core method of printing experienced little real change between the fifteenth and early eighteenth centuries (McKenzie, "Printers of the Mind" 51; Twyman 38), and we can take Moxon's incredibly detailed narrative as, for the most part, a reliable account of the mechanical process of printing in the early sixteenth century. Most relevant here is Moxon's description of the compositor and editor, the two figures responsible for the textual construction of print, which is the focus of this study.

"A good Compositer," Moxon writes, "need be no more than an English Scholler, or indeed scarce so much". He "is strictly to follow his Copy, viz. to observe and do just so 
much and no more than his Copy will bear him out for; so that his Copy is to be his Rule and Authority." (197-8). It is beyond the authority of the compositor to alter the text, or make any emendations; the compositor's most common changes from the copy-text were the simple errors (i.e. when a letter such as $n$ is turned upside down, or similar letters like $b$ and $d$ confused, or when tiles are arranged incorrectly to form a word) introduced in transcription and type-setting. Moxon's description of the ideal corrector, or proofer, of the text is even more particular: "He ought to be very knowing in Derivations and Etymologies of Words, very sagacious in Pointing, skilful in the Compositers whole Task and Obligation, and endowed with a quick Eye to espy the smallest Fault" (261). The process is equally painstaking: The compositor carries this first proof to the editor, and a reader, appointed by the master printer, "Reads the Copy to him, and the Correcter gives attention; and at the same time carefully and vigilantly examines the Proof, and considers... any error that may through mistake, or want of Judgement be committed by the Compositer" (261). The proof-sheet is returned, reset, and corrections made. The editor, or proofer, was probably more vigilant in correct orthography and overall precision in Moxon's day than in the early sixteenth century - the number of faults in late seventeenth-century texts are certainly lower than in the works of Pynson's and de Worde's houses. The perception of what made 'good' English had expanded beyond lexis and style to include spelling and grammar, which by the 1680 s was far more fixed than in the 1490-1530 period.

Understanding the printing process, which has no doubt been refined over the course of almost two hundred years, McKenzie concludes that extant evidence of correcting and proofing in earlier texts suggests that this process was largely retained: "The procedures have always been the same - only the methods of recording them have differed" ("Printers of the Mind" 49). There are some recorded differences in spelling of the printed text in relation to the original from which it has been set; M L Samuels notes in a comparison of Sir Thomas More's autograph letters and the printed texts that printers preserved some authorial spellings but replaced others by their own ("Spelling and Dialect” 44), Caxton's editing and respelling of texts such as Le Morte D'Arthur is well documented (Blake, Caxton 187), and Horobin records a number of respellings by Pynson from the copy-texts in his fifteenth-century editions of Chaucer (Horobin 256). This indicates that changes, whether intentional or unconscious, were being made at either the compositor's or the proofer's level. While some changes can be attributed to the necessity of setting a line of text, by adding or removing redundant letters, what is uncertain is the motivation and nature of these other changes - whether it is the implementation of a system or an unconscious slip into individual spelling habits, and whether the printinghouse intentionally guided such spellings towards a dialect considered 'standard' or 'prestige'. 
Of course, neither printer operated their business single-handedly. Howard-Hill claims that "the personnel consisted of a master printer, journeymen printers (compositors or pressmen) and apprentices", and in larger houses (such as those owned by Pynson and de Worde) "a warehouse keeper and sometimes boys to aid the pressmen" (19), although this is not sourced by primary evidence. Records of the Stationers' Company, dating from 1562-1640 (which serves as a reliable estimate for the printing houses in the early sixteenth century, before the printing and bookbinding trade became more regularised), state that 3,780 apprentices came from provincial areas outside of London and Westminster, indicating wide geographic variation (McKenzie, "Stationer's Company" 298). From extant documents, we are able to identify a number of individuals employed under Pynson and de Worde. The two most famous employees were Thomas Berthelet (a former assistant of Pynson) and Robert Copland (a former assistant of de Worde), both of whom flourished as printers in their own right. Berthelet was in Pynson's service at least as early as 1520, and became a self-employed printer in 1528 (Duff, Book Trade 12). Upon Pynson's death, he was appointed the King's Printer, and is considered "one of the most distinguished and prolific printers in England in the sixteenth century" (Hellinga 185). Copland, meanwhile, is recognised not just as a printer, but as an excellent French scholar, translating many texts for de Worde from 1508 onwards and composing a number of verse pieces for the printing house. (Duff, Book Trade 32). Along with these two main assistants, other printers are linked to Pynson and de Worde: John Butler, John Byddell (steadily successful printers in the 1530s and 1540s [Duff 19-20]), John Haukyns (who completed Pynson's unfinished printings on his death [Duff 68]), and Henry Watson (who also translated a number of books for de Worde as well as working as a printing house assistant [Duff 166]). Another eight apprentices are mentioned in Pynson's and de Worde's wills (Erler 118-21), some with considerable bequests of up to several pounds. While we do not know exactly who performed what tasks, it is reasonable to assume that these men above the rank of apprentice, particularly those involved in translation, would be those responsible for composing and proofing. These former assistants and servants are educated, skilled men who evidently had competent knowledge of English, and their contribution to the printed text should not be undervalued or ignored.

There is without a doubt a number of factors to consider when studying the language of a printed text which are not apparent in scribal manuscripts, with different concerns, and functions. The printing house is a business, and in the cases of these two printers, a successful business, run by a number of literate men. The text must be considered as a heterogeneous work, rather than the product of a single hand; the nature of composition can reflect interesting patterns in the variation of certain spellings, and the rate of standardisation traced more definitively in a wider social context than a private letter or manuscript. 


\section{Review of Scholarship}

Scholarly interest in early printed material developed in earnest with the nineteenth century, as Victorian academics began to research and catalogue the growing collections of surviving texts in both university libraries and private collections. Their attention was drawn primarily to the 'human' aspect of early printing - histories and biographies of the printers and the society in which they lived were often more popular than linguistic or even literary analysis of the texts they produced. Caxton was obviously the most studied of the early printers, being both the first to bring the press into England and the first 'English' printer. Particular attention towards Pynson and de Worde is scattered throughout the scholarship of early English printing, and is for the most part, critical. The foreign printers are compared to Caxton, a native Englishman and enthusiast of high literature, a standard which is impossible to meet.

William Blades, in his seminal Life and Typography of William Caxton mentions Pynson only in passing, and his evaluation of Wynkyn de Worde, both as Caxton's assistant and a printer in his own right, is heavily negative. He rubbishes de Worde's proem in his Bartholomeus text as "doggrel" (55), and notes that "to a general carelessness about names and dates, Wynken de Worde added a negligence peculiarly his own" (56). Blades is particularly acerbic in his final summation of de Worde's spelling and general quality of text: "If accuracy of text were to be taken as the standard, independently of excellent workmanship, it is to be feared that Wynken de Worde would take a very low place in the rank of his contemporary typographers" (57). This is a view perpetuated by the most influential scholars of early printed English in the nineteenth and early twentieth centuries. It is unsurprising that the negativity towards the foreign Pynson and de Worde are sharpest at the height of British imperialism. When scholars care to mention Caxton's immediate successors, it is with sneering disapproval: Henry Lathrop dismisses the works of Caxton's contemporaries as "simply crude" (28). While Henry Plomer praises the craftsmanship of Pynson and his wide use of European types, (Wynkyn de Worde 149) he begrudges de Worde's work as "often spoiled by stupid mistakes and carelessness in both composition and press-work" and claims the printer "had no literary tastes" (Wynkyn de Worde 101). Plomer criticises Wynkyn de Worde most sharply in his biography of Caxton, where he writes "Wynkyn de Worde was never at any time what would be called a good printer. He was careless and slovenly, and where such faults show themselves in Caxton's books, we may feel sure that they were due to Wynkyn de Worde rather than his employer" (Caxton 166). With this fixation on the early printers as historical figures, little attention is at first paid to the language within the texts. Much is made of Caxton, and no early twentieth century book on early printing in England is found without a reverent appreciation of Caxton's 'quaint', 'delightful', and 'plain' English. Such discussion is largely superficial, and there is almost nothing of note to be found on Pynson or de Worde's 
language at all. Scholars became interested in the literary and aesthetic quality of the printed works - content matter, illustrations, and cleanness of print - rather than the linguistic. It is very likely that the negative reaction to de Worde and Pynson by scholars such as Blades, Plomer, and Lathrop shaped the perception of these foreign printers throughout the twentieth century, as studies on language and the origins of 'Standard English' gained popularity.

Norman Blake discusses the issue of Caxton's English (with some attention paid to Pynson and de Worde) at length in several of his works. In his assessment of Caxton's spelling, Blake concludes that the language in Wynkyn de Worde's books is both more modern and standard than his deceased master's and suggests that "we may have been unjust in our estimation of de Worde in the past" ("Reynard" 76). Even after making this concession, Blake attributes much of this standardisation not to the master printer, but to an anonymous compositor, as "de Worde employed English compositors whereas Caxton employed de Worde as his principal assistant" (Caxton, 175). Blake's treatment of Pynson's language is much less detailed - his only evaluation of note is found in his longitudinal study of Reynard the Fox (a text printed by Caxton in 1481 and 1489, Pynson in 1500, de Worde in 1515, and Thomas Gaultier in 1550), where he concludes that Pynson is much less inclined to modernise the orthography of his source texts (76). Blake's hypothesis is the most credible to those of the mid-twentieth century academics, as it is the only one to include a detailed textual study. But this, however, is limited to a handful of reprints and is an incomplete representation of the printing houses themselves. Donald Scragg holds an entirely different opinion to that of Blake. He claims that "neither Caxton nor any of the other successful early printers was fitted by background or outlook for the role of linguistic reformer" (66) and "it was not to be expected that de Worde, an Alsatian by birth, or Pynson, a Norman, would make any major contribution towards the stabilisation of English spelling" (67). The press is seen as an initial disruption to the process of standardisation, undoing the careful work of the professional scribes.

In the 1980 , two figures draw evidence from various fifteenth-century sources in order to form careful observations on the language of early printing. The first is Norman Davis with "Notes on Grammar and Spelling in the Fifteenth Century". Drawing from texts by Stephen Hawes and Alexander Barclay, Davis reconstructs the typical orthographic and morphological conventions of the period. With his attention focused on the details of language, Davis refrains from drawing any categorical conclusions on the spread and nature of such changes, and states quite boldly that "long before the works of Sir Thomas More... the boundary between 'Middle' and 'Modern' English had been decisively crossed. Exact dates in such matters are clearly unattainable" (493). The reluctance to date any changes with certainty is a trend reflected in almost every scholarly discussion of language 
and literature in the fifteenth and early sixteenth centuries. The most extensive study of fifteenth-century English is John Fisher's Anthology of Chancery English. Fisher's ambitious survey of extant Chancery records both affirms popular claims with enumerated evidence, and disproves a number of accepted hypotheses on the conventions of spelling and language change in the Chancery period. What Fisher traces is a gradual development in orthography from the phonetic roots of Middle English to a system independent of speech, and he is reluctant to assign the systematic regularity to Chancery English with the same enthusiasm as Donald Scragg. The relationship between Chancery and Caxton is explored by Fisher in a later study, with direct response to the claims made by Blake and Scragg. With his careful reminder that "Chancery never achieved anything like absolute uniformity in its orthography" ("Caxton" 166), Fisher identifies an impressive 86\% likeness between Caxton and Chancery forms. He concludes "Caxton employed, and therefore transmitted, essentially Chancery forms from the time he began to publish until the end of his career, with no perceptible drift toward more modern or more regular forms" (167) and "Caxton's place in the history of the development of standard written English must be regarded as that of a transmitter rather than an innovator" (168). Although there is no mention of de Worde and Pynson, Fisher's work has been influential by its sheer scope, detail, and generally excellent reception.

Recently, however, the Anthology has been heavily criticised by Benskin as being "riddled with mistakes" (5) and "inaccurate scholarship" (21). Benskin claims the actual standard of spelling within the Chancery documents was "more complex and less determined than it has sometimes been made to appear" (36). The editorial inaccuracies reported were emphasised as historical and geographic problems - issues of dating and cataloguing of documents, and identification of Chancery hands - rather than inconsistencies of transcription. Benskin refers to Matheson's review of the Anthology, which reports 76 errors in 13 texts. While an alarming number, it must be stated that the vast majority of errors are purely graphemic, and appear to stem from a misreading of the script: whiche for whuche, and tat for pat, for example, (Matheson 648), and only one of the ten language forms within this study was identified as being transmitted incorrectly (nasal $<0>$ and $<\mathrm{a}>$ ). Despite these misgivings, Matheson concludes the study is a "valuable" collection (650). Benskin's chief concern is with the distortion of data, particularly in the Signet letters of Henry V, propagating an ideology which is not existent within the collected forms (Benskin 21). Numerous studies of mid-fifteenth-century English reveal tendencies towards trends and forms (particularly by the upper classes) propagated in the Anthology (Conde-Silvestre and Hernandéz-Campoy, Chancery Practices 145, 148; Nevalainen and Raumolin-Brunberg, Historical Sociolinguistics 68), suggesting that while some of the more evaluative assumptions of Fisher's can be 
challenged, the general concept of Chancery is still sound, and the Anthology should not be discarded from the slim library of scholarly texts on fifteenth-century English.

After the 1980s, attention towards the early printers and the issue of transition from Middle to Early Modern English shifted once more, and instead of detailed books on the subject, discussions on language change were confined to short studies on the development of particular forms, or in general studies of historical English. From these various studies come several attempts to sketch the transitional period of the turn of the fifteenth century with a greater detail, although efforts to pinpoint the actual point of development to Modern English is still far from precise. Manfred Görlach draws his conclusions largely from previous studies, but supports these with data gathered from contemporary sources (largely literary texts), and attempts to fix rough dates for a number of changes in the development of 'Standard' English during the sixteenth century, such as the rise of the <ea> spelling and the decline of weak -en verb endings (Early Modern English 46, 90). His evaluation of the contribution of print to these developments is critical, and he claims "the orthography of early printing represents a backward step when compared with the established conventions of chancery English" (The English Language 24). Vivian Salmon writes of the "irregular" orthography of both Pynson and de Worde, and an overall lack of interest towards standardisation in the early sixteenth century, but also admits an "absence of overall analyses of orthographic developments in various sixteenth-century printing-houses". Her closest contemporary evidence is the works of John Hart, writing some twenty years after de Worde and Pynson had died. (24-5)

Similarly, when discussing the development of 'Standard English', Nevalainen and Ingrid Tieken-Book van Ostade refer largely to the works of Blake, Fisher and Scragg, repeating Blake's claim that Pynson and de Worde could not be expected to direct language towards regularity (289), but paradoxically also note the importance of early printers in the regularisation of English spelling. Christopher Upward and George Davidson also refer to Fisher and Scragg in The History of English Spelling, concluding the early printers were extremely irregular in their language forms, and established a standard very "gradually" (84). Another study which pays some attention to Wynkyn de Worde and Richard Pynson is Lotte Hellinga's William Caxton and Early Printing in England. Hellinga investigates the careers of Pynson and de Worde individually, examining the characters of the printers in the historical context of early sixteenth-century England. With a chief focus on the cultural, historical and literary implications of the early printers, Hellinga concludes "the development of English continued in print. Caxton's immediate successors, however, none of them native-born English speakers, slowed this process” (113).

Finally, the development of electronic corpora in the 1990's and beyond (discussed in further detail below) has realised the possibility for analytical studies with a statistical 
base on a much broader scope. These studies, both on fifteenth and sixteenth-century English as a whole, and in particular the texts of Caxton, Pynson, and de Worde, both prove and discredit a number of twentieth-century claims on language change which up until this point was largely conjecture. José Gómez-Soliño’s study of several morphological forms in Caxton's printed works concludes that standardisation of language is not a process Caxton consciously assumed (108). Simon Horobin's orthographic study on the fifteenth-century printed editions of The Canterbury Tales drew similar conclusions, extending his analysis to texts printed by Pynson and de Worde. He concludes that de Worde "made few changes to Caxton's practice and his spelling system is largely that of Caxton with slight modifications in the direction of the standard" ("The Canterbury Tales" 256), and while "de Worde's text does reveal the introduction of standardised spellings not recorded in Caxton" (Chaucer Tradition 85), it is Pynson's edition which sees "a more conscious move to the consistent replacement of 'Chaucerian' and 'colourless' features" and "the role of Pynson in this process should be given greater consideration" ("The Canterbury Tales" 257). Meanwhile, a morphological study by Hanna Rutkowska on The Kalendar of Shepherds, published nineteen times between 1506 and 1656, draws an entirely different conclusion. Rutkowska claims that de Worde "merits special attention for his efforts at the regularisation of spelling," and his "overall consistency deserves great respect and is a proof of his professionalism" (22). Both studies consisted of reprints of the same text, with only one or two examples of each printer. Finally, Mark Aronoff, in a study of de Worde's orthography across a handful of texts printed throughout his career, concludes that while Caxton's orthography is indeed irregular, de Worde "has a regularity that cannot be found in any other English printer's work for almost a century" (72). Aronoff praises the "systematicity" of de Worde's orthography, and suggests "its persistence through verse and prose of a period of close to twenty years points clearly to the conclusion that what we have here is not the world of a single compositor but rather the house style of Wynkyn's press" (85). What is most interesting is how the perception of these early printers differs among the three studies. De Worde, in particular, is labelled as both an echo of the irregular Caxton and a champion of regularisation. These new corpusbased studies, short and contradictory as they may be, are nevertheless exciting challenges to the traditional scholarship of the twentieth century.

What is clear from this overview of academic study is that the initial evaluation of Pynson, and in particular, Wynkyn de Worde, is heavily negative, and this interpretation remains largely unchallenged for the better part of a century. The most influential twentiethcentury academics (with the exception of Blake) pay insufficient attention to Pynson and de Worde, and arguments are generalised to cover 'the early printers' as a single entity, despite obvious differences in age, style, linguistic background, and the time span of their careers. The only studies with significant evidence with a specific focus on Pynson and de 
Worde, such as Blake's 1965 analysis on Reynard the Fox and the later studies by GómezSoliño, Horobin, Rutkowska, and Aronoff, draw conclusions entirely at odds with the popular opinions expressed by Scragg and Fisher, and these statistical analyses in themselves are contradictory and limited in scope and evidence. What follows is an attempt to put at least some of this confusion to rest, through a study of the morphology, orthography, and phonology of texts throughout the careers of Pynson and de Worde, and an attempt to understand the variation and change of this language to conclude to what extent two specific printers did in fact advance or restrict the emerging forms of early sixteenth-century ‘Standard English'. 


\section{Methodology}

"Historical linguistics," writes Gabriella Mazzon, "is a domain not of smooth and neatly-shaped S-curves, but of spiky and irregular landscapes" (56). As with many aspects of social science, linguistics frequently does not 'behave' in a way that conforms neatly to theories on variation and change, and the method of collection and analysis is ultimately influenced by the nature and volume of extant data. Some dialects and languages have millions of surviving texts from which to draw evidence, some a few thousand manuscript pages, and some exist only in phonetic and grammatical reconstructions from attested daughter languages.

The value of surviving written texts as evidence for contemporary language dialect and variety is an issue of some contention. Milroy, the most vocal enthusiast of social-based historical linguistics, endorses the use of written texts and writes that variation in spelling should be investigated, to see if it can help identify trends occurring in spoken English at the time (134). Romaine echoes this sentiment, saying "the written hand shows regular variation in orthographic symbols which is conditioned by context in the same way that the spoken language displays allophonic variation" (16). Lass, on the other hand, cautions that much surviving textual data is second-order and "less trustworthy than the results of standard linguistic reconstruction" (Historical Linguistics 102). The danger in gathering 'bad' or incorrect data when studying written texts arises largely from the form in which the text is presented; edited texts must be regarded not as direct access to the original material, but rather a communicative link, and so the validity of close details must be treated with caution. Editions with normalised or modernised spellings are essentially worthless in the study of phonology and orthography, and can compromise morphosyntactic analysis. The 'best' written data are from direct access to, or facsimiles and very careful diplomatic transcriptions of, the historical texts themselves.

The collection and analysis of language data is dependent on a number of factors, such as the scope and aims of research, and the amount of extant material available. A study of English over two hundred years, for example, will require a methodology vastly different to an analysis of an individual speaker in the course of a decade. For longitudinal linguistic studies, the quantitative method is adopted by most scholars; the focus is on objective, reliable data, collected from a large number of sources, with attention paid to variables and generally statistical approach (Neuman 13). Quantifying data is necessary for anyone who wishes to make accountable statements about the distribution of language forms - in essence, to test the validity of theoretical claims in a 'real-world' setting (Milroy 77). Historical language change in 'real time' is best traced through a large corpus of material that covers a long chronological period, and such studies inevitably focus on trends and large-scale developments of language forms, instead of the minute details. 
(Nevalainen and Raumolin-Brunberg, Historical Sociolinguistics 53). One study in historical English is the University of Helsinki's 2.7 million word CEEC, electronically compiled from edited letters of 778 informants, between c.1410 and 1681. The compilers warn that while the corpus is reliable in the study of lexis and pragmatics, aspects such as orthography and phonology are only valid when studied from original manuscripts (44). At the other end of the scale, micro-level studies which examine the linguistic behaviour of individuals reflect the diversity of a single speaker and the finer aspects of language change in 'action', such as Mel Evans' study of the language of Queen Elizabeth from a selection of her authorial letters (totalling 22,424 words), including an in-depth analysis of her spelling practices (Queen Elizabeth I). The methodology of my study is an attempted marriage between these two research procedures. The period in question barely pushes generational boundaries, unlike numerous larger studies, which examine language change across a century of more (particularly the CEEC studies and Rutkowska's analysis of the Kalendar texts). Nor is it limited in scope to simply a decade, or a single text or speaker over a relatively short period of time (such as Blake's study of Reynard, or Horobin's study of Chaucer's works in 1480-1500). I am studying two separate printing houses over a reasonably long period of time, and the sort of in-depth, exhaustive study conducted by Evans, or the selective analyses of Blake and Horobin, are both unsuitable for the scope of this thesis. I chose to study a general representation of Pynson and de Worde's works, rather than a detailed selection of several key texts. This method is more akin to sampling than an exhaustive analysis, in line with my aims of identifying trends over the course of forty years. However, the pool of data is still enough for the idiosyncrasies of individual text to shine through, an aspect of historical language study which often appears to be ignored (Mazzon 56).

As the strongest criticisms of Pynson and de Worde are directed mainly at 'irregular spellings', orthography is an essential aspect which requires analysis. Electronic corpus studies, such as the $C E E C$, were unsuitable for this study. Facsimiles of the original printed material were gathered from $E E B O$, and data collected manually, through extremely careful reading and notation. I analysed texts from almost the entirety of the printers' careers - from the first full year of printing in 1493, to 1530 (by which time Pynson had died and could no longer serve as a comparison with de Worde, who continued to print until 1534). To cover this period, I selected two texts from each printer over five-year intervals, with nine divisions between 1490 and 1530, a total of thirty-six from which to draw samples. Referring to each text by title or incipit quickly becomes wordy and confusing, and so in the interests of simplicity, I have instead designated the texts within each year as Text A or Text B, with full bibliographic information in the appendix. The parameters for text selection appeared broad; the works had to be predominantly English, at least ten pages long, and contain a basic narrative (this 
discounted material such as grammars, schoolbooks, and cookery books which are often little more than lists of instruction on a page). This seemingly open set of criteria proved to be more defined than initially thought, and a number of small caveats had to be made. I included poetry only when it was unavoidable (as the requirements of rhyme and metre can have significant impact on the spelling of lexical items), and works by Chaucer and Lydgate were deliberately excluded, as such works already form the basis for almost every existing language study on Pynson and de Worde, and the spelling of such texts is atypically conservative, preserving the archaic spellings due to the authors' high esteem. The five-year intervals are imperfect, as it was sometimes difficult to find two suitable texts within a single year. In these cases, a text was selected in the year before or after (say, 1516 instead of 1515), but for the purposes of consistency and brevity will be considered as part of the five-year intervals. The most difficult period of selection was the Pynson 1530 texts; production in the house had declined dramatically in the last two years of his life, and a selection of a 1527 text had unfortunately had to be made. These texts ranged from sixteen page pamphlets to large works of 3-400 pages in length. I selected ten pages (totalling approximately 5000 words) from each text, at reasonably regular intervals (with some concessions for paragraphing and cleanness of text), generating a corpus of approximately 90,000 words for each printer, totalling 180,000 words - twice the content of the Chancery documents $(89,500)$, and three-quarters of the Paston letters (approx. 250,000 words).

From these 36 texts, I attempted to draw a cross-section of printed material representative of the printers' general output of relevant texts. This variety included texts with ME or Classical sources, contemporary works, translations, literary texts, devotional works, sermons, political, legal, and historical texts, travel writing, and other interesting miscellanea. I feel this is a more fruitful analysis than the perhaps more obvious method of studying the language variation and change of several popular texts throughout the selected period. Two factors motivated this decision; Firstly, a general cross-section is a more accurate depiction of the kinds of material requested, printed, distributed, and consumed by Pynson, de Worde, and their patrons and readers. Neither printer relied entirely on reprinting a handful of selected works, as evidenced from their diverse total output (Hellinga 117, 139, 150). The intended audience frequently varied from text to text - the legal professionals, the courtly audience, the middling classes, the social aspirers, and the clergy all had specific tastes, and very few single books were likely to be read on every level of the social spectrum. Choosing, for example, only the poetry of Chaucer, or the sermons of Fisher, or devotional texts, limits not only the range of works available for analysis, but both the textual representation of the printing houses themselves, and indirectly, the intended audience receptive to the language within the printed works. Secondly, on a purely technical level, the texts themselves can significantly skew the 
results of collected data - a lack (or conversely, an overabundance) of relevant forms and lexical items can hamper the quality of the analysis, and if this is repeated across reprints of the same texts, the issue is compounded. I found, for example, that the occurrence of nasal <a> in Pynson's print of Henry VIII's 1516 statutes of parliament was three times higher than any other text, due to the intense repetition of land(e) and hand(e)s ('of the kynge') within the property laws, and one text (de Worde's Myracles of Oure Lady) had three editions conveniently printed in 1495, 1515, and 1530 and is an excellent opportunity to study how reprints affect language. All three texts, however, had only a few examples of several studied forms - a deficiency tracked through all three books. By selecting a range of different texts, I am reducing this effect.

The number of individual language changes recorded, discussed and evaluated in scholarly discussion on the language of the fifteenth and sixteenth centuries guaranteed a long list of possible forms I could study. Preference was given to forms which had identifiable $\mathrm{ME}$ and eModE variants, were found with reasonable frequency in most texts, and could be categorised and displayed in an accessible format. This turned out to be quite a restrictive set of constraints, and several shifts which appear popular in language discussion of the transitional period were regrettably excluded. Two forms simply did not have enough data to make any detailed and quantified observations. The first was the weak \{-en\} verb ending (such as bounden and oughten), a Midland inflection (Lass Cambridge Vol. 3 162) which vanishes at some point in the sixteenth century. It is a "conservative tendency" in the Chancery documents (Fisher, Chancery English 45), and Barber writes it is "largely displaced" in the standard language by 1500 (170), although Lass claims the form survives as late as 1550, and occurs very occasionally in authors such as Surrey, Wyatt (who features in this study) Spenser, and even Shakespeare, mostly as deliberate archaisms or "Chaucerisms", used to imply rusticity (Cambridge Vol. 3 165). It would have been interesting to examine the decline of the $\{$-en $\}$ ending, but the few instances were so scattered and rare that it was impossible to draw any decisive judgements. Another attractive form to study was the rise of the $<\mathrm{dg}>$ spelling at the expense of $<\mathrm{gg}>$ and $<\mathrm{g}>$ for $/ \mathrm{d}_{3} /$ (found in judge and knowledge), a fifteenth-century development (Scragg 51) that became popular in eModE (Upward and Davidson 118). With an average of 2.5 examples per text, there was simply not enough data to quantify statistically significant results. A third element, the decline of the causative do construction which has puzzled academics for decades, could not be studied because I was unable to distinguish any incontrovertible examples of the form within the sample texts. While absence of evidence in itself may suggest the weak $\{$-en\} ending and causative do may be relict forms or even lost, it is difficult to argue without the authority of a much larger study. 
Despite these failures I managed to identify eleven language forms, both orthographic, phonological, and morphological, that fit the criteria for analysis. These forms are divided reasonably cleanly into two categories; morphological (which contains hem/them, tho/those, ne/nor, and fro/from and mo/more), and the orthographic (the variant spellings of the phonemes PresE intervocalic /ð/, PresE /g/ in give/again nasal $\mathrm{ME} / \mathrm{a} /$, closed monosyllabic ME /ع:/, monosyllabic ca. 1500 / :/, and monosyllabic ca. $1500 / \mathrm{u} /$ ). The definition of the second group as 'orthographic change' is a matter of necessity rather than technical accuracy; the changes involved are phonological as much as they are orthographic, and the role of, and interaction between both processes will be discussed. The ability to precisely determine phonological change without spoken evidence is generally difficult, and orthography seems the most appropriate general label to give these ongoing changes. As well as a study of the forms in the works of Pynson and de Worde, I consider how each spelling appears in fifteenth-century texts, and briefly examine the development of the form and its variant spellings throughout $\mathrm{OE}$ and $\mathrm{ME}$. This background information sheds light not just on the detailed and often problematic linguistic history of each form, but how this emerging standard reflects the English language on a national level, examining the relationship between natural phonetic and morphological change, language contact, and social diffusion.

The presentation and processing of data is important, and the most appropriate and efficient way to do so varies frequently from study to study, particularly in recent years. Studies such as those conducted by Blake, Aronoff, and Horobin simply present raw numbers in a simple table, if at all. Attempting to use raw figures over such a wide range of data is not only laborious and confusing, but can also be easily skewed, and is not recommended as a serious method of displaying results. I have included tables of collected data and refer to raw numbers when necessary, but they do not form the basis of my statistical analysis. Large-scale quantitative language studies usually employ two one of methods - percentages of a whole, or 'tokens' (counting the occurrence of a particular word every thousand or ten thousand words). Tokens are a simple and effective way of presenting numbers in an easy-to-read fashion, but are only truly accurate of trends and patterns when utilised against a vast linguistic corpus which has been electronically processed. The corpus from which my data was drawn, although extensive, is too small for such an analysis. Ultimately, using percentages is the ideal mode of interpretation for my raw data, creating trends and patterns visible on a graph while still displaying the idiosyncrasies of an individual text, with trendlines used to illustrate general direction and rate of change. For most of my studied forms, only two variants have been recorded and graphed (the outlier being $<\mathrm{ea}><\mathrm{e}>$ and $<\mathrm{ee}>$ for $\mathrm{ME} / \varepsilon: /$ ), and in some cases, when there is a steady and statistically unremarkable shift (such as hem to them), or the development is almost entirely uniform (such as mo to more), the variants of Pynson and de Worde 
have been graphed and discussed together in the interests of space. The huge variety in change, standardisation, and variation of conservative and innovative forms means that no one system of statistical analysis can be applied that will suit each change perfectly; what I have attempted to do is use a simple interpretative method which can be applied to as many forms as possible, with minor deviation where it is necessary and appropriate.

The nature of historical linguistics, the parameters of my study, and the resources available (particularly the imposed time limit of a Master's thesis) necessitated a methodology which was neither a traditional macro-level corpus study conducted electronically, nor a micro-level detailed examination of most or all extant works of an individual writer. Instead, I attempted to strike a delicate balance between both methods, using a combination of judgement and random sampling at regular intervals over a period of time in order to compile a manual corpus of texts which was both reasonably representative of the entire printing careers of Pynson and de Worde, and yet small enough to examine in close detail. In all, ten language forms have been selected for study, a combination of phonological, morphological, and orthographic, with the intent to clarify the confusion around the nature of spelling variation, language change, and standardisation between these two particular printing houses. 
Table 1.1. Morphology Raw Data

\section{Richard Pynson}

\begin{tabular}{|c|c|c|c|c|c|c|c|c|}
\hline them & hem & them & $\%$ & $\%$ & hem & them & $\%$ & $\%$ \\
\hline 1490 & 8 & 68 & 10.5 & 89.5 & 35 & 27 & 56.5 & 43.5 \\
\hline 1495 & $\mathrm{O}$ & 32 & $\mathrm{O}$ & 100 & 0 & 57 & $\mathrm{O}$ & 100 \\
\hline 1500 & $\mathrm{O}$ & 16 & $\mathrm{O}$ & 100 & 2 & 40 & 4.8 & 95.2 \\
\hline 1505 & $\mathrm{O}$ & 36 & $\mathrm{O}$ & 100 & $\mathrm{O}$ & 55 & $\mathrm{O}$ & 100 \\
\hline 1510 & $\mathrm{O}$ & 21 & 0 & 100 & $\mathrm{O}$ & 38 & $\mathrm{O}$ & 100 \\
\hline 1515 & $\mathrm{O}$ & 59 & $\mathrm{O}$ & 100 & $\mathrm{O}$ & 39 & $\mathrm{O}$ & 100 \\
\hline 1520 & $\mathrm{O}$ & 42 & 0 & 100 & $\mathrm{O}$ & 28 & O & 100 \\
\hline 1525 & $\mathrm{O}$ & 51 & $\mathrm{O}$ & 100 & $\mathrm{O}$ & 52 & $\mathrm{O}$ & 100 \\
\hline 1530 & 0 & 48 & $\mathrm{O}$ & 100 & $\mathrm{O}$ & 34 & 0 & 100 \\
\hline nor & ne & nor & $\%$ & $\%$ & ne & nor & $\%$ & $\%$ \\
\hline 1490 & 35 & 4 & 89.7 & 10.3 & 25 & 6 & 80.6 & 19.4 \\
\hline 1495 & 17 & $\mathrm{O}$ & 100 & 0 & 21 & 0 & 100 & 0 \\
\hline 1500 & 5 & 3 & 62.5 & 37.5 & 16 & 4 & 80 & 20 \\
\hline 1505 & 8 & 28 & 22.2 & 77.8 & 4 & 7 & 36.4 & 63.6 \\
\hline 1510 & $\mathrm{O}$ & 6 & $\mathrm{O}$ & 100 & 2 & 7 & 22.2 & 77.8 \\
\hline 1515 & 6 & 22 & 21.4 & 78.6 & 4 & $\mathrm{O}$ & 100 & 0 \\
\hline 1520 & 2 & 22 & 8.3 & 91.7 & $\mathrm{O}$ & 9 & $\mathrm{O}$ & 100 \\
\hline 1525 & 5 & 20 & 20 & 80 & 7 & 11 & 38.9 & 61.1 \\
\hline 1530 & 1 & 32 & 3 & 97 & 13 & 6 & 68.4 & 31.6 \\
\hline those & tho & those & $\%$ & $\%$ & tho & those & $\%$ & $\%$ \\
\hline 1490 & 7 & $\mathrm{O}$ & 100 & $\mathrm{O}$ & 8 & 2 & 80 & 20 \\
\hline 1495 & $\mathrm{O}$ & 6 & $\mathrm{O}$ & 100 & 5 & $\mathrm{O}$ & 100 & $\mathrm{O}$ \\
\hline 1500 & $\mathrm{O}$ & 1 & 0 & 100 & 2 & 0 & 100 & $\mathrm{O}$ \\
\hline 1505 & $\mathrm{O}$ & 1 & 0 & 100 & 1 & $\mathrm{O}$ & 100 & $\mathrm{O}$ \\
\hline 1510 & $\mathrm{O}$ & 0 & 0 & 0 & 3 & 1 & 75 & 25 \\
\hline 1515 & $\mathrm{O}$ & $\mathrm{O}$ & $\mathrm{O}$ & $\mathrm{O}$ & 1 & $\mathrm{O}$ & 100 & $\mathrm{O}$ \\
\hline 1520 & $\mathrm{O}$ & $\mathrm{O}$ & $\mathrm{O}$ & O & O & 5 & $\mathrm{O}$ & 100 \\
\hline 1525 & $\mathrm{O}$ & $\mathrm{O}$ & $\mathrm{O}$ & $\mathrm{O}$ & 1 & 14 & 6.7 & 93.3 \\
\hline 1530 & 0 & 13 & 0 & 100 & $\mathrm{O}$ & 9 & 0 & 100 \\
\hline from & fro & from & $\%$ & $\%$ & fro & from & $\%$ & $\%$ \\
\hline 1490 & 6 & 15 & 28.6 & 71.4 & 14 & 12 & 53.8 & 46.2 \\
\hline 1495 & 19 & 15 & 55.9 & 44.1 & 11 & 11 & 50 & 50 \\
\hline 1500 & 6 & 6 & 50 & 50 & 9 & 9 & 50 & 50 \\
\hline 1505 & 10 & 13 & $43 \cdot 5$ & 56.5 & 3 & 21 & 12.5 & 87.5 \\
\hline 1510 & 1 & 23 & 4.2 & 95.8 & $\mathrm{O}$ & 26 & $\mathrm{O}$ & 100 \\
\hline 1515 & 3 & 15 & 16.7 & 83.3 & 14 & 11 & 56 & 44 \\
\hline 1520 & 3 & 19 & 13.6 & 86.4 & 4 & 28 & 12.5 & 87.5 \\
\hline 1525 & $\mathrm{O}$ & 11 & $\mathrm{O}$ & 100 & 3 & 28 & 9.7 & 90.3 \\
\hline 1530 & 3 & 31 & 8.8 & 91.2 & 7 & 6 & 53.8 & 46.2 \\
\hline more & mo & more & $\%$ & $\%$ & mo & more & $\%$ & $\%$ \\
\hline 1490 & 0 & 17 & 0 & 100 & 2 & 25 & 7.4 & 92.6 \\
\hline 1495 & $\mathrm{O}$ & 16 & 0 & 100 & 1 & 21 & 4.5 & 95.5 \\
\hline 1500 & 2 & 17 & 10.5 & 89.5 & $\mathrm{O}$ & 37 & $\mathrm{O}$ & 100 \\
\hline 1505 & $\mathrm{O}$ & 21 & $\mathrm{O}$ & 100 & $\mathrm{O}$ & 16 & $\mathrm{O}$ & 100 \\
\hline 1510 & $\mathrm{O}$ & 11 & $\mathrm{O}$ & 100 & 0 & 21 & 0 & 100 \\
\hline 1515 & $\mathrm{O}$ & 10 & 0 & 100 & $\mathrm{O}$ & 8 & 0 & 100 \\
\hline 1520 & $\mathrm{O}$ & 8 & 0 & 100 & 1 & 12 & 7.7 & 92.3 \\
\hline 1525 & $\mathrm{O}$ & 20 & $\mathrm{O}$ & 100 & $\mathrm{O}$ & 45 & $\mathrm{O}$ & 100 \\
\hline 1530 & 2 & 11 & 15.4 & 84.6 & 2 & 7 & 22.2 & 77.8 \\
\hline
\end{tabular}


Table 1.2. Raw Data pt. 1

\section{Richard Pynson}

\section{Wynkyn de Worde}

\begin{tabular}{|c|c|c|c|c|c|c|c|c|}
\hline eModE /ð/ & $\langle\mathbf{d}\rangle$ & $<$ th $>$ & $\%$ & $\%$ & $<\mathbf{d}>$ & $<$ th $>$ & $\%$ & $\%$ \\
\hline 1490 & 31 & 3 & 91.2 & 8.8 & 43 & 4 & 91.5 & 8.5 \\
\hline 1495 & 29 & 7 & 80.6 & 19.4 & 23 & 10 & 69.7 & 30.3 \\
\hline 1500 & 11 & 2 & 84.6 & 15.4 & 34 & 4 & 89.5 & 10.5 \\
\hline 1505 & 4 & 7 & 36.4 & 63.6 & 21 & 5 & 80.8 & 19.2 \\
\hline 1510 & 4 & 3 & 57.1 & 42.9 & 24 & 1 & 96 & 4 \\
\hline 1515 & 7 & 3 & 70 & 30 & 24 & 5 & 82.8 & 17.2 \\
\hline 1520 & 4 & 21 & 16 & 84 & 10 & 11 & 47.6 & 52.4 \\
\hline 1525 & 5 & 4 & 55.6 & 44.4 & 2 & 12 & 14.3 & 85.7 \\
\hline 1530 & 10 & 7 & 58.8 & 41.2 & 8 & 33 & 19.5 & 80.5 \\
\hline eModE /g/ & $<\mathbf{y}>$ & $<$ g $>$ & $\%$ & $\%$ & $<\mathbf{y}>$ & $<$ g $>$ & $\%$ & $\%$ \\
\hline 1490 & 17 & 18 & 48.6 & 51.4 & 25 & 12 & 67.6 & 32.4 \\
\hline 1495 & 6 & 12 & 33.3 & 66.7 & 20 & 19 & 51.3 & 48.7 \\
\hline 1500 & 1 & 29 & $3 \cdot 3$ & 96.7 & 6 & 32 & 15.8 & 84.2 \\
\hline 1505 & o & 20 & 0 & 100 & 23 & 24 & 48.9 & 51.1 \\
\hline 1510 & 17 & 5 & $77 \cdot 3$ & 22.7 & 6 & 37 & 14.0 & 86 \\
\hline 1515 & 2 & 18 & 10 & 90 & 3 & 27 & 10 & 90 \\
\hline 1520 & 2 & 37 & 5.1 & 94.9 & O & 45 & O & 100 \\
\hline 1525 & 0 & 46 & 0 & 100 & 0 & 24 & 0 & 100 \\
\hline 1530 & 0 & 44 & 0 & 100 & 0 & 32 & 0 & 100 \\
\hline $\mathbf{M E} / \mathbf{a} /$ & $<\mathbf{0}\rangle$ & $<\mathbf{a}>$ & $\%$ & $\%$ & $<\mathbf{0}>$ & $<\mathbf{a}>$ & $\%$ & $\%$ \\
\hline 1490 & 31 & 15 & 67.4 & 32.6 & 37 & O & 100 & O \\
\hline 1495 & 31 & 24 & 56.4 & 43.6 & 38 & 1 & 97.4 & 2.6 \\
\hline 1500 & 8 & 17 & 32 & 68 & 45 & 3 & 93.8 & 6.3 \\
\hline 1505 & 4 & 24 & 14.3 & 85.7 & 18 & 16 & 52.9 & 47.1 \\
\hline 1510 & 28 & 5 & 84.8 & 15.2 & 23 & 18 & 56.1 & 43.9 \\
\hline 1515 & 17 & 95 & 15.2 & 84.8 & 16 & 29 & 35.6 & 64.4 \\
\hline 1520 & 0 & 54 & 0 & 100 & 2 & 19 & 9.5 & 90.5 \\
\hline 1525 & 0 & 26 & 0 & 100 & 20 & 13 & 60.6 & 39.4 \\
\hline 1530 & O & 43 & 0 & 100 & 3 & 30 & 9.1 & 90.9 \\
\hline
\end{tabular}


Table 1.3. Orthography Raw Data pt. 2

Richard Pynson

Wynkyn de Worde

\begin{tabular}{|c|c|c|c|c|c|c|c|c|c|c|c|c|}
\hline ME / $\varepsilon: /$ & $<$ ea $>$ & $\langle\mathbf{e}>$ & $<$ ee $>$ & $\%$ & $\%$ & $\%$ & $<\mathbf{e a}>$ & $<\mathbf{e}>$ & $<$ ee $>$ & $\%$ & $\%$ & $\%$ \\
\hline 1490 & 8 & 64 & 9 & 9.9 & 79.0 & 11.1 & 13 & 49 & 3 & 20 & 75.4 & 4.6 \\
\hline 1495 & 6 & 45 & 15 & 9.1 & 68.2 & 22.7 & 16 & 61 & 4 & 19.8 & $75 \cdot 3$ & 4.9 \\
\hline 1500 & 10 & 25 & 3 & 26.3 & 65.8 & 7.9 & 23 & 78 & 0 & 22.8 & 77.2 & 0 \\
\hline 1505 & 29 & 31 & 2 & 46.8 & 50 & 3.2 & 34 & 36 & 5 & $45 \cdot 3$ & 48 & 6.7 \\
\hline 1510 & 23 & 36 & 18 & 29.9 & 46.8 & 23.4 & 18 & 36 & 1 & 32.7 & 65.5 & 1.8 \\
\hline 1515 & 46 & 80 & 9 & 34.1 & 59.3 & 6.7 & 21 & 29 & 10 & 35 & 48.3 & 16.7 \\
\hline 1520 & 40 & 24 & 21 & 47.1 & 28.2 & 24.7 & 9 & 44 & 2 & 16.4 & 80 & 3.6 \\
\hline 1525 & 49 & 24 & 12 & 57.6 & 28.2 & 14.1 & 25 & 20 & 6 & 49 & 39.2 & 11.8 \\
\hline 1530 & 42 & 49 & 1 & $45 \cdot 7$ & 53.3 & 1.1 & 31 & 32 & 18 & 38.3 & 39.5 & 22.2 \\
\hline
\end{tabular}

\begin{tabular}{|c|c|c|c|c|c|c|c|c|}
\hline ME origin & $<\mathbf{e a}>$ & $<\mathbf{e}>$ & $\%$ & $\%$ & $<\mathbf{e a}>$ & $<\mathbf{e}>$ & $\%$ & $\%$ \\
\hline 1490 & 6 & 13 & 31.6 & 68.4 & 13 & 7 & 65 & 35 \\
\hline 1495 & 6 & 18 & 25 & 75 & 16 & 17 & 48.5 & 51.5 \\
\hline 1500 & 9 & 10 & 47.4 & 52.6 & 23 & 26 & 46.9 & 53.1 \\
\hline 1505 & 22 & 2 & 91.7 & 8.3 & 33 & 9 & 78.6 & 21.4 \\
\hline 1510 & 22 & 10 & 68.8 & 31.3 & 18 & 4 & 81.8 & 18.2 \\
\hline 1515 & 42 & 7 & 85.7 & 14.3 & 21 & 6 & 77.8 & 22.2 \\
\hline 1520 & 30 & 10 & 75 & 25 & 9 & 5 & 64.3 & 35.7 \\
\hline 1525 & 44 & 3 & 93.6 & 6.4 & 24 & 2 & 92.3 & 7.7 \\
\hline 1530 & 35 & 12 & 74.5 & 25.5 & 31 & 4 & 88.6 & 11.4 \\
\hline OE origin & $<\mathbf{e a}>$ & $<\mathbf{e}>$ & $\%$ & $\%$ & $<\mathbf{e a}>$ & $<\mathbf{e}>$ & $\%$ & $\%$ \\
\hline 1490 & 2 & 51 & 3.8 & 96.2 & 0 & 42 & 0 & 100 \\
\hline 1495 & O & 37 & 0 & 100 & $\mathrm{O}$ & 44 & 0 & 100 \\
\hline 1500 & 1 & 15 & 6.3 & 93.8 & 0 & 52 & 0 & 100 \\
\hline 1505 & 7 & 29 & 19.4 & 80.6 & 1 & 27 & 3.6 & 96.4 \\
\hline 1510 & 1 & 26 & 3.7 & 96.3 & 0 & 32 & 0 & 100 \\
\hline 1515 & 4 & 73 & 5.2 & 94.8 & 0 & 23 & 0 & 100 \\
\hline 1520 & 10 & 14 & 41.7 & 58.3 & 0 & 39 & 0 & 100 \\
\hline 1525 & 5 & 21 & 19.2 & 80.8 & 1 & 18 & 5.3 & 94.7 \\
\hline 1530 & 9 & 34 & 20.9 & 79.1 & 1 & 28 & 3.4 & 96.6 \\
\hline ca. $1500 / \mathbf{u}: /$ & $<\mathbf{0}>$ & $<\mathbf{0 O}>$ & $\%$ & $\%$ & $<\mathbf{o}>$ & $<\mathbf{0 O}>$ & $\%$ & $\%$ \\
\hline 1490 & 65 & 26 & 71.4 & 28.6 & 17 & 39 & 30.4 & 69.6 \\
\hline 1495 & 41 & 13 & 75.8 & 24.2 & 69 & 20 & 77.5 & 22.5 \\
\hline 1500 & 49 & 14 & 77.8 & 22.2 & 24 & 47 & 33.8 & 66.2 \\
\hline 1505 & 29 & 40 & 42.1 & 57.9 & 36 & 46 & 43.9 & 56.1 \\
\hline 1510 & 30 & 34 & 46.9 & 53.1 & 22 & 32 & 40.7 & 59.3 \\
\hline 1515 & 11 & 24 & 31.4 & 68.6 & 45 & 28 & 61.6 & 38.4 \\
\hline 1520 & 35 & 46 & 43.2 & 56.8 & 20 & 14 & 58.8 & 41.2 \\
\hline 1525 & 38 & 24 & 61.3 & 38.7 & 20 & 57 & 25.9 & 74.1 \\
\hline 1530 & 52 & 35 & 59.8 & 40.2 & 28 & 44 & 38.0 & 61.1 \\
\hline ca. $1500 / \mathrm{o}$ / & $<\mathbf{O O}>$ & $<\mathbf{0}>$ & $\%$ & $\%$ & $\langle\mathbf{O O O}\rangle$ & $<\mathbf{0}>$ & $\%$ & $\%$ \\
\hline 1490 & 97 & 117 & $45 \cdot 3$ & 54.7 & 111 & 79 & 58.4 & 41.6 \\
\hline 1495 & 17 & 110 & 13.4 & 86.6 & 26 & 143 & 15.4 & 84.6 \\
\hline 1500 & 14 & 75 & 15.7 & 84.3 & 87 & 104 & 45.5 & 54.5 \\
\hline 1505 & 49 & 138 & 26.2 & 73.8 & 43 & 157 & 21.5 & 78.5 \\
\hline 1510 & 45 & 119 & 27.4 & 72.6 & 30 & 131 & 18.6 & 81.4 \\
\hline 1515 & 54 & 132 & 29 & 71 & 33 & 100 & 24.8 & 75.2 \\
\hline 1520 & 25 & 183 & 12 & 88 & 16 & 133 & 10.7 & 89.3 \\
\hline 1525 & 6 & 117 & 4.1 & 95.1 & 15 & 151 & 9 & 91 \\
\hline 1530 & 8 & 209 & 3.7 & 96.3 & 9 & 186 & 4.6 & 95.4 \\
\hline
\end{tabular}




\section{Morphological Changes}

Morphology is the study of meaningful word-segments within a larger lexical unit, serving as a "bridge" between the phonology and syntax (Lass, Cambridge Vol. 2 91). Unlike phonology, which is in its nature too difficult to represent accurately in a traditional alphabet, morphological variation and change can transfer relatively cleanly from an utterance to a written unit. The morphology of English has transformed definitively from a synthetic system, whereby meaning (such as tense person, number, possession, etc.) is derived from a number of inflectional categories contained within a single lexical item to a "minimal relic system", with very little inflection (Lass, History of English 51). The loss of these inflections occurred largely within the late $\mathrm{OE}$ and early ME periods, as the phonological distinction of inflectional endings and unstressed syllables collapsed and declined to an unstressed final [ə] by the eleventh century. As well as this, the distinction between accusative and dative was lost and replaced with a single object case. This $-e n$ ending declined to $-e$, which then also vanished. This process was nearing completion in the north during the thirteenth century, and had probably extended to the whole country by the beginning of the fifteenth century, but was (somewhat erratically) retained in poetry until at least 1500 (Horobin, Chaucer Tradition 99). By the midsixteenth century, the only classes of lexical items to still bear any resemblance to the $\mathrm{OE}$ case forms were a handful of pronouns and auxiliaries, most of which changed most significantly in the latter half of sixteenth century such as the introduction of subject you, third-person singular $-s$ endings, and third-person plural are (Nevalainen and RaumolinBrunberg, Historical Sociolinguistics 152).

Although the paradigm shift was largely complete by the time de Worde and Pynson were printing, there were nevertheless a noticeable number of forms which still clung to the conservative 'medieval' variants, and were in the process of change. I have selected five such forms, which have an apparent 'point of change' in the late fifteenth or early sixteenth century: the third-person plural objective them (vs. hem), the demonstrative those (vs. tho), the prepositions from (vs. fro) and more (vs. mo), and finally the negative particle nor (vs. ne). Several such changes (such as them and from) have been incorrectly classified or discussed as spelling shifts in the past (Aronoff; Blake, "Reynard"; Fisher, Chancery English), but they are regarded here as morphological with consideration paid to the linguistic processes which motivate and direct these changes. The history behind these five changes, all of which stretch back to OE, illustrate different developments towards the modern standard, with examples of inflectional collapse, analogical levelling, and borrowing. The varying origins and diffusion of such changes through the fourteenth, fifteenth, and early sixteenth centuries signify a series of complex developments at differing rates far more diverse than traditional scholarship on the history of ‘Standard English' claims. 


\section{Third Person Plural Objective Pronoun (hem to them)}

The third person plural objective pronoun is the result of a Scandinavian borrowing which influenced the entire third-person paradigm in the ME period, beginning when nominative pei (they) displaced $h \bar{\imath}$ in the north of England either in the late OE or early ME period. The transition began first in speech and spread to text in the twelfth century, first recorded in the Ormulum, a text noted for the author's faithful representation of his native north-eastern dialect. The Old Norse pe33 (they) consistently replaced native $h \bar{l}$, indicating the process was, in the north, complete (Quinn 17). From this first instance, the use of the Scandinavian th-pronoun slowly spread throughout England.

The $e L A L M E$ gives an interesting picture of the distribution of third person plural forms in the century 1350-1450. While the nominative they spread essentially throughout England by the Late Middle English period, the saturation of possessive their and objective them is much less comprehensive, and limited largely to the old Danelaw region of the north-east. (eLALME items 28, 29, 39, 40, 51, 52). Chaucerian texts usually contain the borrowed they alongside native hem, hir(e), and her(e) (Werner 388). The relatively sluggish speed at which their and them is incorporated into the new mixed pronoun paradigm in southern ME brings the theory of borrowing into some question. Nevertheless, Howe suggests that them and their mature over the course of several generations as the result of analogical levelling of hem and hir, to conform to the introduced they (159), citing a number of similar examples in Germanic pronouns, particularly the spread of $h$ - in third person pronouns in Old Frisian, Old English, and Middle Dutch, as precedence for this process (84).

Although initially slow to penetrate the English language, the objective them gains some ground in the fifteenth century. Davis writes that "the third person plural has they nominative and, early in the [fifteenth] century... hem objective, but forms with initial thgradually appear" ("Grammar and Spelling” 495). In his survey of Chancery English, Fisher states that while their and they have come to dominate the native $h$-forms in the Chancery documents, hem is still the preferred form (148 occurrences) in comparison to them/theym/etc. (120); "clearly hem was very much alive" (Chancery English 44). Caxton himself seemed to prefer them, with no recorded use of hem in Fisher's study ("Caxton" 175), and them is the favoured variant in Gómez-Soliño's analysis of 21 of Caxton's texts, with theym the second variant. (109-116). Blake notes in his study of Reynard the Fox there is a 'relative frequency' in the hem/them of Caxton's and Pynson's texts (Pynson's edition being published in 1500), and no examples of hem can be found in de Worde's fragment (71). Lass states "Them was finally stabilised in the first decade of the sixteenth century." (History of English 75) Charles Barber writes "in the third-person plural, the 
Scandinavian forms they, them, their, and theirs are the normal ones by 1500", but also that "in the course of the Early Modern period, hem becomes less frequent, and is rare in the seventeenth century, although it is recorded as late as 1660 (151). Horobin, in his study of Caxton, Pynson, and de Worde's editions of The Canterbury Tales, concludes that hem remains the major form for Caxton and de Worde, while Pynson has entirely replaced this form with them. Interestingly, William Thynne's edition of Chaucer's works retains the original hem spellings, suggesting the form was certainly at that point an identifiable archaism and deliberately retained by the editor as a nod to the Chaucerian style (Chaucer Tradition 85, 88). Although the variants theym and theim were found throughout the texts, they have been treated here as belonging to the them variant, as the change studied here is the change from initial $h$ - to th-. Evidence from more texts is required to conclude if de Worde's retention of hem is a preservation of Chaucer's forms, or a reluctance to modernise, and if Pynson's rejection of the hem continues throughout his career.

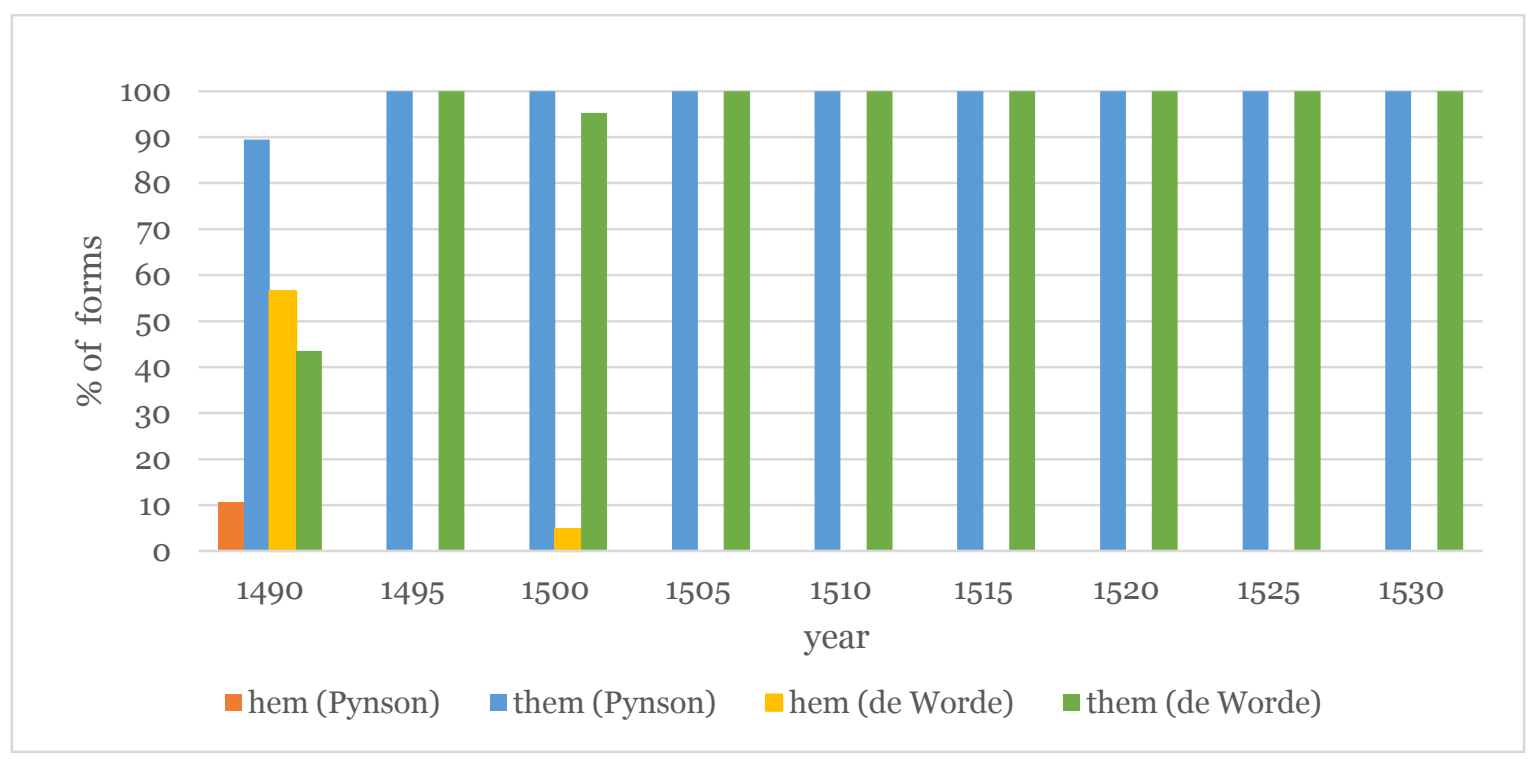

Fig. 1.1. Use of hem and them in Pynson and de Worde.

The results are largely typical of the trend towards them in the fifteenth century as seen in Caxton and the Chancery scribes. Hem exists only as a relict form in Pynson's earliest texts with just a few examples each, and by 1495, appears to have vanished completely. De Worde, however, is slightly less straightforward in the loss of hem. In the 1490 texts, hem is the dominant form, and although it has vanished by 1495 , returns twice in 1500 before disappearing entirely. Of the 35 examples of hem in 1490, 33 come from Text $\mathrm{B}$, which only has one example of them. It is unsurprising that the Text $\mathrm{B}$, with an older source, still clings to the $h$ - form, while Text A, a contemporary translation, uses them (and its variants) almost exclusively. Although hem was occasionally found in the late fifteenth century, it is obviously considered archaic even in the first years of de Worde's and Pynson's careers, and by 1505, hem was considered a relic. 


\section{Third-Person Plural Demonstrative Pronoun (Tho and Those)}

The third-person plural demonstrative pronoun those has two possible origins from OE. The first is the nom./acc. plural of this and these, $\mathrm{OE} p \bar{a} s$, and the second is the nom./acc. plural of the, that and those, OE $p \bar{a}$. Pyles states $p \bar{a}$, reduced to tho at the end of the OE period, became the norm in ME, and ultimately "gave way" to thos, from $p \bar{a} s$ (158). Ekwell says that those (from $p \bar{a} s$ ) was already in early ME, associated with tho, and displaced the earlier form (97). Lass, however, argues for a different strand of development, stating that while those resembles a relic of OE $p \bar{a} s$, it "is more likely an analogical development of the plural article $p a<O E p \bar{a}$, with added noun plural $-s$. The same development occurs a good deal later, with the southern stem vowel, which makes the Old English origin much less likely" (Cambridge Vol. 2 114). The inherent instinct to add the plural $-s$ to nouns, even sometimes at the expense of grammatical correctness, is somewhat frequent throughout English (as found in Greek loan-words such as synonym and stadium and numerous lexical items in Te Reo Maori until very recently,), but the former assumption appears to be preferred in traditional scholarship.

Whatever the morphological origins of the form, those came to be used more and more in the fifteenth century. Tho is the preferred form in the Chancery Standard, with 16 examples (including thoo and boo), compared to just two of those. (Fisher, Chancery English 390). Ekwall writes that tho is displaced in eModE (97), and Chaucer "only has that/tho(o), but Caxton has those as well... this form is then a fifteenth-century development" (114). Pyles agrees: "the form with $-s$ did not become common in the Midlands and the South until the late fifteenth century" (158). These four scholars all come to roughly the same conclusion, and it is reasonable to assume that those would therefore be, if not the sole variant, a reasonably established form in print during the period Pynson and de Worde operated their presses. While de Worde's texts still had enough data to draw some reasonable conclusions, the lack of data for Pynson (of the nine years in which data was collected, four had no results at all, and two just a single example) makes a graph visually unreliable and therefore one is not included - however those years that do contain evidence will still be considered in the overall analysis. 


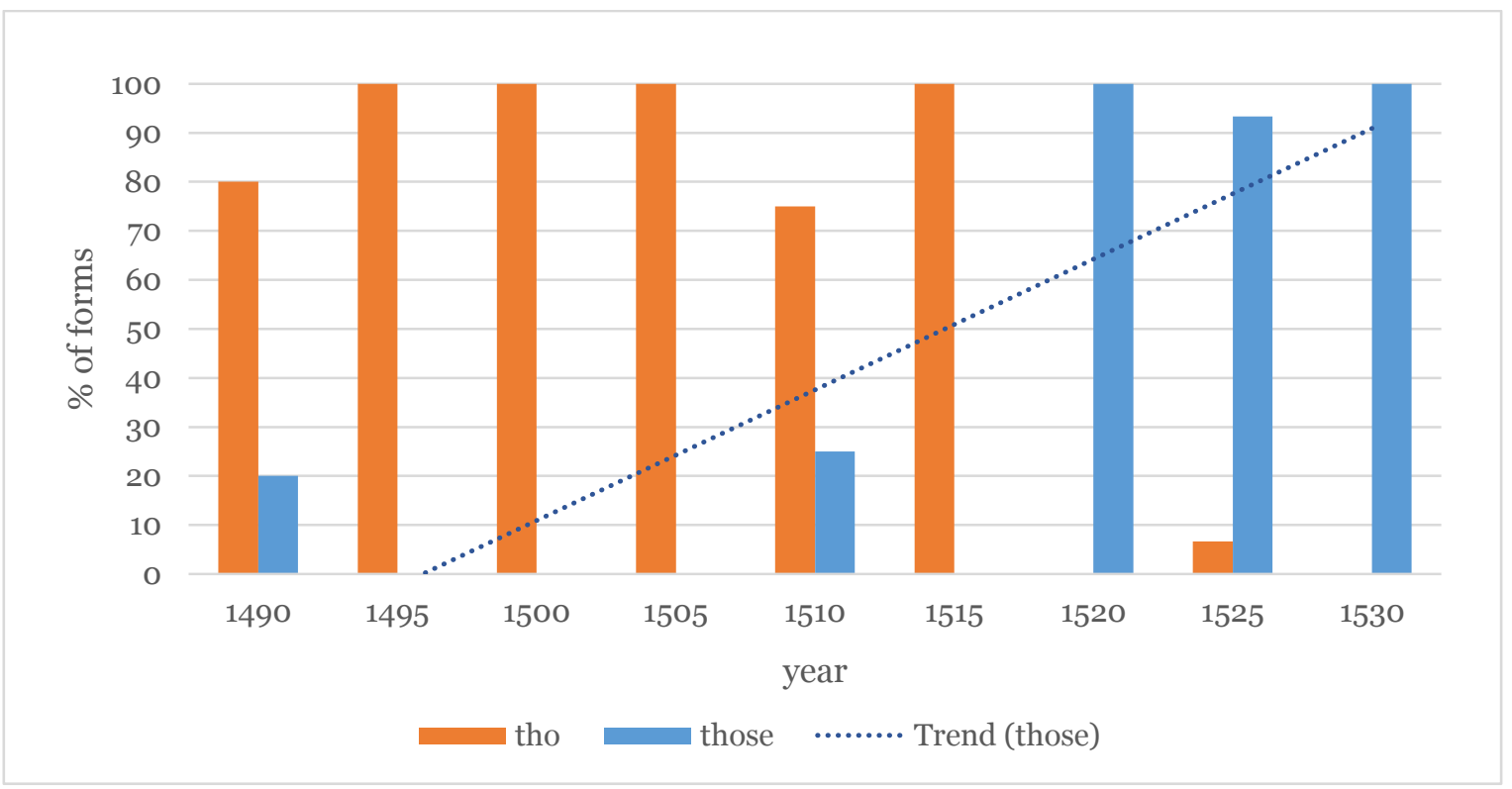

Fig. 1.2. Use of tho and those in Wynkyn de Worde.

Despite the scarcity of data available, particularly from Pynson's texts, we are nevertheless able to make some steady observations regarding the development of those over the course of forty years. In the 1490's tho is, for the most part, the dominant (and in some cases exclusive) form. The only significant exception to this is Pynson's 1495 Text A, containing 6 examples of those and none of tho, indicating that already for some the modern variant was established enough to make it into print. Pynson's data between 1500 and 1525 is negligible, but the occurrence of 13 examples of those and none of tho in 1530 makes it clear the innovative those has become the preferred usage. The use of tho in de Worde's house is relatively stable until 1515 , at which point it declines sharply. In de Worde's 1515 Text B, a reprint of the 1495 Text A, tho is retained, but in the 1530 reprint, has changed to those, indicating the earlier variant is an archaism.

\section{Fro and From}

The development to from, although it receives comparatively little attention as a reasonably straightforward and identifiable change, contains two major variants which are distinguished quite clearly as ME and eModE variants. Although fro exists in PresE as part of the expression to and fro, it is obsolete as a functional lexical item, a process which was apparently complete sometime in eModE. From has roots in OE, while fro is a development from Old Norse frá (OED "fro", $a d v$., conj.), existing initially as fra in the Scandinavian-influenced Ormulum. Frá (and also to a lesser extent fram) remain minor, distinctly northern and Scots variants, and the $<0>$ forms account for almost all forms in central and southern England. Although fro is the minor variant in the thirteenth and 
early fourteenth centuries, it comes to dominate from and became the majority form in late ME (eLALME item 28; MED "fro", prep.). This tendency continued in the fifteenth century; there are 72 examples of fro in Chancery English, compared to 30 of from (Fisher Chancery English 340), and Blake notes that Caxton and Pynson tend heavily towards the northern fro, while de Worde has a 'marked preference' for from in his textual fragment (“Reynard” 71).

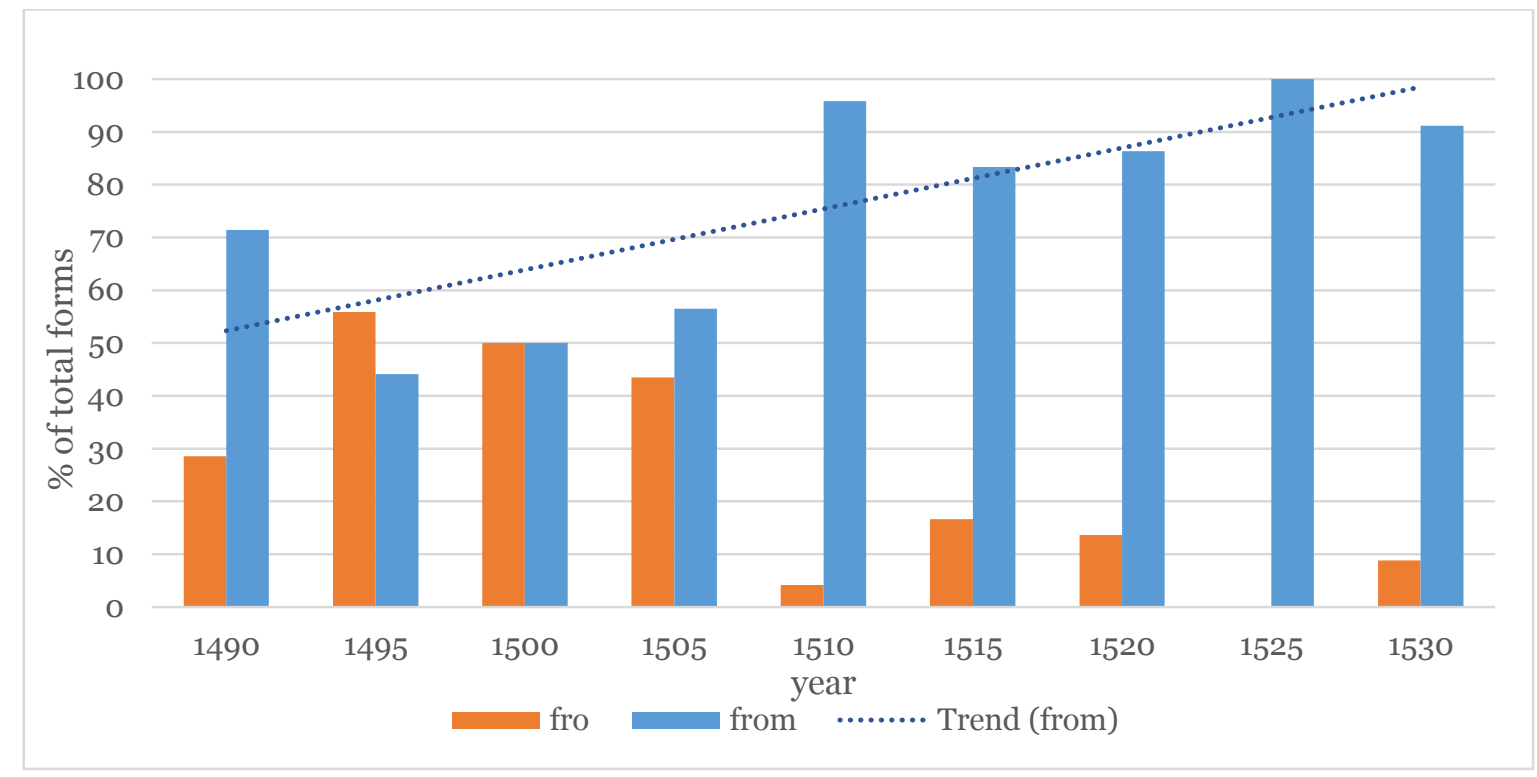

Fig. 1.3. Use of fro and from in Richard Pynson.

Although there is a small shift in popularity of the modern from in 1495 (typical of most texts printed before 1500), the overall decline of fro is relatively stable. The largest shift, between 1505 and 1510, marks the ultimate end of fro as a viable form. By 1530, just 3 examples are found within the sample texts, all in the Text B. Although fro is still identifiable as a variant of from it has within Pynson's texts declined to the point where, although not lost completely, is certainly very minor. 


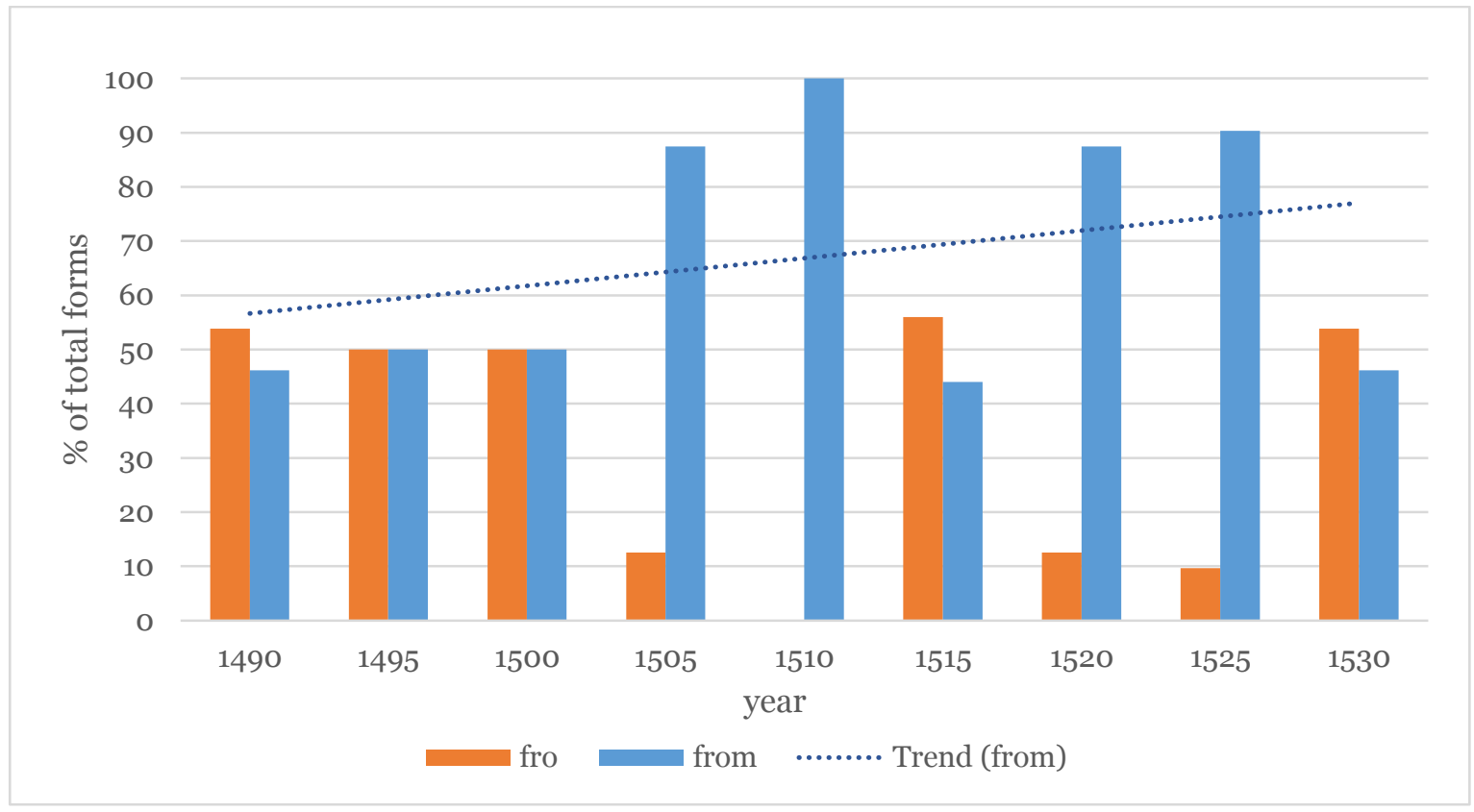

Fig. 1.4. Use of fro and from in Wynkyn de Worde.

The pattern of distribution in the texts of de Worde, however, is far more complex. Both forms are used evenly between 1490 and 1500, and the ten years beyond this suggest that fro is now regarded as a relict form. In 1515 however, fro makes a surprising comeback, accounting for 14 of 25 examples. This inconsistency cannot be localised to one text, as both the Text A and B contain numerous instances of fro, and no other forms studied experience quite a drastic shift as the fro/from development. The 1515 Text B is a reprint of the 1495 Text A, the Myracles of Oure Lady (albeit with minor emendations), and it would be expected that it was reproduced with as faithfully close to the original as possible; the Text A, however, is a new composition, written relatively early in the author's life (see appendix). The 1515 data is not the only major outlier in this otherwise thorough decline of fro; the same irregularity is also found in 1530 . This, however, can be attributed to one text in particular, the Text $\mathrm{B}$, a reprint of the 1515 Text $\mathrm{B}$. There are no examples of fro in the Text A, and there is, as would be expected, considerable closeness in various features of morphology and orthography between the three printings of the Myracles text, indicating a relatively faithful and accurate transfer from one edition to another. Considering the nature of these irregularities, the only notion that can be drawn with any certainty is that fro, while perhaps no longer prevalent, was still suitable enough to be included in its original form, rather than undergoing modernisation to from, as was the case with the other morphological forms hem and tho. 


\section{Mo and More}

The decline of $m o$ and rise of more in Late ME and eModE is an interesting collapse of a system that operated independently of external language contact. These lexical items are both found in early $\mathrm{OE}$ texts as ma, mara, and mae. Both forms are Germanic, entered the English language at a very early period, and are found alongside one another in OE texts, although ma appears to be the more common variant (DOE "ma", "mara"). There is no functional or practical difference between the two, and it is most likely that differentiation between the two terms was determined by stress and metre. $M a$ and mara lowered to mo and more in the late OE period, and the earlier [a] forms remained as minor northern variants (OED 'more', adj., pron.,, and prep.; 'mo', adv.1, pron.', and $a d j$.$) . Both forms coexisted throughout the ME period, and were found$ alongside one another in manuscripts (for example, MS Bodl. 959). As inflectional endings and unstressed final syllables declined in $\mathrm{ME}$, the final $-e$ in more ceased to be pronounced. The word often appeared at the end of the sentence, and it quite likely that the specifications of poetry, such as rhyme, stress and metre continued to necessitate the two separate forms. In the fifteenth century, prose became the favoured mode of writing, and as both the phonological and functional difference between the two variants collapsed, $m o$ very quickly became a minor form. Just 6 forms are noted in Chancery, compared to 94 of more (Fisher, Chancery English 360). As the pattern of variation was close between the two printers, I have graphed them together for the short discussion.

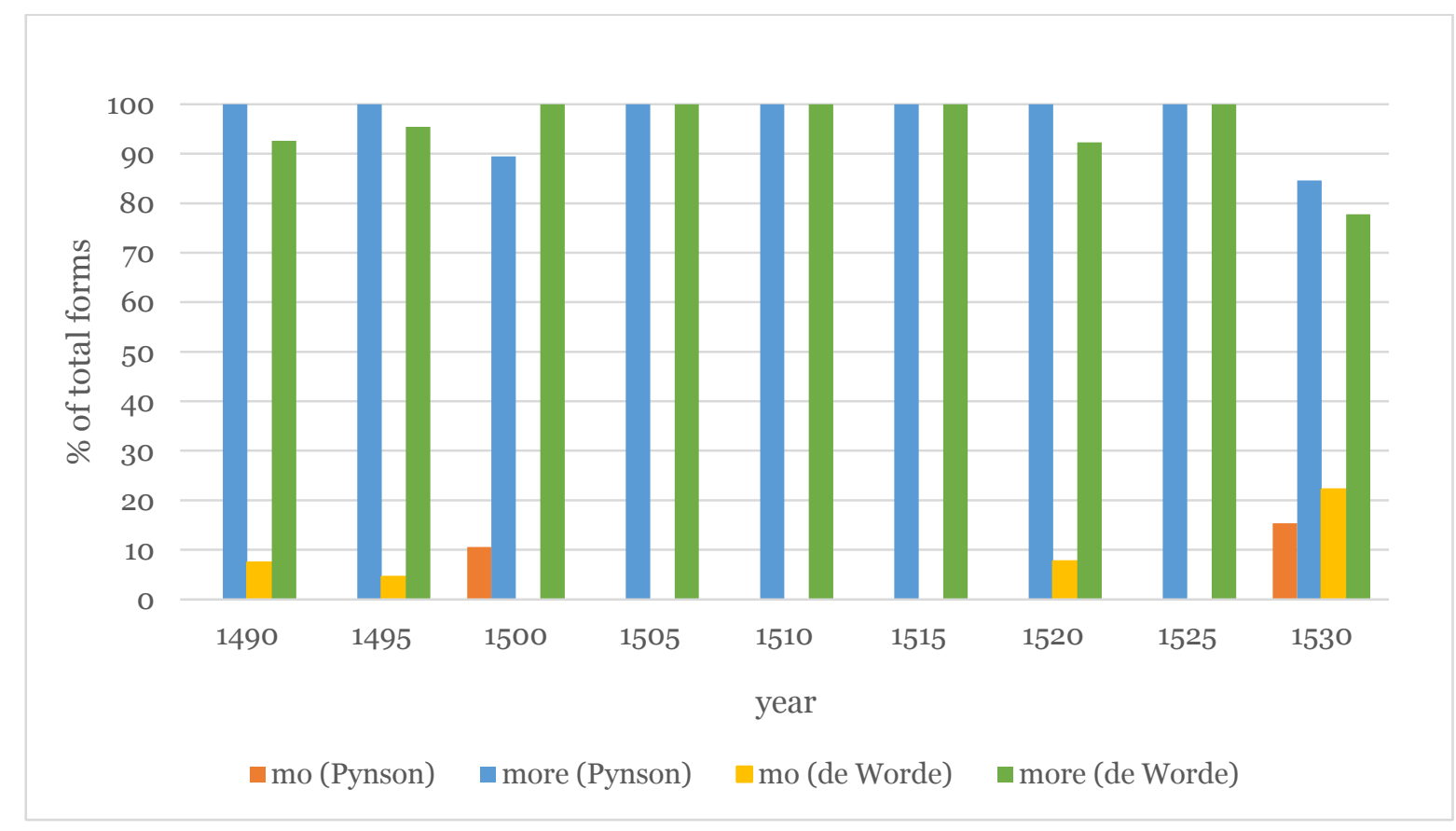

Fig. 1.5. Use of mo and more in Pynson and de Worde. 
It is immediately clear from this graph that mo has become a very minor form, disappearing entirely between 1505 and 1525, save for a single example in de Worde's 1520 Text B. There are just 10 examples of mo throughout the entire range of data, compared to 333 of more. What is interesting is the apparently sudden resurgence of mo in 1530. Both printers have just two examples apiece, but with only 7 examples of more for de Worde, and 11 for Pynson (compared to 1525, when the printers had 45 and 20 examples respectively), mo ends up appearing as a more significant variant than it actually is. Although the forms have perhaps not decisively vanished by 1530, the otherwise very low occurrence of $m o$, existing usually as single examples within a text, indicates that the form is archaic, and more is undoubtedly the preferred form of these printers.

\section{Negation (ne and nor)}

Negation in English is a complex morphosyntactic development spanning all three major periods of the language, and to discuss it as a whole in the context of Pynson and de Worde with the detail required to make qualified assumptions would necessitate a study far beyond the boundaries imposed in this particular analysis. For this reason, the morphological shift of supported ne to nor, a change in negation pinpointed most closely to the turn of the sixteenth century, is the particular development studied here, with consideration paid to the structural changes in negation which influenced the shift from one form to another.

Due to the complexity of OE syntax, tracing definitive rules and patterns of negation in early English is particularly difficult (Mazzon 48). The development of supported ne began in this period - ne and nought (OE nawiht, noght, etc.) were frequent negators, and instances of multiple negation featuring both lexical objects increased as nought came to be used as a reinforcer after the verb (Fischer and van der Wuff, 157). Multiple negation, particularly through the use of the simple marker ne, became commonplace in ME, if not necessarily the 'rule' as asserted by most scholars (Mazzon 55). By the end of the fourteenth century, however, accumulation of negators seem to have become the exception rather than the rule, at least in prose (62). The unsupported adverbial ne - with no other negators within a clause - declines in late ME, notably in prose (Iyeri 22), functioning mainly as an intensifier alongside other negators. Throughout the fifteenth century, ne gradually disappears in almost all positions and functions (Barber 199; Tieken-Boon van Ostade 207; Ujaki 274).

About the same time as ne was rapidly declining (and the issue of which shift instigated the other is not fully resolved), not (reduced from earlier OE nought) emerged as a marker of negation, rendering ne semantically empty (Fischer and van der Wuff 157). As not took over, multiple negation began to wane. Only one lexical item was necessary to 
convey negation, and this phenomenon was mostly lost in the sixteenth century, with Shakespeare the last major writer to use the expression, although it remains in many varieties of non-standard speech (Barber 199; Nevalainen and Tieken-Boon van Ostade 295). Initially not was found in its old position alongside the now-deleted ne, but preceding the loss of multiple negation, not rose (Fischer 85). The result was a new syntactic structure, particularly aux + not + verb, at the cost of the older verb + not (Fischer and van der Wuff 157).

As not replaced the adverbial function of ne in late $\mathrm{ME}$, the conjunction ne is the last form to linger in extant English texts. This was ousted in the early sixteenth century by nor (Mazzon 71), either a shortening of neither (OED “nor, conj.") or a combination of ne + or (MED “nor, conj.”). The earliest attested example dates to 1375 , with examples increasing throughout the fifteenth century (MED "nor, conj."). Ne is the slim favourite in Chancery, with 77 forms, compared to 43 of nor (and 21 of the variant ner), indicating that it is not 'lost' quite as early as a number of academic texts assume (Fisher, Chancery English 362-3). There are no studies of Caxton's works from which to draw an example. Based on the conclusions drawn by various scholars and analysis of extant fifteenthcentury evidence, it is clear that the shift between the conjunctions ne and nor occurs between the late fifteenth and early sixteenth centuries.

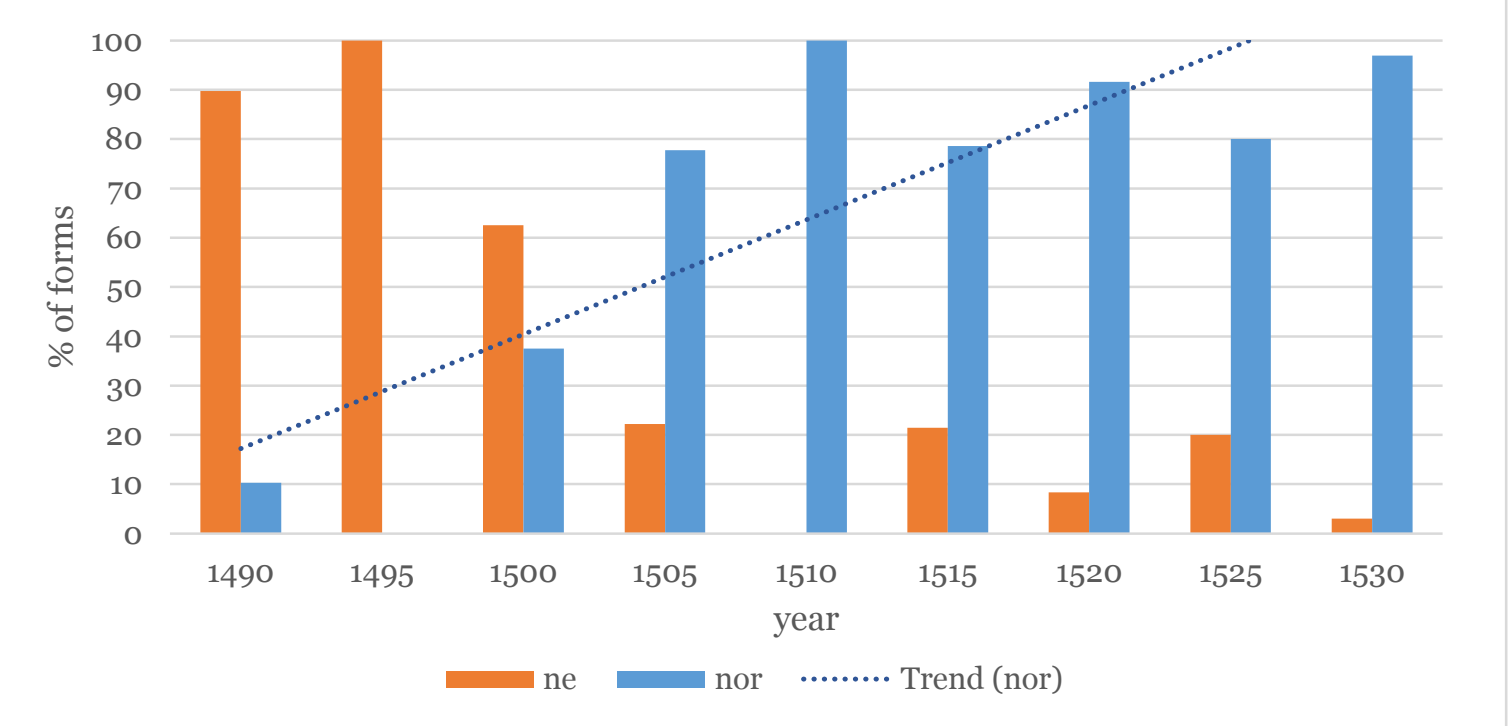

Fig. 1.6. Use of ne and nor in Richard Pynson.

Pynson's texts exhibit a clear trend towards the modern nor, with a sharp decline in the older ne forms after 1500 to almost nil, continued steadily throughout the studied period. By 1530, there is only a single recorded example of ne in the Text $\mathrm{B}$ ("sithe ye neuer hiderto coude ne dyd answere thervnto"), alongside 13 examples of nor, indicating 
the change, in a practical sense, is essentially complete. Of the 12 sample texts from 1505 onwards, only 7 contain any examples of ne, none of which have it as the majority variant.

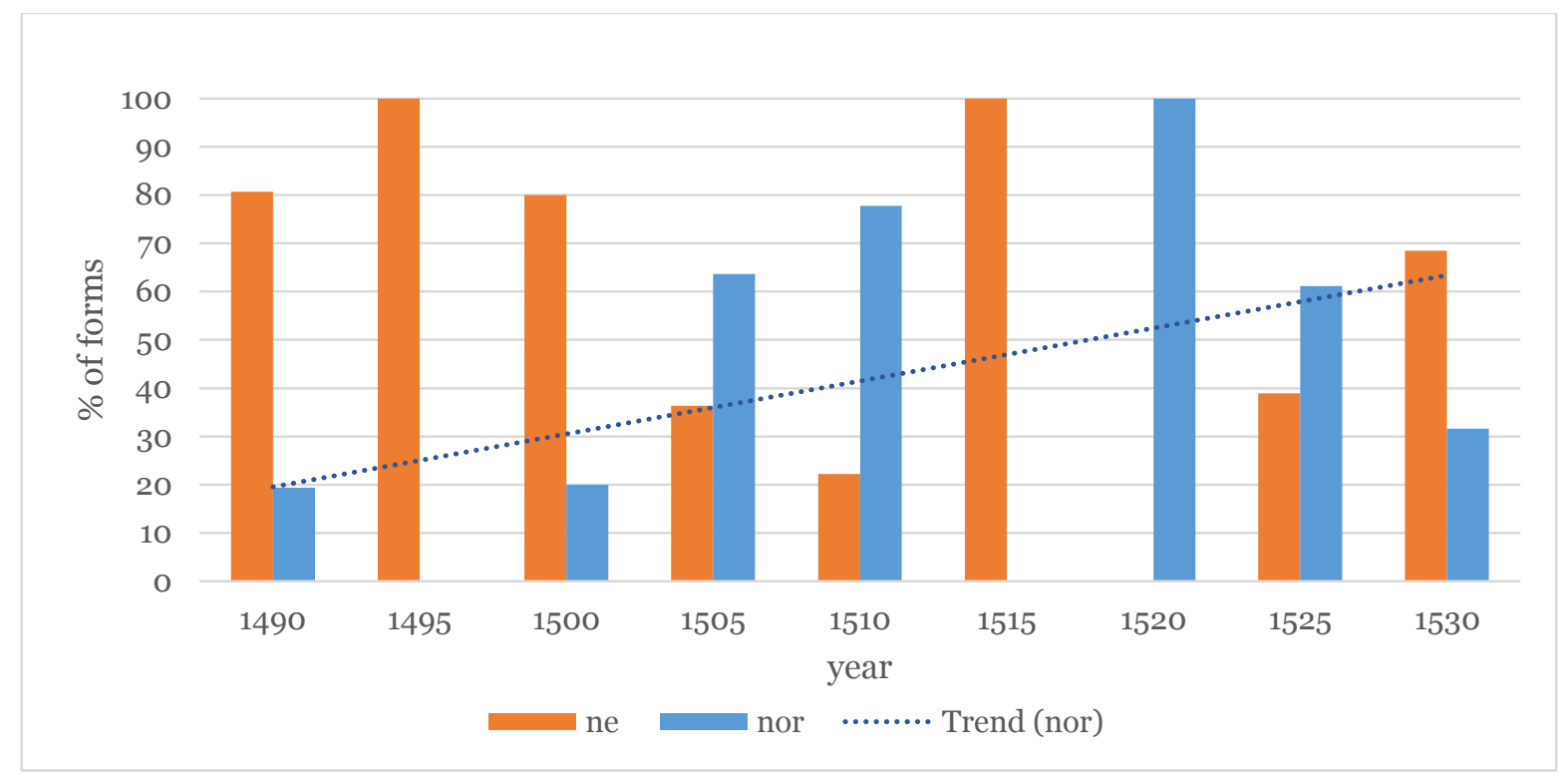

Fig. 1.7. Use of ne and nor in Wynkyn de Worde.

On the other hand, the data for Wynkyn de Worde's texts present quite a muddled story. Until 1510, a similar pattern is seen with de Worde as with Pynson, with a decline of $n e$ in between 1495 and 1510. However, this decline is not matched with a rise of nor as seen in Pynson's evidence, and the results of 1515 and 1520 give the impression that the form was in significant disorder. In truth, these two years suffer (as has been seen in other studies in this thesis) from a lack of data. In 1515, there are just 4 examples of $n e$ across both sample texts and in 1520, 9 of nor. Aside from this 1515 irregularity, after 1500 it is only in 1530 (with 11 of 13 examples coming from the moralising instructional guide to householders, which naturally contains a large number of negatives and has a rather stiff and old-fashioned style) where ne overtakes nor.

The shift from ne to nor cannot be cleanly quantified in such a way without a number of other considerations. This particular morphological shift is more complex than the previous studied, such as tho to those and hem to them. The grammatical function of $n e$, and decline of multiple negation must also be addressed. Firstly, although the adverb $n e$ declined in late ME, it has not entirely vanished from the printed texts of Pynson and de Worde. Three examples of an unsupported ne survive - Pynson's 1490 and 1495 Text A, and de Worde's 1505 Text A - functioning as a simple negator with no supporting negatives in the surrounding clause. Nor is never used in the studied examples as an adverb or unsupported negator in the same way as ne, and these three early examples of a declining usage, while perhaps not statistically significant, are nevertheless an important point to consider when evaluating language variation and change in this context. 
The second factor to consider is multiple negation. Once a commonplace feature, multiple negation declined in the fifteenth and sixteenth centuries and by the early seventeenth century, was considered outdated. I found a number of examples of multiple negation within the sample texts - 33 convincing instances in total, spanning from 1490 right through to 1530. 17 examples occur between 1490 and 1500, and only 2 are found after 1520. Multiple negation and ne are both clearly declining, and when it does remain, tends to be in texts which are either prints or reprints of older material, or in an intentionally didactic and archaic style. A similar pattern is noted by Nishimura; lengthy and repetitive instructive texts showed a notable tendency to retain multiple negation, while concise works, particularly legal texts, consciously avoided multiple negation as early as the fifteenth century $(87,90)$. The decline of multiple negation and loss of adverbial ne put both Pynson and de Worde well on trend with a number of current assumptions about negation in the late fifteenth and early sixteenth century.

\section{Conclusion to Morphology}

Despite differences in function, diffusion, and development, these five particular items all express a relatively steady and uniform trend towards the modern variant. For the forms, them, from and more, change was already well underway by 1490 , and what we see is a continuation of an established trend, rather than linguistic innovation. The remaining those and nor, however, were relatively minor in the early years of printing, increasing over time, and by 1530 were established and (with the exception of nor in several of de Worde's later texts) even majority variants, with the previous ne and tho in decline.

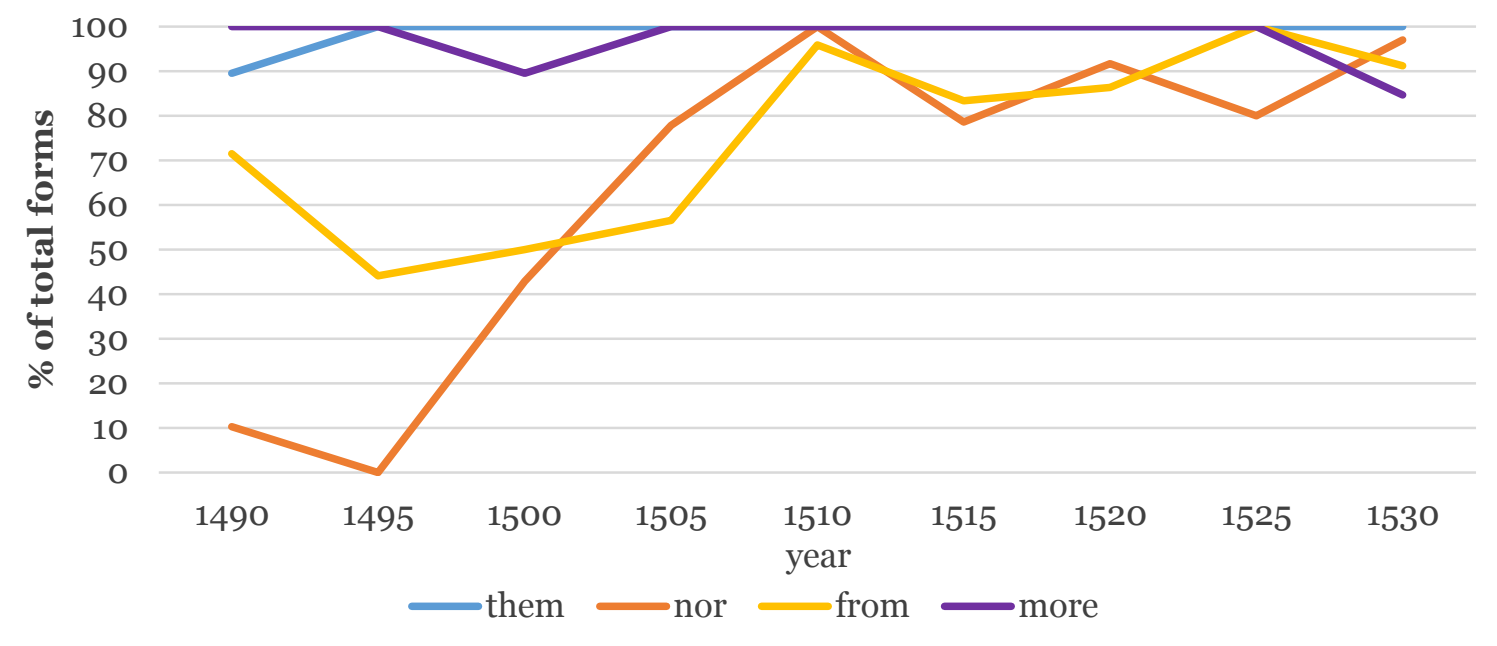

Fig. 1.8. Overall modernisation of morphological forms in Richard Pynson. 
What is remarkable is how closely the forms often correspond to one another, establishing a noticeable pattern of overall modern usage which increases over time. Pynson's texts, in particular, express a definitive and conclusive growth of modern variants. Progression was essentially complete by 1510 , and despite a slight decrease in 1515 there is no real evidence of destabilisation. By 1530, 80\% of all instances across the five morphological forms (including those, which, while not graphed due to incomplete data, had a convincing 13 examples compared to zero of tho in the final year) were modern variants. By 1530, Richard Pynson's morphology (as analysed within this study) is undoubtedly modern.

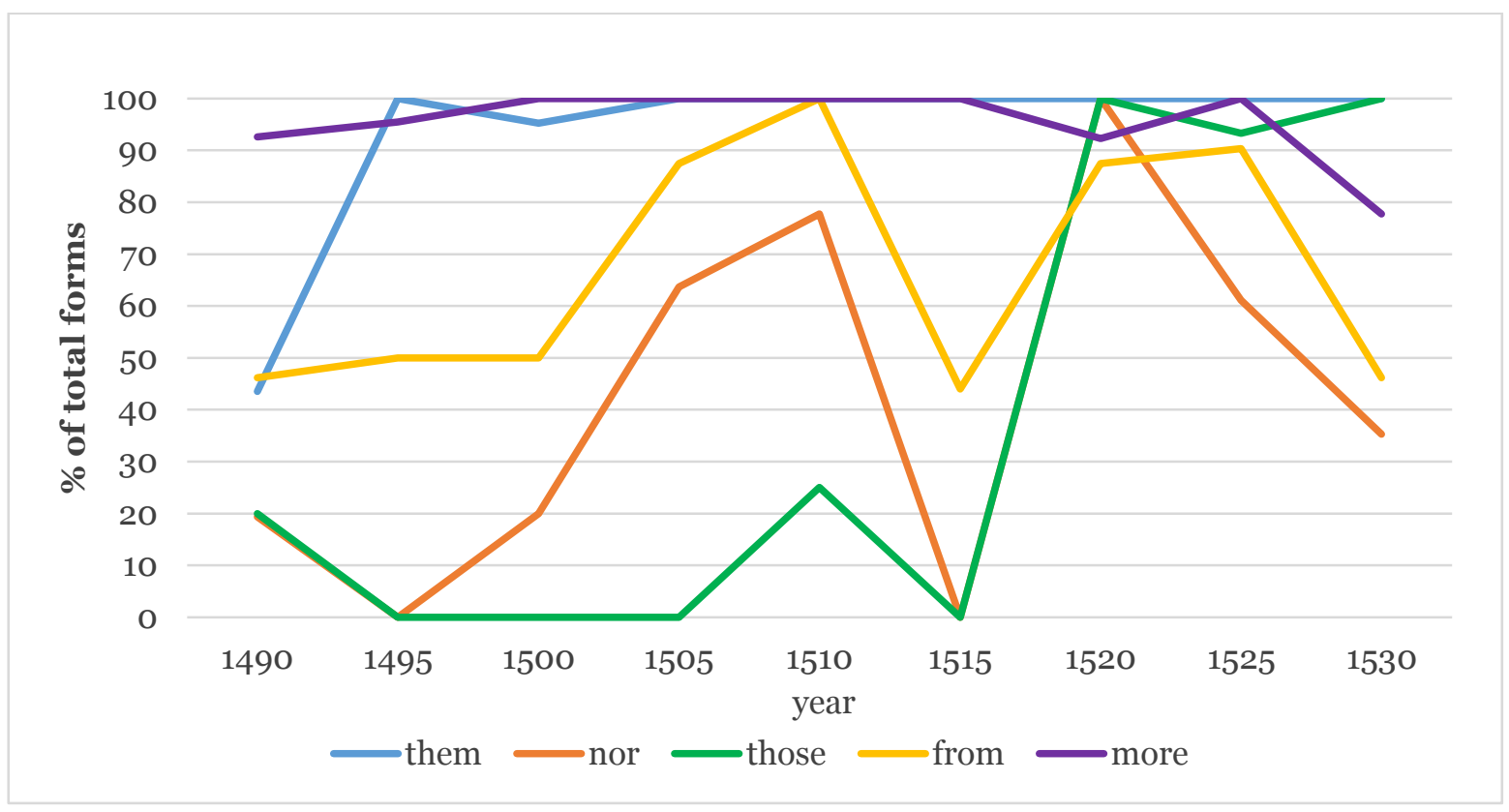

Fig. 1.9. Overall modernisation of morphological forms in Wynkyn de Worde.

The picture for Wynkyn de Worde, however, is far murkier. The growth in general proceeds slowly, and initially the innovative variants are less popular than in Pynson. Despite being slow to start, these variants reach a satisfying (if not as conclusive) majority by 1510, reflecting Pynson's results, with those the only outlier to an otherwise steady development. This trend, however, is disrupted twice. From, nor, and those decline significantly in 1515 , with two forms dropping to zero, and this decline is repeated in 1530 , although it is considerably less dramatic. As stated above, the most likely reason for this is the material, as the same text appears in both years studied and appears to preserve certain morphological forms which even by 1510 are considered conservative, if not yet totally archaic. Morphological spelling in de Worde's house is less innovative than that of Pynson's, with a slower and less consistent progression towards development, but this does not imply that de Worde was a conservative printer. Modern variants were often employed, and it is the impression of the text, rather than of the house itself, which influenced the speed and direction of morphological change. 


\section{Orthographic Change}

The relationship between written and spoken language can be a simple correspondence of elements ( $<$ bat $>$ for example, is pronounced [bæt]) or a complex distribution of larger segments of spoken and written discourse (consider as ache and moustache), often coexisting within a single lexical item (Liuzza 29). The connection between the changing phonological structure of ME and eModE, and the written representation of these sounds during this time remains a highly contentious and difficult issue, despite extensive scholarly interpretation from both a phonological and orthographic viewpoint. Typically, the initial occurrence of innovative spelling has been taken as an indication of a long period of spoken change which is slow to penetrate the textual medium. What became clear in my study was that it is extremely difficult to completely divorce phonology and orthography from each other and trace the development as two individual, exclusive processes. Any phonological evidence gleaned from a written source, save for careful phonetic transcriptions in IPA and the most detailed illustrations of individual sounds, must be treated as impure representations constrained within a second, often phonetically artificial, system. To study the development of orthography while turning a blind eye to the phonological processes which influence it is equally restrictive. To study phonology in ME and eModE, careful attention must be paid to orthography, and vice versa.

The rapid modernisation of the English language in the fifteenth and sixteenth centuries has already been discussed at length, but there is another important linguistic development which warrants mention: the Great Vowel Shift, a process whereby the long vowels in English rose significantly between 1400 and 1700. The first shift happened in the fifteenth century, as /o:/ rose to /u:/ and /e:/ to /i:/, instigating a chain reaction which dramatically affected the phonetic inventory of the English speech community (Barber 104; Lass, The Shape of English 133). The potential influence of the GVS on the spelling of the vowels in question is discussed within the individual sections.

The physical reality of print medium naturally has a significant influence on the orthography of de Worde and Pynson. Early printed books closely resemble contemporary manuscripts to the casual reader (Hirsh XV 1); Caxton, for example, had over 270 pieces of type in imitation of medieval handwritten script (Cusack 37). Although the first printers had this large stock of varying type, they were nearly always sourced from Europe, and as a result the non-standard graphs $3, b$, and $\partial$ were lost. Deformed examples of vestigial $p$ are seen in some eModE abbreviations, such as $y^{e}$ for the and $y^{t}$ for that, but such instances decline during the sixteenth century (although it has resurfaced in the anachronistic prefix Ye Olde), and the resulting English alphabet is entirely Roman (Upward and Davidson 24). This disparity between print and manuscript manifests itself 
in early printed texts, as printers working from medieval manuscripts are forced to revise these textual features in accordance with the new medium.

In order to explore the relationship between phonological and orthographic forms, I selected changes that (at least in the past) had a phonetic difference, rather than purely orthographic graphemes which represent typically 'Middle' or 'Modern' characteristics (such as $\langle\mathrm{i}\rangle \mid\langle\mathrm{y}\rangle$ or $\langle\mathrm{u}\rangle \mid\langle\mathrm{v}\rangle$ ), particularly as such interchanges were not resolved until the close of the sixteenth century or later (Upward and Davidson, 185, 190). The final six forms (intervocalic $<\mathrm{d}>$ and $<\mathrm{th}>$ representing PresE medial $/ \mathrm{d} /,<\mathrm{y}>$ and $<\mathrm{g}>$ representing PresE /g/ in give/again, $<\mathrm{a}>$ and $<\mathrm{o}>$ representing nasal $\mathrm{ME} / \mathrm{a} /,<$ ea $>$ and $<$ e $>$ representing closed monosyllabic $\mathrm{ME} / \varepsilon$ :/, <0> and <oo > representing ca. 1500 / $\mathrm{o}$ / and $/ \mathrm{u}: /$ ) represent a fine assortment of vowels and consonants, with incipient and recognised modern variants alongside distinct medieval forms which are established, or in the final stages of decline. Because of the transitional nature of the period studied, it is necessary to define whether these phonemes are in their ME, PresE or intermediate (e.g. ca. 1500, which is neither ME or eModE). These five spelling forms embody a wide scope of change, with phonetic shifts such as consonantal lenition and vowel shifting, alongside examples of language contact, such as Scandinavian and French borrowings.

\section{PresE Medial /ð/ (moder, hyder to mother, hither)}

The gradual development from medial - $d$ - to -th-is a linguistic shift that blurs the line between regular sound change, analogy, and orthography. While a number of scholars have noted a general change during the fifteenth and sixteenth centuries, there is no satisfactory explanation for the irregular and at times confusing progression of this specific language form. Extensive studies have been conducted on the nature of phonetic change and the concept of a phoneme, both as a psychological construct and a literal reality. Phonetic segments (such as the [d] or [th] sound) are "subject to hierarchical dependencies as well as linear sequencing and the segments themselves can be either simple or complex" (Lodge 19). One core problem in defining representations of these sounds is the huge amount of phonetic variation found in all languages (Hooper 111). In her 2007 study of the dental fricative - the variant studied in this short analysis conducted in Ohio USA, Bridget Smith found participants recognised this phoneme anywhere from a plosive to an approximant, indicating that even in a (supposed) period of standardisation, variation of the individual speaker is still widespread (22). It is expected that some level of variation would be found in any language form of Middle English, and the intervocalic $<\mathrm{d}>$ and $<$ th $>$ spellings are no exception. 
What makes the attempt to clarify the nature of this shift from the $<\mathrm{d}>$ to $<$ th $>$ form difficult is the complexity and underlying patterns of variation found in extant medieval texts. The $M E D$ and the $e L A L M E$ show that for most lexical items, a favoured or even exclusive form is established as early as the twelfth century; for example, $<\mathrm{d}>$ for moder, fader, thyder, whyder, weder, and hyder, and $<$ th $>$ for other, whether, rather and fether. Medial [d] and [ð] appear to be allophones of the same phoneme, with little or no functional difference between the pair (the only notable example of complementary distribution, other and udder, had differing vowel sounds until the late sixteenth century). This variation is sometimes attributed to analogy, and it is suggested that it is also possible that early Scandinavian influence, with its medial fricatives, compounded [this variation], which persisted well into Middle English" (Smith 26). On the other hand, the $O E D$ states "the modern English -ther... in father and mother is often wrongly said to be due to the analogy of brother, or to Scandinavian influence; it is really the result of a phonetic law common to the great majority of English dialects (OED "father, n."). The 'phonetic law' in discussion here is lenition, or weakening of the medial consonant, a common linguistic process, but the persistent variation of this phoneme in $\mathrm{OE}$ and $\mathrm{ME}$ is not characteristic of typical consonantal weakening. Old High German, for example, experienced a sound shift in the other direction as the interdental fricative hardened to a plosive. "It was first written $d$ in the eighth century in Bavarian and part of the Alemannic. In the ninth century it is written $d$ throughout Alemannic and East Franconian. In the tenth century it is written $d$ in Rhine Franconian, but in Middle Franconian it is not written $d$ until the eleventh century. The orthographic change, which reflects the sound change of voiceless interdental fricative to voiced alveolar stop, spread from the south-east to the north-west" (Russ 49).

In order to better investigate the complexity of the variation between the medial $d$ - and -th-forms, I have selected the word mother for a more in-depth analysis. With 83 variant forms (OED "mother, n." "), mother is a relatively common noun and is a good base for such a study. The $M E D$ records 309 examples of moder (and variant spellings); of this significant collection, only seven are rendered $<\mathrm{th}>($ or $<\mathrm{p}>$ ), and all instances occur from the 1470's and onwards (MED "modor, n."). A similar pattern is found in the eLALME, where, of 374 examples, only nine use $<\mathrm{th}>$ or $<\mathrm{p}>$, and as in the $M E D$, all these examples are dated from the late fifteenth century and beyond (Brown, 121; Furnivall and Harmelius, $x v$; Hanna 50; Hodgson xi; Page 80-83; Patterson 443; Reames 264). The earliest instances of mother are interestingly found in personal correspondence, such as the John Paston II's letter to his mother in 1469 (Davis, “Two Brothers" 27), and Thomas Montagu's (1452-1517) letter to his parents written from Oxford, presumably in the late 1460's or early 1470's (eLALME, LP 769). 
This seems to support the OED's assertion that mother simply underwent a standard phonetic sound change, probably in the fifteenth century, as the alveolar stop softened to a fricative. It is attractive to assume that mother and father, as long, stressed vowels (in comparison to gather, whither, and together, for example) were comparatively stable. However, an interesting exception to this trend throws such conclusions into uncertainty - the northern town of Motherby, Cumbria. Motherby is mentioned in various documents nine times between 1252 and 1370. Of these nine examples, six are rendered with the <th>, the earliest record dated to 1279 (Armstrong 198; Kristensson 87; Sedgefield 81). This variation between the $<\mathrm{d}>$ and $<\mathrm{th}>$ indicates there is little functional difference in the spelling of mother on a purely phonetic basis, such as the vowel quality therefore the exclusive preference for $<\mathrm{d}>$ in mother until the late fifteenth century must have had some sort of analogical or semantic meaning. Although the exact nature of this particular process may never be fully realised, it can be stated with some assurance that mother had, at least in spelling, a stable $<\mathrm{d}>$ variant that persisted well into the fifteenth century.

Turning to discussion of the ME to EModE development, there is some consensus regarding the shift from the $<\mathrm{d}>$ to $<\mathrm{th}>$ spelling, sometimes linked to a change in pronunciation. Davis writes that the form "in the course of the fifteenth century changed the plosive $d$ to a voiced fricative th", and the spelling of this change in pronunciation is irregular, with Skelton, for example, rhyming fethers with edders (Grammar and Spelling" 502). Dobson dates the change in pronunciation to "about 1400", and notes the midsixteenth century orthoepists have shifted their instructive spellings almost entirely to $<$ th $>$ (956). Scragg positions the point of change in the "sixteenth century" (32). Fisher reports the "usual alternation between $d$ and th in words like whether and thither, an ambiguity not resolved until the $16^{\text {th }}$ century or later" and "to what extent these spellings reflect pronunciation remains a question" (Chancery 30). Blake mentions the variation between medial $<\mathrm{d}>$ and $<\mathrm{th}>$ in his study of Reynard, but draws no conclusion from his brief notes (70). These reports perpetuate the common view that while there was a sound change in Late ME, exactly when it occurred and to what extent the shift in spelling reflects the shift in pronunciation, remains unclear.

A short explanation of the lexical units selected for analysis and the phonemic distinction is necessary. For a number of items, particularly other, rather, neither, and either, the $<$ th $>$ became stable long before the period of analysis. The units selected are those which exhibited variation between $<\mathrm{d}>$ and $<\mathrm{th}\rangle$, as it is the variation and development of this language form which this analysis is focused most strongly on. The medial consonant in murder and burden is not studied; as a sound change occurring in the opposite direction it would require a graph of its own, and there was not enough 
evidence with which to draw any definitive conclusions. The phoneme here has been designated as /ð/, as it is the accepted pronunciation around the time of printing, according to scholarly evaluation. As the voiceless $/ \theta /$ is very minor in the intervocalic position, the distinction has not been retained.

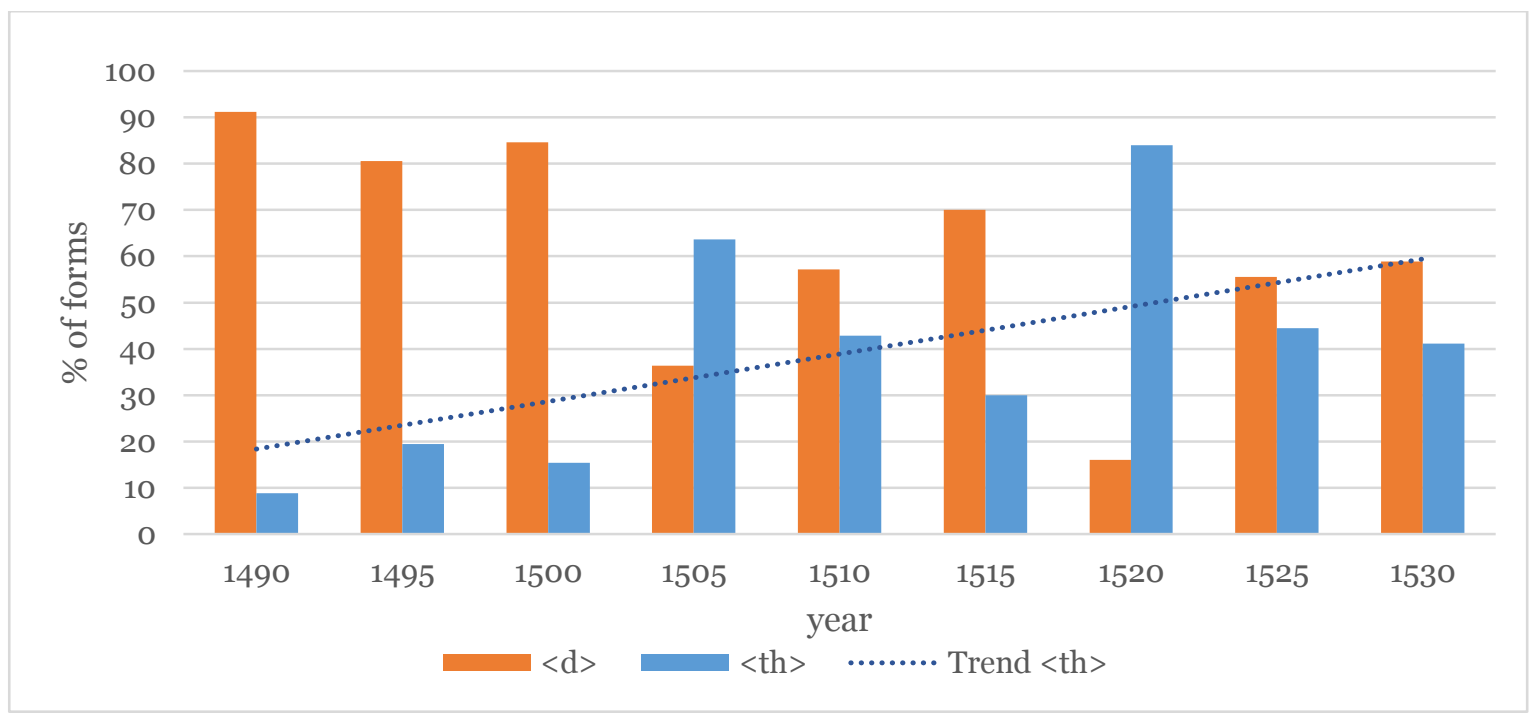

Fig. 2.1. Spelling of intervocalic /ð/ in Richard Pynson

The data gathered from Richard Pynson's sample texts yields initially unimpressive results - the dominant variant in 1530 is still $<\mathrm{d}\rangle$, despite a significant spike in $<$ th $>$ spellings in 1520. The inconsistency of $<$ th $>$ variants, particularly between 1505 and 1520 , suggest the spellings are irregular, and there is no definitive trend towards modernisation throughout Pynson's career, and an attempt to find any pattern in this variation requires further analysis.

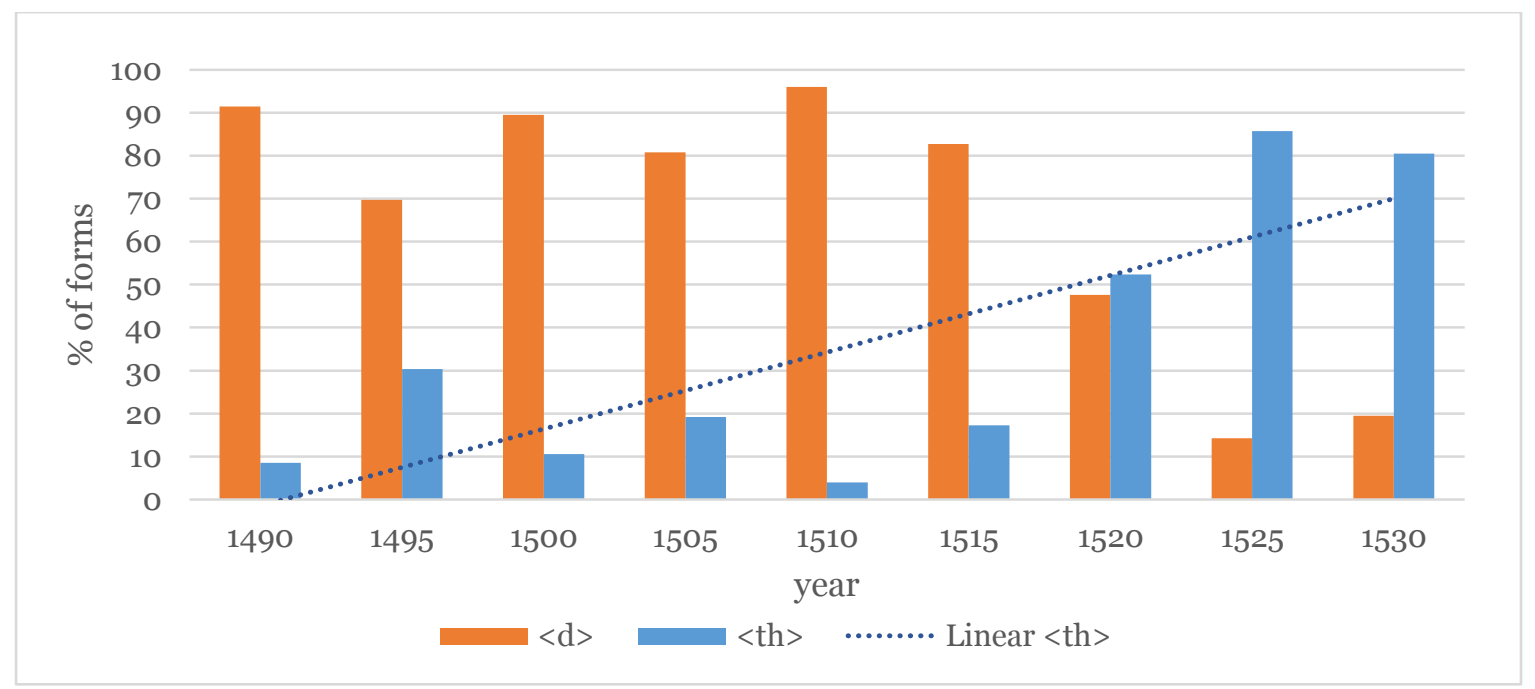

Fig. 2.2. Spelling of intervocalic /ð/ in Wynkyn de Worde. 
The decline of the $<\mathrm{d}>$ and rise of $<\mathrm{th}>$ in the works of Wynkyn de Worde, however, is immediately obvious. De Worde's texts exhibit a generally steadier decline of $<\mathrm{d}>$, with the sharpest drop in 1515-1525, from 24 examples of $<\mathrm{d}>$ to just 2 . The sudden increase of $<$ th $>$ forms between 1525 and 1530 is quite unusual and is a cause for interest. The results of both printers indicate that the variation between $<\mathrm{d}>$ and $<\mathrm{th}>$ is, as it is in the ME period, motivated to a certain extent by analogy. Combined, there were 66 examples of medial $<\mathrm{d}>$ in the 1490 texts of both printers, compared to just 14 of $<$ th $>$, and $18<\mathrm{d}>$ and $40<\mathrm{th}>$ occurrences in 1530 . The shift can be grouped into three classes of lexical units; the nouns, (mother, father, and brother), the adverbs (hither, thither, whither, whether), and finally, the two lexical items gathered and together. These three groups tend to shift in similar patterns, suggesting the possibility of analogical influence, and what follows is a discussion of forms. Although the occurrences of each group of forms are generally too small to graph, it is still possible to infer trends and developments from the examples found.

Firstly, the nouns exhibit a very interesting change in form during the period studied. De Worde's 1520 Text B, composed in the same year of its printing, is the first to introduce the modern spellings, with 8 examples. The 1525 Text B uses forefaders and broder alongside father, and afterwards there are no instances of either moder, fader, or broder in any samples of de Worde's texts. Pynson's shift is more significant; There is only one example of $<\mathrm{d}>$ in 1520 , alongside 12 of $<\mathrm{th}>$, and none are found in the 1525 and 1530 samples; if it still lingered on in his later texts outside the scope of this sampling, it would most likely have been very rare. This mutual shift is incredibly fast, from 20 examples of $<\mathrm{d}>$ and 2 of $<$ th $>$ (both the often inconsistent brother) in 1515 , to just $2<\mathrm{d}>$ examples and $23<$ th $>$ examples in 1520. As well as this, feather, which is spelled with $<\mathrm{d}>$ in Pynson 1495 Text A and de Worde 1505 Text B, is <th $>$ in 1520, suggesting a development in line with the other nouns which contain the variant medial consonant. It is extremely difficult to attribute such a dramatic, universal shift wholly to natural, regular sound change, considering the continued irregularity of the adverbs, and gather/together. This shift encompasses both the texts of contemporary writers and the printings of old manuscript material, suggesting an effort to modernise this group of units with very few exceptions. Evidently, $<\mathrm{d}>$, the clear dominant variant found in writing just fifty years ago, was considered so outdated in this group of nouns as to be a relic of the past century. The variant in this context was lost, possibly as early as 1525, signifying the development of a stable standard which is, at least in the works of Pynson and de Worde, almost complete.

The shift in the adverb group, while perhaps less comprehensive, nevertheless signifies a considerable change to the newer variant. Of the medial $<\mathrm{d}>$ and $<$ th $>$ words 
which have not yet settled into their current variant by early ME, it is this group which experiences the most variation within individual lexical units (eLALME items 173, 265, 285, 286). Although there are dominant variants for most words, there is nothing like the preference for one particular variant, as is found in the nouns, or in the gather/together group. This confusion is also seen in the texts of Pynson and de Worde, with variation between $<\mathrm{d}>$ and $<$ th $>$ from the outset, and a strong tendency towards $<\mathrm{d}>$. What follows is a noticeable trend towards the modern in whether, hither, and thither; in de Worde's texts, the $9<\mathrm{d}>$ spellings of this group of words drops to zero, and one $<$ th $>$ (whether) increases to 6 in the years 1510 to 1525 . Although a slight increase of $<\mathrm{d}>$ occurs in 1530 , it is still lower than any other point of the period studied. Pynson has fewer examples of these adverbs, but the data collected is nevertheless promising. Only one example of $<\mathrm{d}>$ is found after 1515, whyder (whither) in 1530 Text A, and whether is spelled exclusively with <th> from 1505, with examples gathered in 1510, 1515, and 1520. There is an identifiable trend towards the modern variant, but scattered examples of adverbs with $<\mathrm{d}>$ alongside modern variants in the final decade of analysis indicate that the shift is far from comprehensive, as it is observed in the noun group.

Finally, gather and together are collated as they share a pattern of development considerably slower than the nouns and adverbs. Although they do not share the same grammatical function, there is a certain semantic connection between the two lexical units, and the phrase 'gather together' occurs across several texts studied (in de Worde's 1490 Text B, Pynson's 1490 Text B, and his 1530 Text A) which could explain the similarity in development from $<\mathrm{d}>$ to $<\mathrm{th}>$. Unlike the nouns and adverbs, which trace a generally steady path towards development between 1490 and 1530, gather and together have 4 examples of $<\mathrm{d}>$ and just one of $<$ th $>$ in de Worde's 1530 examples. Similarly, Pynson has $8<\mathrm{d}>$ examples and no $<\mathrm{th}>$ in 1530. The only text which bucks this trend is Pynson's 1520 Text B, which has 3 examples of together and 2 of gather, alongside 3 of togyder, with none of gader. This indicates the beginnings of a shift towards the $<\mathrm{th}>$, but it is not fully realised before 1530 . The preference for $<d>$ in the overwhelming majority of the texts indicates that, at least in formal and semi-formal texts, the lexical iterms gather and together were developing at notably slower rate than the nouns and even adverbs, and the significant moments of change occur after the houses of Pynson and de Worde have been taken over.

Apart from this oddity, the texts for the most part reflect the closing stages of a language shift which has been developing since the ME period. There is some confusion surrounding the actual nature of the linguistic shift, and to what extent the spelling reflects actual pronunciation of the forms. Evidence from various scholars suggests that there was certainly some level of variation amongst pronunciation of certain forms, 
particularly the adverbial constructions, throughout the ME period. Such variation is evident in many speech communities today, particularly dialects such as Caribbean English, African-American Vernacular English, and Maori English, which frequently adopt the medial [d] form in speech. However, the relative stability of a number of lexical units from an early stage in the English language shows that at least in writing, the two forms were not interchangeable, and patterns of variation indicate a certain level of semantic or analogical influence by the writers of English. The spread of medial $<$ th $>$ in the mid-tolate fifteenth century, originally in personal documents rather than professional and official works, is in line with the arguments of Dobson and Davis, who position the beginning of this weakening (at least in the appropriate speech communities) in the early fifteenth century. The rapid adoption of this form in the texts of de Worde and Pynson, particularly the nouns, indicates the majority of the speech community probably used the [ð] in informal and semi-formal speech, and the modernisation of the older $<\mathrm{d}>$ spellings in the 1520's shows a deliberate effort to reflect this pronunciation. Based on the data collected, and on existing studies of fifteenth-century English, there is sufficient evidence to claim that the rise of the medial $<$ th $>$ in the lexical units which had not yet achieved stability occurs largely within the era of Wynkyn de Worde and Richard Pynson.

\section{PresE /g/ (yeue and ayen to giue and agayn)}

PresE / $\mathrm{g} /$ as it is found in words such as give is quite a curious development in that it is influenced not necessarily by any phonological or internal processes, but chiefly by language contact. Rendered in OE as an "open" $<3>$ essentially functioned as a grapheme for a number of different sounds, including the approximate [j] in positions with an adjacent front vowel (Quirk and Wrenn 16). This [g] was a borrowing from the Old Norse settlers who inhabited the north-east of England from the Anglo-Saxon period (Geipel 20). The introduction of the grapheme $<\mathrm{g}>$ came with the Norman Conquest, as the French sought to introduce their own Carolingian script. The new $<$ g $>$ was utilised alongside $<3>$ (and the occasional variant $<\mathrm{y}>$ ) to represent this recent distinction $[\mathrm{g}]$ and [j], and words such as give were spelled zeue or yaf, a system established as early the twelfth century (Scragg 22).

The first recorded instances of $<\mathrm{g}>$ in this context was in the Ormulum (Bjorkman 154) and throughout early ME grew in northern texts (Upward and Davidson 83). Usage of [g] and the <g> grapheme slowly increased throughout the medieval period, spreading from the north-east into the south and west of England. The eLALME illustrates this shift in maps detailing the distribution of $\langle\mathrm{g}\rangle$ and $\langle 3\rangle \mid\langle\mathrm{y}\rangle$; the study of ME against shows the $<\mathrm{g}>$ variant, while strongest in the north, is found quite frequently in the south, 
particularly in the east, with occurrences as far south-west as Devon, whereas the $\langle 3\rangle /\langle y\rangle$ variants, while heavy in the south, stop entirely at Lancashire and Yorkshire, apart from two lone exceptions in Cumbria (item 36). A similar pattern is repeated in the maps of give, where the $<\mathrm{g}>$ forms, while mostly northern, are still found in the south and southwest (including the most south-western data point in Cornwall), while the non-g variants are extremely rare in the northern counties, with just five examples noted (item 154). Although both variants still have their core geographical domains, the occurrence of $<\mathrm{g}>$ in southern and western areas of England indicate strongly that the Scandinavian variant is slowly displacing the original $\mathrm{OE}<3>$ (and the minor $\mathrm{ME}<\mathrm{y}>$ ) throughout England.

During the fifteenth century, this shift to $<$ g $>$ steadily increased. Use of the $\mathrm{OE}<3>$ slowly declined both as a representation of [j] and of the velar fricatives (which came to be written as $\langle\mathrm{gh}\rangle$ ) in late ME. Instead writers who still wanted to express the [j] came to adopt the more minor $<y>$ variant. This was particularly prolific in Chancery, where $<y>$ was the overwhelming majority in example yeuen (128 to 1) and ayenst (75 to 4). Again was the only lexical item featuring a majority $<\mathrm{g}>$ variant (22 to 8). There were few examples of $<3>$, which was declining in late ME in all contexts (Fisher, Chancery English 28) The preference for $<y>$ over $<3>$ is a result of the Chancery scribes seeking to replace the fading $<3>$ with their closest variant, as $<3>$ in the $e L A L M E$ is by far the preferred form to the favoured Chancery $<y>$ (items 36,154 ). Davis writes that many fifteenthcentury texts employ both $<\mathrm{y}>$ and $<\mathrm{g}>$ ("Grammar and Spelling" 504), and that $<3>$ as lost as early as 1400 .

While the orthographic trend towards the modern $<\mathrm{g}>$ is easy enough to decipher, exactly when the pronunciation shifted towards the $[\mathrm{g}]$ in the London speech community which gave rise to the eventual standard is hard to pinpoint. At some point in the fifteenth century, perhaps even during the shift from $\langle 3\rangle$ to $\langle\mathrm{y}\rangle$, [g] was adopted into standard speech. Upward and Davidson claim this happened by 1500 (44) and Samuels calls ayenst a "non-standard" form in late fifteenth-century London ("Spelling and Dialect" 51). Benskin, however, writes that it "remains to be determined" when yeuen was displaced by the modern giuen, which only had a "foothold" in the 1480's, and he is under the impression that yeuen remained standard into the next century ("New Perspectives" 81). The best contemporary reference of the sound change is the famed confusion for "egges" and "eyren" in Caxton's Eneydos prologue. The variation between these two lexical items is a morphological confusion (in the plural -es and -en endings) as much it is phonological, but the anecdote nevertheless illustrates that [j] and [g], at least in some cases, were still recognisable allophones of /g/ in the late fifteenth century. From the surviving evidence, it appears that [j] has certainly declined as a widespread variant in the mid fifteenth century, although $<\mathrm{y}>$ is still the preferred grapheme by Chancery clerks. 
The question of just whether the change was orthographic or phonological remains to be solved, and it is hoped that the pattern of variation within the texts of de Worde and Pynson will help to clarify this issue.

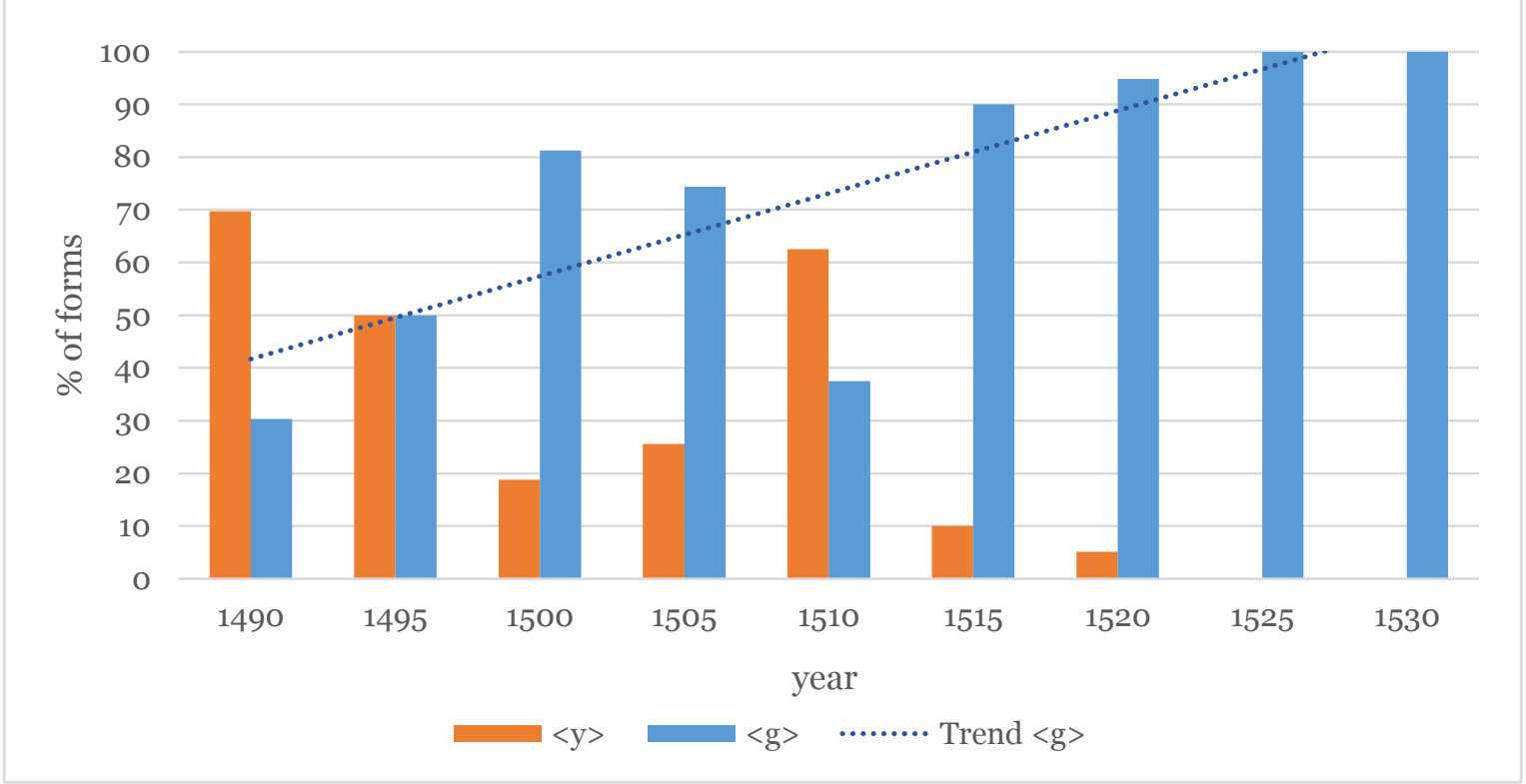

Fig. 2.3. Spelling of /g/ in Richard Pynson.

The development towards $<\mathrm{g}>$ is marked, rapid, and ultimately comprehensive. The decline of $<y>$ is almost immediate, and although there is a notable increase in 1510 (a year which has been problematic across a number of forms studied), the rapid shift back to $<\mathrm{g}>$, complete in ten years without a single $<\mathrm{y}>$ form observed, indicates that this text is an anomaly. It is worthwhile to note that of the $20<y>$ forms found in the 1510 texts, 18 of them were from the Text A, while Text B had just 2 examples alongside $11<\mathrm{g}>$. Although the 1510 Text A was a contemporary work, the author (Richard Guildford) would have been in his late fifties when he wrote it (DNB "Guildford, Sir Richard"), and considering the history of the text (in the appendix) it is very likely that Pynson's house would have worked from the authorial manuscript. The surviving examples of $<y>$ graphemes in adjacent texts, although much fewer, nevertheless show the earlier grapheme was still an accepted variant, and is at times preserved from the copy-text. Of all post-1500 texts in Pynson's corpus, just two (1510 Text A and 1505 Text A) had majority $<y>$ forms. From the data gathered, it can be stated with strong confidence that the $<y>$ grapheme, which was the dominant form in 1490 , is a minor variant in 1500 , and by 1530 has vanished completely from Pynson's texts. 


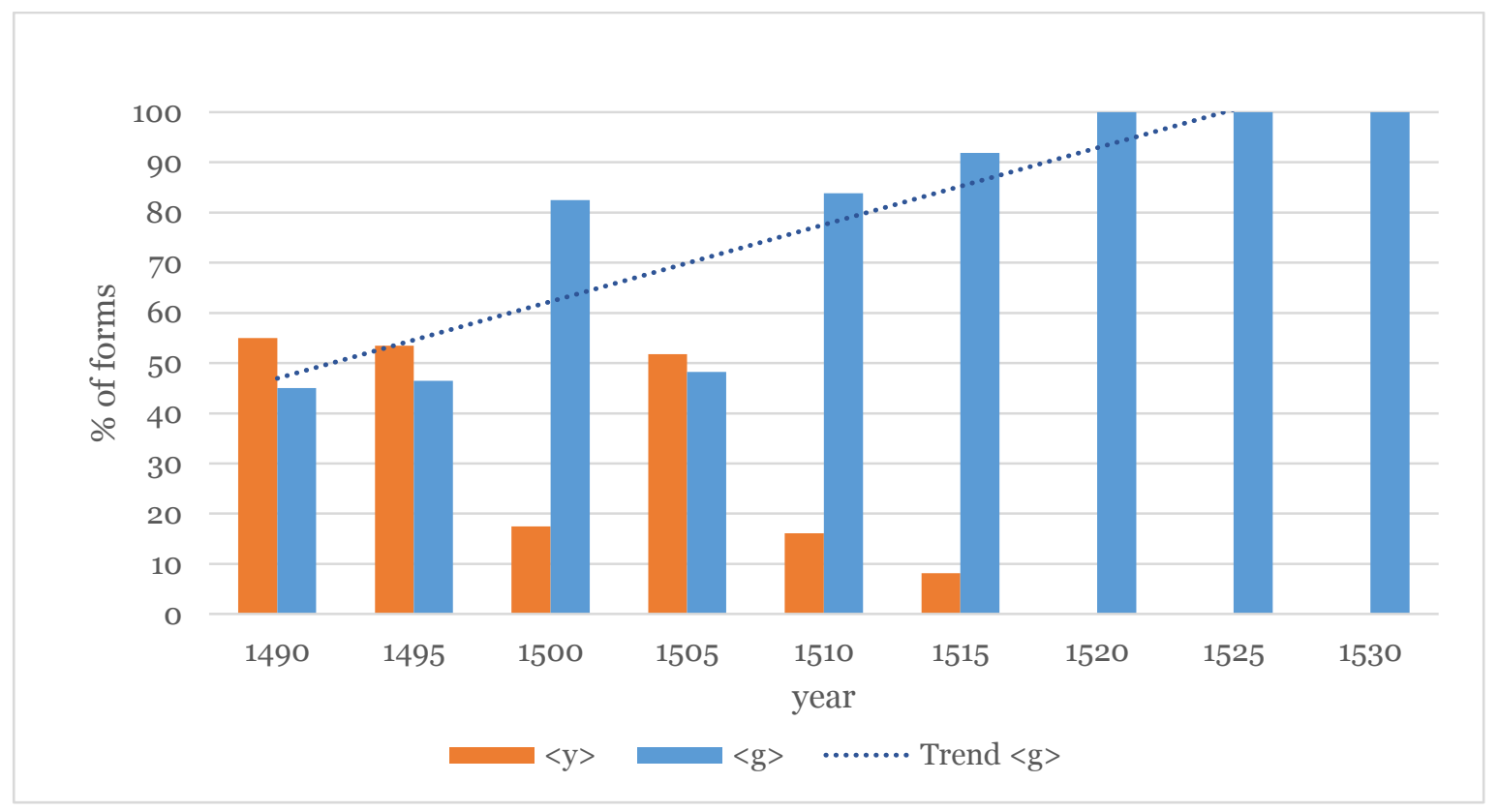

Fig. 2.4. Spelling of /g/ in Wynkyn de Worde.

The development to $\langle\mathrm{g}>$ is an interesting case where de Worde's texts happen to be the more linguistically advanced. As in Pynson's works, the sample texts here signify a period where the data shifts dramatically. This is localised to a particular text, namely the 1505 Text B which has 26 examples of $<\mathrm{y}>$ and 14 of $<$ g $>$. The copy-text of the 1505 Text B was printed in 1493, a time when the $<y>$ variant was still common (compared to the 1505 text A, which was composed in 1504). Aside from this irregularity, what follows is a nearperfect development to $<\mathrm{g}>$, complete in 1520. As in Pynson's works, it is quite clear that the $<y>$ grapheme in de Worde, which was minor preference when he first began to print, very quickly declined, and for all practical purposes, disappeared well before de Worde's death.

Unlike a number of other orthographic changes, which can be divided quite comfortably into 'classes' of lexical items which change at different rates (such as the medial $<\mathrm{d}>$ and $<\mathrm{th}>$ ), the use of $<\mathrm{y}>$ and $<\mathrm{g}>$, which in itself is only found in a few terms (largely again and give, with their variant grammatical forms), appears to be indiscriminate. Pynson's 1490 Text B, for example, has 6 examples of ayen alongside 4 of agayn, and 11 examples of yeue, and 11 of gyue (including forgyve, gyuen, etc.). These forms are also not found in complementary distribution throughout the text, which could suggest a different compositor or proofer may have been at work; yeue and gyue are found alongside one another in the same page, paragraph, and even sentence. The sample texts with this distribution do not favour one form in a particular context - it one of the few examples of variation which appears to be, before 1500, totally irregular. As this form lacks any coherent pattern, is found most commonly in texts composed when the use of $<y>$ was at its height, and declines so rapidly, it is reasonable to conclude that within this 
speech community, at least, there was no perceptible phonetic variation between [j] and [g], the change was completed sometime before Pynson and de Worde began to print, and the grapheme $<\mathrm{g}>$ was established as the sole form for this phoneme between 1520 and 1525 .

\section{$\mathrm{ME} / \varepsilon: /($ mete and ese to meat and ease)}

$\mathrm{ME} / \varepsilon: /$ is a phoneme which experienced significant change in the GVS, raising first to /e:/ and then merging with /i:/ from original /e:/ between the fifteenth and eighteenth centuries. ME / $\varepsilon$ :/ also exhibited a significant shift in spelling, with the grapheme $<$ e $>$ steadily replaced by <ea $>$ by the end of the sixteenth century. Scholars who have studied both the orthographic and phonological processes tend to assume the <ea> grapheme represents this phonetic raising (Freeborn 361; Upward and Davidson 176). Documenting the many complex changes with various groups of words inside this phoneme (such as the raising to /e:/ and merge with /i:/, the merge with /æ:/, the raising of / $\varepsilon: \mathrm{r} /$ ) would require a breadth of research and analysis beyond this study, and therefore I have chosen to focus on the group of words with $\mathrm{ME} / \varepsilon$ :/ which raise to /e:/ and then /i:/; one half of the meat/meet merger, the phonetics of which is covered extensively in all good books on the history of the English language.

There is a considerable wealth of material on the GVS, with a general consensus achieved on the overall process of development, and it is unnecessary to undertake a comprehensive review of such an extensive study. At the start of the sixteenth century, ME $/ \varepsilon: /$ is still realised as a half-open vowel, and in a number of advanced and non-standard speech communities, raised to /e:/ in the course of the century (Barber 107). Completely unambiguous raising of $/ \varepsilon: /$ amongst prestige speakers, indicating the final stages of a sound shift, does not occur until the second half of the seventeenth century (Lass, Cambridge Vol. 3 84). The merger of this newly raised /e:/ with /i:/ (giving us the PresE pairs meat/meet and beat/beet) is heavily varied according to different speech communities. Some non-standard forms of English, including non-standard London speech, recognised /i:/ as early as late ME (Barber 107), and the merger of meat:meet can be assumed for many forms of "lower-class" and "informal" speech in the fifteenth century (Görlach, Early Modern English 69). In prestige and standard speech however, the full merge with /i:/ was apparently not complete until the eighteenth century (Lass Cambridge Vol. 3 98). The development of ME / $\varepsilon$ :/ is not a simple chain of events that can be sectioned into various 'stages' - even this description is a generalised outline of the heavy variation that progressed and stabilised over the course of several centuries. We can, however, claim with confidence that during the early sixteenth century, this phoneme 
would still be recognised as $/ \varepsilon$ :/ in the London speech community to which Pynson, de Worde, and most of their printing house, most likely belonged.

The shift to <ea> spelling in this section of $\mathrm{ME} / \varepsilon$ :/ is one part of the general introduction of the <ea $>$ grapheme, discussed at length in a number of texts. Although some words were spelled <ea> in OE, such as meal, bean, and dream, the grapheme did not survive into ME and was lost shortly after the Norman Conquest. There is no real relation between this lost spelling and the return of the form some centuries later. There is a certain level of disagreement over the precise introduction and early spread of <ea > in the fifteenth century; Davis notes the spelling "became fairly common in the latter half of the fifteenth century" in his study of the literature ("Grammar and Spelling" 500). Scragg claims the grapheme, an Anglo-Norman borrowing, was introduced by the Chancery scribes and became "increasingly popular" throughout the second half of the fifteenth century, and "though it disappears almost completely in the work of the early printers, by 1550 it is as fully established in printed material as it was in manuscripts of a century earlier" (67). He also makes an interesting point that the spelling "first occurred most frequently in words which were common to Anglo-Norman" and was only later "extended to native words with Middle English / $\varepsilon$ :" (48-9).

However, Fisher rejects this assertion; "the increasing use of ea in words like reason and measure noted by Scragg is not at all apparent in any series of government documents... Occurrences of the ea in words like reasonably and treason are exceptions" (Chancery English 28). One of the "most remarkable features" Blake notes in his study of Reynard is "how the grapheme ea appears suddenly and becomes accepted as the standard spelling in some words in such a short time" (68). Görlach labels the use of this grapheme as a "pre-Caxton convention" disrupted by the early foreign printers, which was nevertheless well established by 1520-1550 (Early Modern English 46). Upward and Davidson claim attempts were made to recognise the <ea $>$ grapheme as a representation of $/ \varepsilon$ : / at "the end of the fifteenth century" although "actual practice was far from consistent" (176). Although there is some argument over the exact introduction of the grapheme, and several frankly incorrect evaluations of the <ea> grapheme within early printing, a rough timeline can be drawn from this collection of assertions. The grapheme was found (however rarely) late in the fifteenth century, spread rapidly in the early sixteenth century, and by 1550 was a recognised form. The contribution of Pynson and de Worde to this development, and the relationship between the grapheme and the phonetic shift, still need to be considered. 


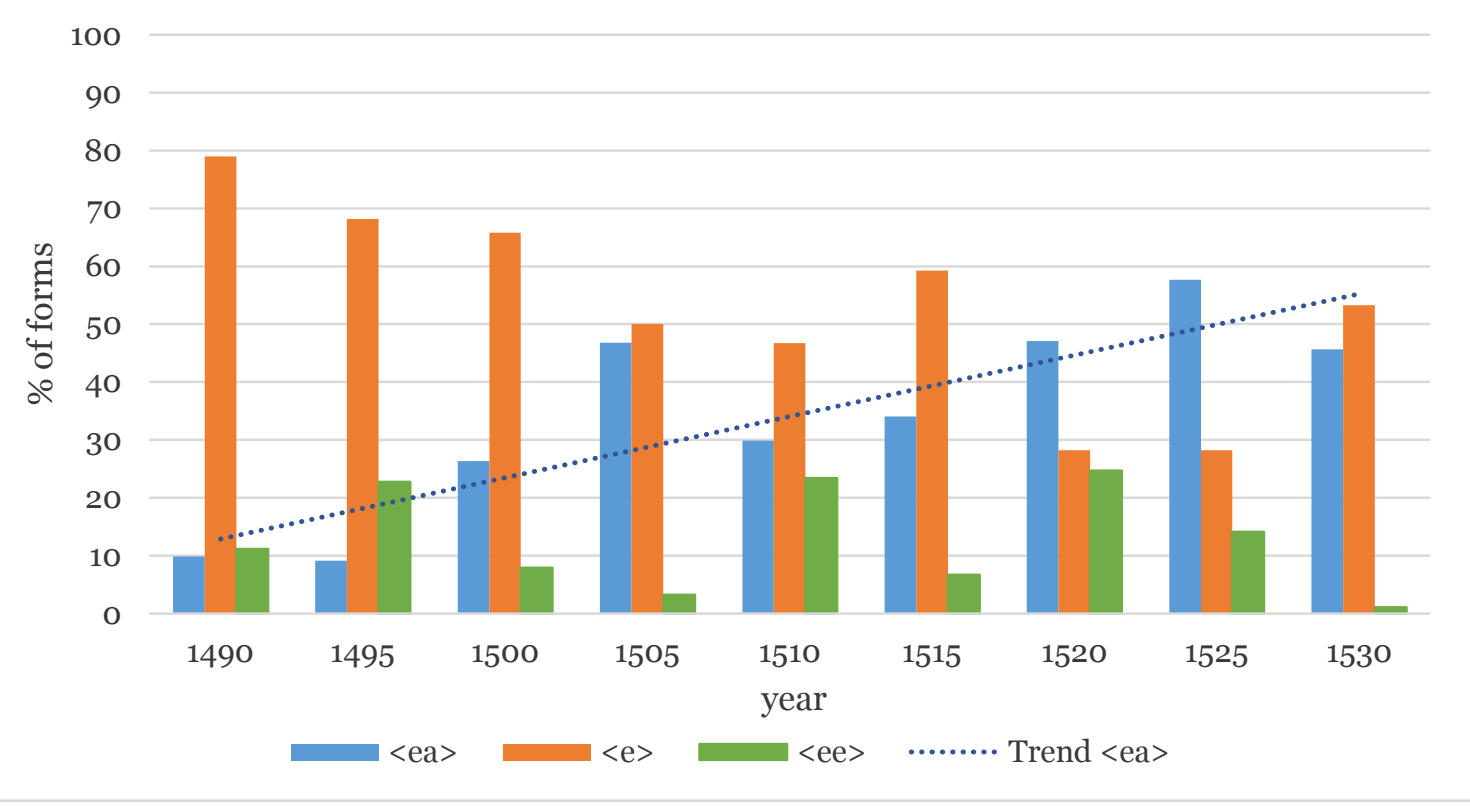

Fig. 2.5. Spelling of $/ \varepsilon$ :/ in Richard Pynson.

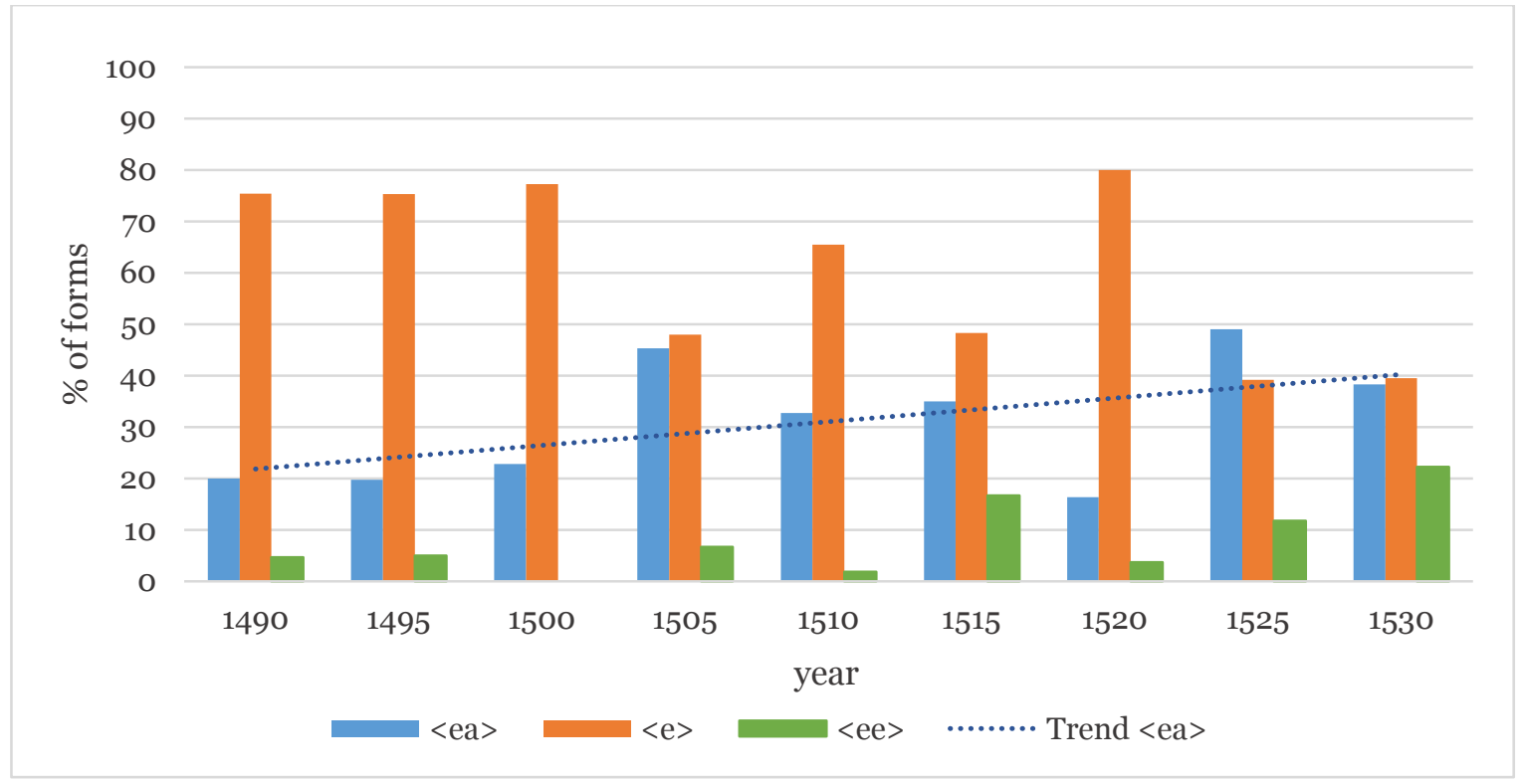

Fig. 2.5. Spelling of / $\varepsilon$ : / in Wynkyn de Worde.

It is interesting to note the overall similarities in the spread of forms across the two printers for this period. Although the <ea> grapheme becomes more regular during the studied period, it is not quite enough to displace $<$ e $>$ as the majority variant. The most notable shift occurs in 1505, visible in the works of both printers as the occurrence of <ea> rose approximately 30\% in just five years. The only significant outlier is de Worde's 1520 Text A, which only has one example of <ea> (treatise), and is admittedly quite a short text in itself. While the general trend towards the <ea> can be noted, there is however, a significant pattern to this varied distribution of forms. What follows is a detailed analysis of this spelling, with each word separated into two categories; the first are those of $\mathrm{OE}$ 
origin, such as meat, eat, speak, and read. The second are those borrowed into English during the ME period, either from Norman French, or occasionally from Latin. Such terms include beast, feast, preach, treason, and decrease. The minor third alternative <ee $>$ is comparatively sporadic, and in Pynson's works has essentially vanished by 1530 . While there is a slight increase in de Worde's texts it is never more than a very minor form, and therefore is not graphed or included in further analysis.

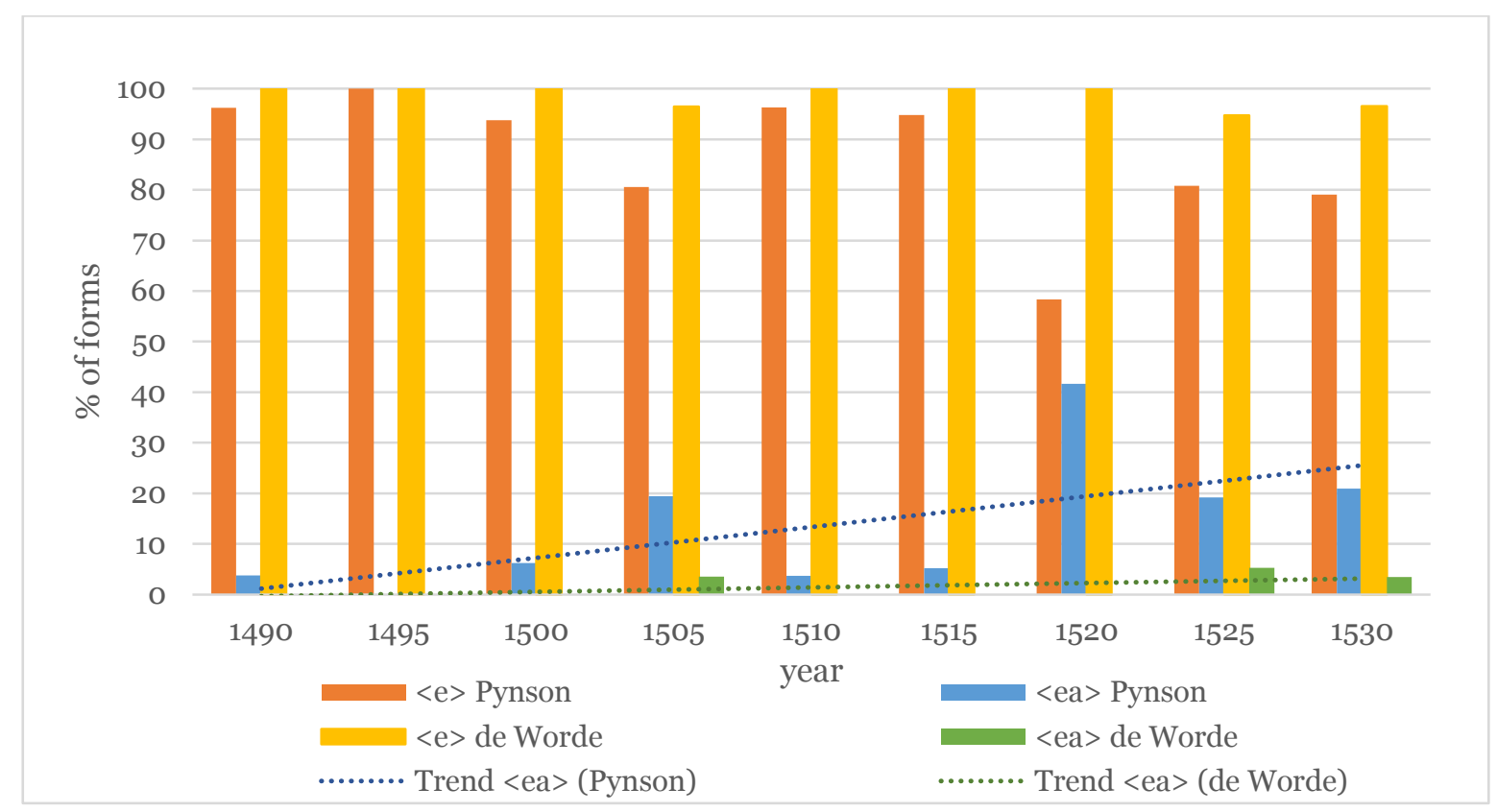

Fig. 2.7. Spelling of / $\varepsilon$ : / in words of OE origin in Pynson and de Worde.

This graph immediately shows that the <ea> grapheme in OE origin words is significantly low. Although there is a gradual increase of <ea $>$ in Pynson's works after 1510 , there is a clear preference for the earlier <e > grapheme, particularly in de Worde's texts. The only notable irregularity in the data is the contraction in Pynson's 1520 data, when meat, ease and mean were rendered with the <ea> grapheme. Interestingly, of the twenty-five examples of OE origin words containing <ea> from 1515 onwards, twenty are from words written chiefly as $\langle æ>$ in the OE period before the grapheme was replaced with <e>: sea, mean, and meat are three prime examples. This trend continues in 1525 and 1530, with only one example of mete and one of ese in 1530, illustrating a shift towards the modern <ea> grapheme - however, it is far from complete and the <e> variant remains dominant in this class of lexical items. 


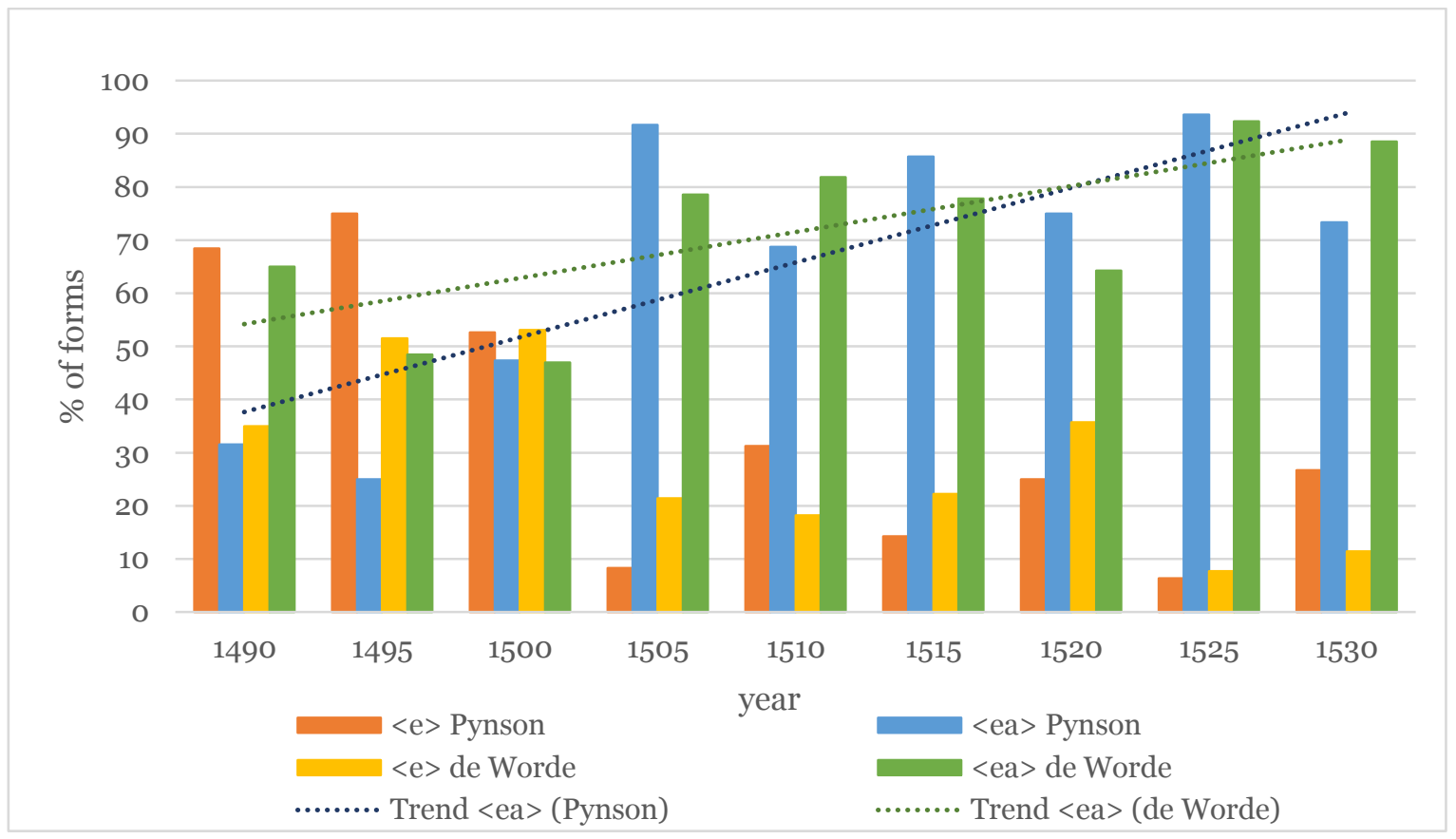

Fig. 2.8. Spelling of $/ \varepsilon$ : / in words of ME origin in Pynson and de Worde.

The <ea> grapheme in ME origin words, however, increases dramatically throughout the period across both printers, while the $<$ e $>$ declines to a minor form. Despite Fisher's confident rejection of any instances of <ea $>$ in the fifteenth century, Scragg's assertion that the form was first found in French loan words before 1500 appears to be quite correct. Pynson's texts express some fluctuation, but there is certainly a significant shift towards the <ea> as the majority form, particularly in 1495-1505, where the use of ME-origin <ea> increases by 66\%. De Worde's shift to <ea> is less uneven and more comprehensive, with the sharpest contrast in data being a 30\% increase in the years 1500-1505. Although there is a contraction in 1520 (similar to Pynson), this is followed by an increase in 1525 and stabilisation in 1530, indicating that <ea> is established in de Worde's later works. One interesting pattern to note is the likeness between the spread of the <ea $>$ grapheme in ME origin words, with the same overall shape reflected across both printers: Pynson and de Worde both have a point of change dated to 1500 , and both decline in 1520 and increase again in 1525. This indicates that the change is most likely not the result of a single compositor or proofer, and (with the exclusion of the unstable 1490's) it seems to be adopted by both printing houses at similar times with similar fluctuations and rates of growth.

The broad data in itself illustrates a notable trend towards the modern <ea $>$ in the works of two printers, superficially confirming the assumptions made by both Freeborn and Upward and Davidson that the grapheme represents the raising of $/ \varepsilon: /$ to $/ \mathrm{e} / \mathrm{s}$ However, further analysis shows that the vast majority of <ea $>$ forms are found in words of ME origin. It is extremely difficult to convincingly attribute such a cleanly divided shift 
to sound change. There are two other factors to consider when making this evaluation; firstly, the actual sound change in the speech community to which Pynson and de Worde most likely belonged was among the slowest to adopt this raised phoneme as standard speech, with Lass dating the change to the seventeenth century (Cambridge Vol. 3 84), and most other scholars agreeing that the raising was limited in the sixteenth century to informal and non-standard speech. Secondly, the idea of <ea> as a graphemic representation of /e:/ is in itself confusing. Although there was nothing resembling the precise terminology of the twentieth century in the description of vowels, the works of the sixteenth-century orthoepists nevertheless indicate a working understanding between the shape of the mouth and the resulting vowel sound; Hart, one of the earliest orthoepists in 1569 , describes the spellings $<$ a $>$ as a "wyde opening... as a man yauneth" and $<$ e $>$ "with somewhat more closing the mouth" (Lass Cambridge Vol. 3 61). To suggest that a grapheme (such as <ea $>$ ) containing $<$ a $>$ could phonetically represent a raising defies this intuition. There are examples of <ea $>$ that now resemble accurate portrayals (such as the $/ \varepsilon: /$ in steak and break, which began its shift to the <ea> spelling the early sixteenth century), but none are in the process of raising during this time. When all evidence is considered, it is almost impossible to regard the increase of the <ea> grapheme as a phonetic representation of raising / $\varepsilon$ :/.

The most likely explanation for this spelling stems from the conclusion drawn by Scragg; the sound is an Anglo-Norman borrowing, initially found in French loan-words before spreading to the OE spellings. This analogical process is quite natural and can be seen in other French vowel combinations that crept into English during the ME period, such as $<\mathrm{au}>$ and $<\mathrm{ie}>$, which extended to include OE words with similar sounds (for example as aught (OE æht) and thief (OE ðeof)). This notion is decisively confirmed with the evidence gathered from the texts of Pynson and de Worde; of the 444 examples of ME $/ \varepsilon$ :/ before the /i:/ merger found across 36 texts, 402 belonged to words with ME origin. Of the remaining 42 examples, 30 were found between the years 1515 and 1530, demonstrating an emerging trend towards <ea> spellings with OE origin words. On a simpler level, this analysis clarifies the uncertainty surrounding the introduction and spread of the <ea> grapheme in the late fifteenth and early sixteenth century. It does not disappear "almost completely", (Scragg 67) nor do Pynson and de Worde "disrupt" the development from a "pre-Caxton convention" (Görlach Early Modern English 46). What we see is a minor form with $14 \%$ of all examples in 1490 , increasing steadily to $42 \%$ in 1530, with a clear, consistent pattern of distribution based on etymology. 


\section{ME Nasal /a/ (lond to land)}

The variation in spelling ME /a/ can be traced back to the OE period, when "short stressed vowels had their duration increased before sonorant initial consonantal clusters whose elements shared an approximate place of articulatory gesture", and $<0>$ came to be seen alongside $<$ a $>$ spellings (Jones 25). The $<0>$ variant is certainly prevalent in OE from an early date (Upward and Davidson 34), but exactly when this shift occurs is difficult to pinpoint. Lass argues the vowels lengthened in the ninth century (The Shape of English 125), while Jones finds homorganic lengthening in the Lindisfarne Gospels (31). The justification for spelling this sound with $<0>$ instead of $<a>$ is generally attributed to rounding (OED "hand, n."). The grapheme <aa>, comparatively rare in OE, did not survive the period, and there appear to be no examples of <aa> before any nasal consonants outside of Biblical proper nouns $(D O E)$. In ME, $<0>$ is the majority form - for example, it accounts for $75 \%$ of extant instances of lond (eLALME 183; MED "lond, n."). After surviving as a minor variant for centuries, the $<$ a $>$ variant began to increase steadily through the fifteenth century; 69 of $113<$ a > spellings in land recorded in the MED are found after 1380. Conversely, 113 of $265<0>$ spellings were found after 1380, indicating that this increase in $<a>$ is not necessarily matched with a decrease of $<0>$, and even throughout the first half of the fifteenth century, $<$ a $>$ is still considered a variant form (MED “lond, $n$. .).

The vowel ME /a/ rose at some point during the GVS, although the exact dating of such a change is disputed. Kökeritz suggests that the development from ME /a/ to [æ] was "rapidly gaining ground" during the fifteenth century, and became accepted in "polite circles" at the end of the sixteenth (162). Zachrisson, citing (rare) examples of ME /a/ rendered $<\mathrm{e}>$ in words such as understende, and eny, also claims the sound had raised in the fifteenth century (58). However, Dobson claims ME /a/ rose to [æ] only in vulgar or dialectal speech during the fifteenth century, "in less careful StE in the late sixteenth century, and in correct educated English to an increasing degree during the seventeenth century" (548). Lass notes the earliest description of a raised vowel for ME /a/ does not occur until c. 1617 , and is even still probably a minority pronunciation until the midcentury (Cambridge Vol. 3 86).

Within Chancery, <a> spellings are recorded as the majority form for most significant pre-nasal lexical items. As the transcription of nasal $\langle 0\rangle$ and $\langle a\rangle$ is pointed out by Matheson as sometimes being erroneous (648), a certain level of caution must be applied to the Chancery evidence. For a number of lexical items, however, the preponderance of one variant puts the result beyond statistical error: any (105 to 16), hand (19 to 4), and husbond (no <a> examples). There are several minor examples of <e> in this position, the most common being eny, which had 109 examples, compared to 130 of 
any (Fisher 310-385). This preference for $<\mathrm{a}>$ is not necessarily matched in contemporary non-official documents - for example, both the Winchester MS of Le Morte D'Arthur and Gregory's Chronicle note a majority <0> spelling before nasals (Fisher and Bornstein 192, 199). The Paston letters, depending on the word, prefer one or the other; stand and hand prefer $<\mathrm{a}>$ forms, but lond, ony, and husbond tend towards $<0>$ (Davis, Paston Letters). This suggests that while some words had majority $<\mathrm{a}>$, this variant was still far from comprehensive within manuscripts and personal letters as it is within the official Chancery documents. The early diffusion of $\langle a\rangle$ and $\langle 0\rangle$ forms in the fifteenth century are inconsistent with phonetic changes that occur from below (such as the variation of $<\mathrm{d}>$ and $<$ th $>$ for intervocalic $/ ð /$ ), casting doubt on the theory that it represents a raising to [æ]. It is quite likely that [æ] did already exist as a very advanced minor form in the fifteenth and early sixteenth centuries; it is very unlikely, however, that the professional Chancery scribes were reflecting the spelling patterns of lower-class, dialectal speech.

Within the early printers themselves, there is some material on the variation between $<\mathrm{a}>$ and $<0>$ before nasal consonants. Fisher observes an "interchange" between the two forms in his study of Caxton's texts, and also that ony is one of the rare, nonChancery forms that Caxton used consistently throughout his works (166). Blake also identifies an interchange in Caxton's editions of Reynard the Fox (66). There is not enough evidence in de Worde's print to gather conclusions, but Blake perceives a "marked preference for the $o$ spellings" in Pynson's edition (67). Horobin marks a strong difference between Pynson and de Worde in the spelling of any and ony in the Canterbury Tales: de Worde consistently followed Caxton's use of ony, while Pynson replaced the < $<>$ spelling with any (Chaucer Tradition 85-6). Existing evidence, and the conclusions drawn by Fisher, Blake, and Horobin suggest that either $<0>$ will still be prevalent, or that there will simply be a patternless interchange between both forms. (Many, rendered many or meny in Chancery, was already written entirely with $<$ a $>$ across all texts and for the purposes of this study is excluded). 


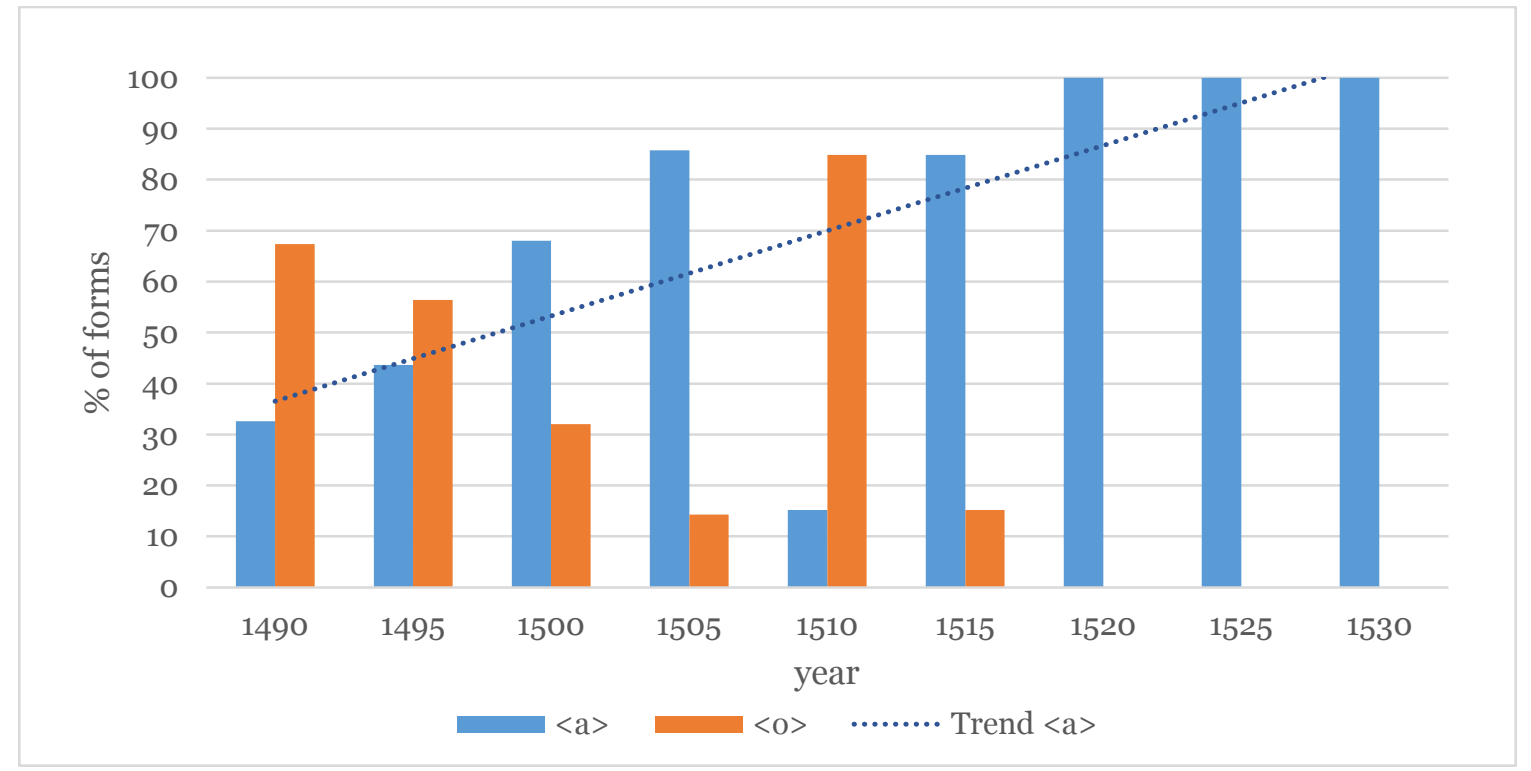

Fig. 2.9. Spelling of nasal ME /a/ in Richard Pynson

It is immediately obvious that the conclusions drawn by Blake and Fisher do not apply to this data. Pynson's shift to <a> is comprehensive, with an obvious decline from the outset and no $<0>$ forms identified after 1515. Pynson's 1510 samples, however contain a contrary amount of $\langle 0\rangle$ forms, at the expense of the $<a>$ variant. This is not easily attributed to the nature of the texts in question or repetition of lexical forms so much as it is an issue of the actual printing; 1510 as a whole is a remarkably conservative year for spelling in both of Pynson's sample texts (see below). However, in $1515<\mathrm{a}>$ becomes the dominant form once more, and by 1520 is the sole variant, a trend carried through the rest of the period.

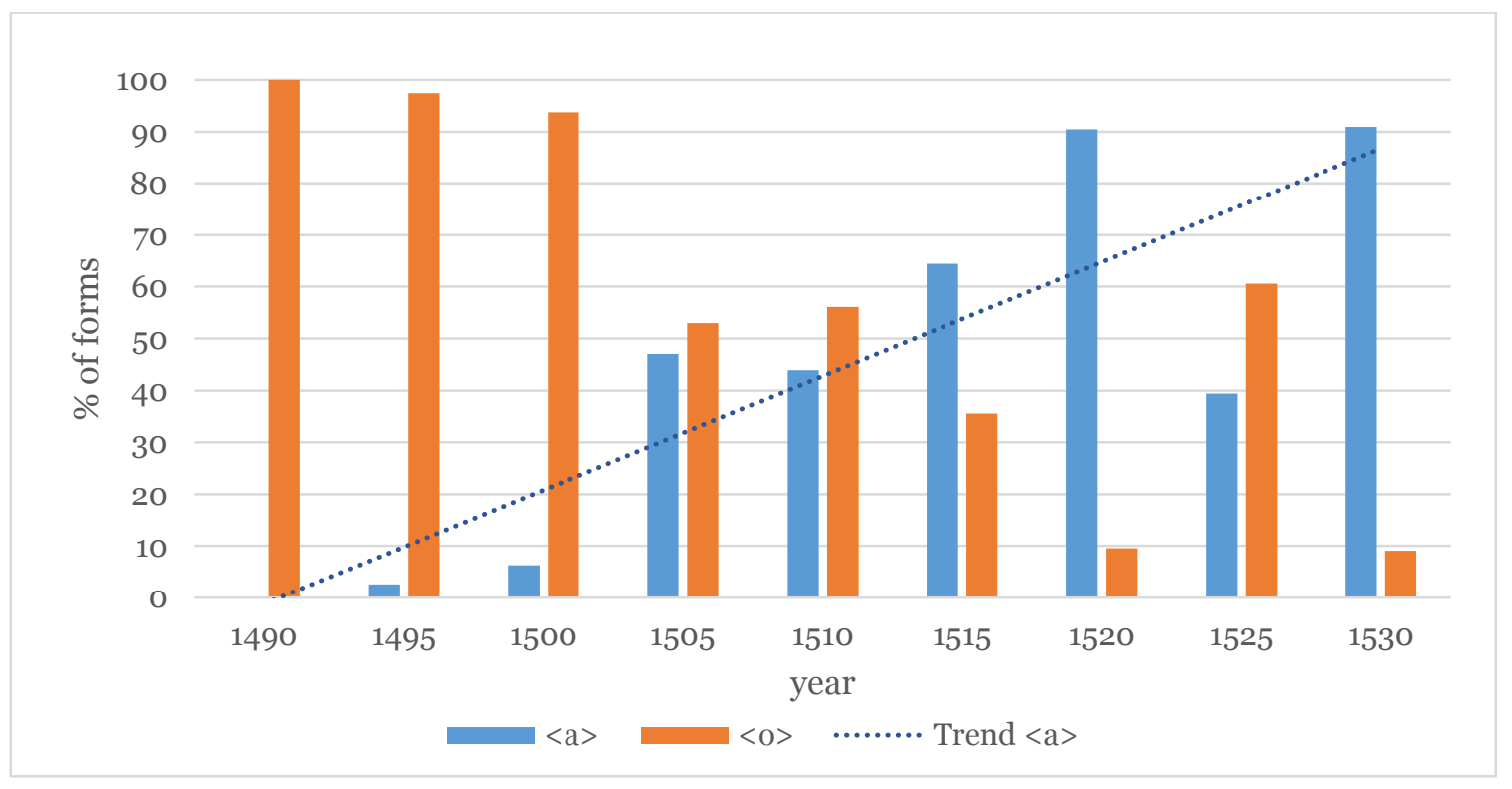

Fig. 2.10. Spelling of nasal ME /a/ in Wynkyn de Worde

It appears that at least for the first decade of production, Caxton's distinctive $<0>$ variants persists as the standard within his successor's house. There are no observed 
examples of nasal <a> in 1490, and only one in 1495 (stand in Text B). Between 1500 and 1505 , however, the number of $<0>$ forms decreases dramatically, and by 1520 , the two variants are almost entirely reversed. This idiosyncratic spelling, is, for at least the first fifteen years, one of the most visible distinctions between the houses of Pynson and de Worde. De Worde also has a curious irregularity in his otherwise reasonably steady trend from one majority form to the other in his 1525 evidence. Rather than an "interchange" between $<\mathrm{a}>$ and $<\mathrm{o}\rangle$, there is instead a distinct tendency towards a specific form based on lexical content. Of the 20 examples of $<0>$ in 1525, 17 are for the word ony, and 3 for stond. Conversely, there were no <a $>$ variants for any, and only 1 for stand. The other 12 $<$ a $>$ examples, such as band, hand and wander (the latter still pronounced /a/ in early sixteenth-century standard speech) had no <o> variants. Such spelling would have doubtlessly been perceived as regular by those at the press even if they are not entirely certain of the phonetic quality.

With these two irregularities aside, what we see is a clear shift from the distinctly archaic < $<>$ spelling of nasal ME /a/ to the emerging < a > variant, which is either complete or nearing completion in 1530 . There is still a certain level of variation typical of any recent language change, and as the $<$ a $>$ form does not gain a real foothold into nonofficial written English until the latter half of the fifteenth century, it is very recent. Although it is to some extent still open to interpretation, examples of $<0>$ forms during the short period of change reflect a distinction between these two spelling variants based on lexis and is in this regard quite regular.

\section{Ca. 1500 /o:/ and /u:/ (stoon and moost to stone and most; gode to goode)}

As with the majority of long vowels in the medieval period, the development of c.1500 / $\mathrm{s} /$ and /u:/ is problematic to define. The instability in spelling long vowels in the $\mathrm{OE}$ and $\mathrm{ME}$ periods and the development of the vowels themselves complicates the relationship between phonology and orthography, leading to a number of problems, the exact nature of which is still unclear. The method by most scholars has been to discuss the doubling of $<0>$ indiscriminately and for the initial discussion, I shall continue to do so here, before forwarding my own possible interpretation on differentiating the variant forms.

The written representation of vowel length in the OE period was at times confusing -although scribes marked a Latin apex over certain vowels, this was more often than not used to indicate stress rather than length, or to avoid ambiguity between two direct pairs, such as gód (good) and god (God). The doubling of vowels is a form found mostly in early OE manuscripts (Quirk and Wrenn 9). Interestingly, OE is the only period in which 
doublings are distributed relatively evenly across all five vowels (Conner 98). The c.1500 / : / (as seen in words such as gone, stone and done) was first realised as /a:/ in OE, and as a result spelled with $<\mathrm{a}>$ (and occasionally $<\mathrm{aa}>$ ) (Anderson and Jones 76). Meanwhile, c.1500 /u:/ was initially /o:/, and written in OE most frequently as <0> (Quirk and Wrenn 12). the DOE, for example, lists just 11 instances of foot alongside 830 of fot (including plurals and inflections) (DOE "foot", "fot", "fota", "fotes", "fotum"), and common lexical items containing $\mathrm{OE} / \mathrm{o}$ / such as mona (moon) and sona (soon) have no examples of $<$ oo $>$ at all.

$\mathrm{OE} / \mathrm{a}: /$ rose and rounded to $/ \mathrm{o}: /$ in the twelfth century, reaching relative stability a century later (Lass, History of English 63). ME / $:$ : came to be realised as <0 $>$, with $<00\rangle$ a very minor variant. Surviving evidence suggests that by the fourteenth century, $<0>$ had displaced the earlier spelling in the south, with almost all $<\mathrm{a}>$ forms (illustrating the former OE /a:/) largely limited to northern texts (MED "bōn" n., "stōn" n., "mōst" adj.; eLALME, items 175, 220), and while the OE /a:/ is still preserved in the north, the change to /o:/ is certainly in progress (Görlach, Early Modern English 64-5). There was little development of /o:/ in the early ME period, however, as < $<>$ spellings continued to dominate as the majority variant. The rising of $/ \mathrm{s} /$ meant that the form shared its spelling with ME /o:/ making the difference between /o:/ and /u:/, marked in OE orthography, becomes indistinguishable in written ME (Burrow and Turville-Petre 10), and pairs such as boot and boat were distinguished by context.

The late ME period saw further shifts in the written status of / :/ and /o:/ towards their eModE forms. In the late fourteenth century, the grapheme <oo > began to appear in lexical items containing both /o:/ and /o:/, and is the preferred form in Chaucerian English (MED "gōd" adj., "mōne" n.1., "mōst" adj., "stōn" n.). Although a few lexical items, such as good, appear to have slightly more <oo > examples in the fifteenth century, there is no discernable pattern of usage between either phoneme. A second development was the loss of final [ə] which after the fourteenth century was no longer pronounced, and words such as /na:me/ became /na:m/. Final <e > was then utilised (initially very haphazardly) as a marker of vowel length (Upward and Davidson 178; Scragg 79). Finally, at some point in late ME, probably in the first few decades of the fifteenth century, ME /o:/ rose to the close back vowel /u:/, predominantly in non-northern provinces, and was complete by 1500 (Lass, Cambridge Vol. 3 66, 79). ME /0:/ and /o:/ shared two variants, <o > and $<00>$ with sporadic use of final $<\mathrm{e}>$. This variation is seen in the Chancery documents, where the alteration between $<0>$ and $<00>$ shows the system is far from stable; done, for example, is spelled done 12 times, don 16 times and doon 36 times (Fisher, Chancery English 331). Comparatively, good (59 instances) goode (20) gode (26), and even goude 
(3) serve as variants of good (344). The Paston letters contain examples of doune (done) and goud (good) alongside the traditional $<0\rangle\langle 00\rangle$ and final $<\mathrm{e}>$ spellings, and Lass states this peculiarity is due to the raising of /o:/ to $/ \mathrm{u}$ :/, often written $<\mathrm{ow}>$ and $<\mathrm{ou}>$ (Cambridge Vol. 3 66).

The subject of vowel doubling in the early printers and writers of the late fifteenth century is discussed by several scholars. Davis writes that the difference between close and open $o$ (in other words, close /u:/ and open-mid / $\mathrm{o} /$ ) was not shown in the spelling of most scribes ("Grammar and Spelling" 499). Blake treats development of items such as no and $g o$ in the various Reynard texts he studied as completely orthographic, with a tendency by Pynson to double the final single vowels, while de Worde shortens them (67). Mark Aronoff's study of Wynkyn de Worde's orthography is by far the most detailed work on this subject. When attempting to write de Worde's 'rule' on the spelling of long vowels, he concludes that "neither the practice of doubling vowels nor the practice of adding a final $e$ to indicate length is consistent enough to warrant canonization. We may assume that the compositor was familiar with both practices... but I don't think that we can go any farther" (95). At some point in the sixteenth century, the two phonemes achieved comparative harmony, with $<0>$ representing / $: /$, and $<00>$ representing / $\mathrm{u} / /$. It is apparent from the various comments on the matter that it is difficult to distinguish exactly when the change occurred, and if there was any sort of order to it.

Both phonemes have split, shortened, and shifted significantly since the fifteenth century, and a number of forms were included which no longer have PresE vowel correspondents, such as $/ \mho /($ good $)$ and $/ \Lambda /$ (blood) are included as they were yet to change (Lass Cambridge Vol. 3 187). Open-ended items such as no, go, and so are included as they contain the same / $\mathrm{u}$ :/ vowel, even if their development is treated differently by a number of scholars (the data collected showed that the pattern of vowel doubling of so/no and most/done was almost identical throughout the period). The final $<$ e $>$ was found at the end of most single $<0>$ words but generally not consonant clusters (such as ghost or most) and in some cases was found even at the end of <oo > variants, particularly before 1500. However, to keep this analysis as simple and clear as possible, the emphasis here is on the variation between $<0>$ and $<00\rangle$ as inclusive graphemes for the two phonemes /o:/ and /u:/. Other minor forms, such as goude, were negligible and found in single occurrences within a text, if at all, and therefore not included as a separate category for analysis, and the spelling <oa> (seen in boat and coat) did not appear until later in the sixteenth century. 


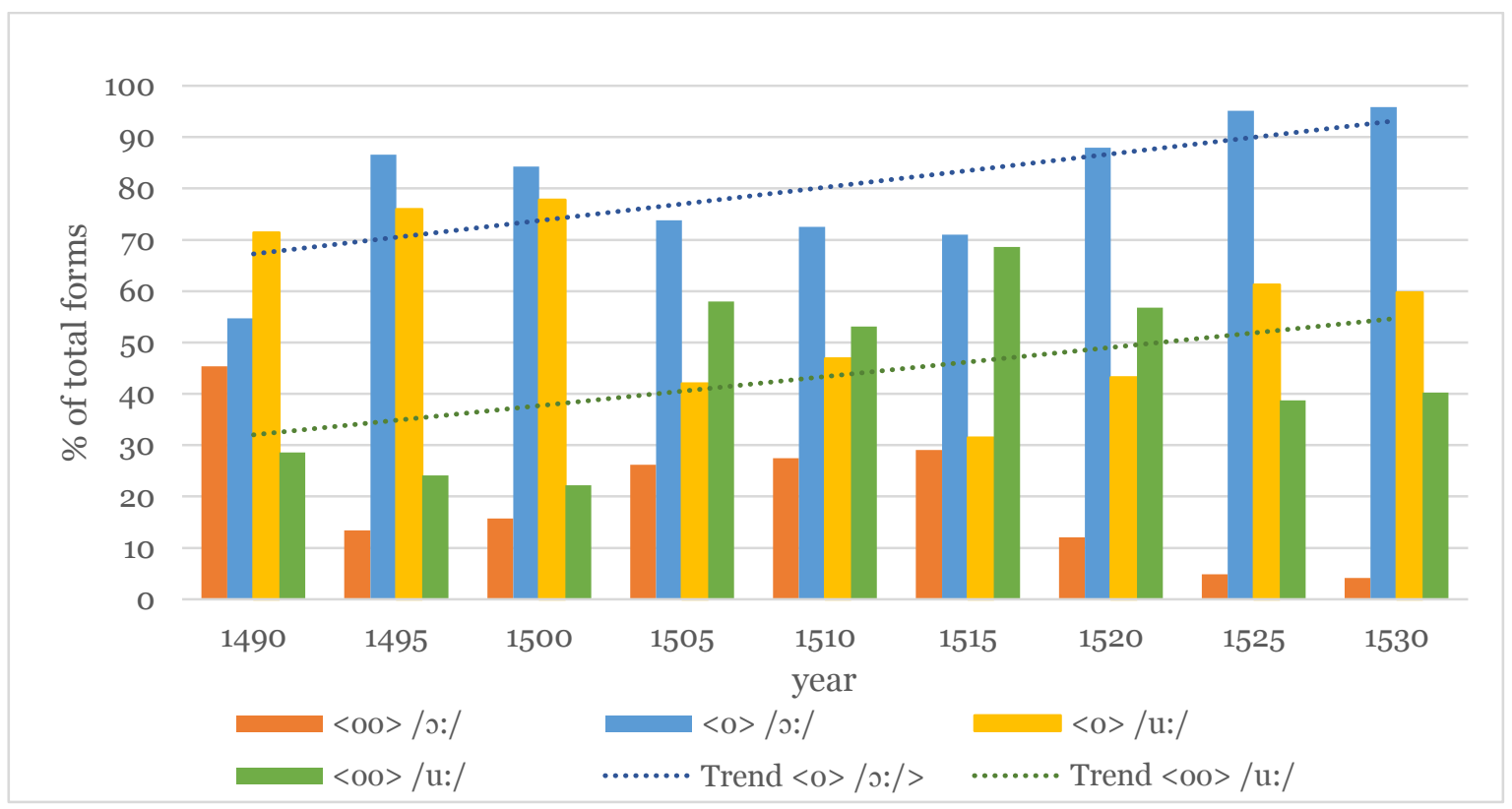

Fig. 2.11. Spelling of ca. 1500 / :/ and /u:/ in Richard Pynson.

Firstly, the development of open-mid / $\mathrm{o} /$ is trending consistently towards the modern $<0\rangle$. This change is essentially realised as early as 1520 , with $88 \%$ of all examples containing $\langle 0\rangle$, climbing to $95 \%$ and $96 \%$ in 1525 and 1530. Of these 12 instances of lingering $\langle 00\rangle, 10$ are the word moost, with one example of hoope and one of hoost. There are numerous $<0>$ spellings of these three words throughout the final two groups of texts, indicating that the variation in spelling of the open-mid / $/$ / had essentially vanished, and the modern variant was well established. Meanwhile, close / $\mathrm{u}$ // is significantly less standardised at the close of Pynson's career, and the <oo $>$ variant, while enjoying a brief period of clear dominance in 1515 , remains a minority form in 1530 . The vast majority of $<$ oo $>$ are of one particular lexical item, good, which accounts for 58 of the 63 examples found in 1525 and and 1530. The spelling of good does lead this change - in 1500 and earlier, the item is written most frequently with an $\langle 0\rangle$, and in 1505 , came to be spelled $<00>$. This does not mean that good is the sole lexical item to contain the <oo $>$ spelling a range of other words are found with <oo > spellings, such as soon, book and foot, but most examples are relatively few, and indicate that while $<00>$ spellings are acceptable, they are still far from the norm. 


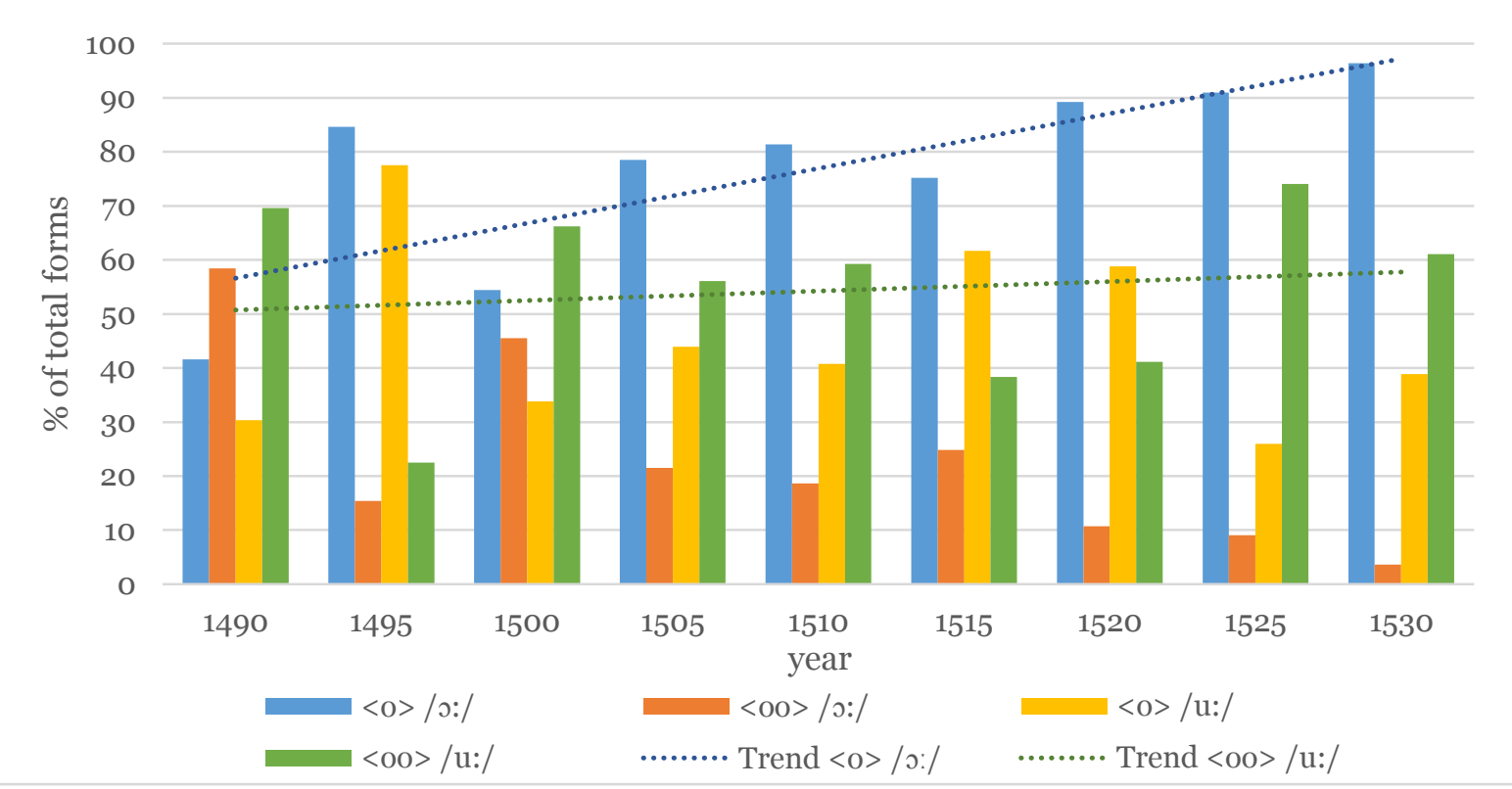

Fig. 2.11. Spelling of ca. 1500 / : / and /u:/ in Wynkyn de Worde.

The distribution of the / $\mathrm{o} / /$ and / $\mathrm{u}: /$ forms in the texts of de Worde, while bearing some resemblance to that of Pynson's texts, nevertheless has some striking points of difference. Most interesting are the 1495 texts, where the spellings are very close to regular, regardless of sound. This particular data point agrees with Aronoff's observations of de Worde's 1498 edition of The Canterbury Tales, which frequently changed the double-vowel spellings from the copy-text (Caxton's 1485 edition) to a single vowel (76). This change appears to be indiscriminate of vowel shape and height, but by 1500 , the tendency to spell /u:/ declined once more, and the brief attempt at standard vowelspellings was over. Aside from the 1495 irregularity, there is no perceptible connection in the spellings of these two separate sounds. The progression toward $<0\rangle$ in the / $/ 0$ / phoneme is reasonably steady with the only major inconsistency in the 1500 texts. This is due to the 1500 Text B (composed in the latter half of the fifteenth century, when such spellings were still common), which contained a number of <oo> examples disproportionate to contemporary spellings, such as what is found in 1500 Text A, and the 1495 and 1505 texts. By 1530, 96\% of / :/ spellings contained the modern < $>$ grapheme, with 9 remaining examples, 7 from Text A. 4 of these examples are moost, with doon, hooly, and foo (foe) also occurring. The Text B, contains just $2<00>$ instances of /o:/; loo and most.

Although the spelling of / $\mathrm{o}: /$ modernises and standardises quite strongly in the period studied, the second phoneme under analysis, ca. $1500 / \mathrm{u} / /$, remains somewhat static. Although de Worde expresses a tendency toward the modern <0o > in 1525, further decline in 1530 brings the margin of difference back down to just 20\%. However, as in 
Pynson, the <oo> spellings are dominated by $\operatorname{good}(e)$, accounting for almost all <oo $>$ variants in the 1530 Text $\mathrm{B}$, with a single instance of soone, and all but three examples occurring in Text A. The spelling of / $\mathrm{u}$ // was certainly far from complete or even established by 1530, and remained a variant localised to just a handful of lexical items, dominated by the repetitive occurrence of good. It is quite obvious that the spelling of / $\mathrm{o}$ / and /u:/, presented as a single, largely orthographic development in several books on fifteenth-century English, are most certainly two individual changes which have very little relationship with one another. The distinction between the close and open-mid vowels appears to have developed in two parts - the first a very rapid shift to complete <o> spellings in / $\mathrm{o}$ / items, essentially complete by 1525; the second a slower change towards <oo> spellings in /u:/ items, which by 1530, has hardly begun. Specifically differentiating between these two sounds seems to have been unimportant for early printers, and such developments occur later in the sixteenth century. 


\section{Orthography Conclusion}

The morphological forms studied largely followed a similar pattern, in that de Worde and Pynson were continuing well-established forms, as the innovative variants had, for the most part, overtaken the earlier remnants of the ME inflectional system. The story with phonology, and how this is represented on the page, however, is very different. Every form (except for <o> representing / $\mathrm{o} /$ ) were foundin 1490 to be aminor alternative to the established conservative ME variants, some of which showed no signs of decline in other fifteenth-century evidence. From these relatively traditional beginnings, the development of these variants throughout the next forty years differed significantly between the two printers, with definitive and interesting trends and styles that tended mostly towards the modern variant.

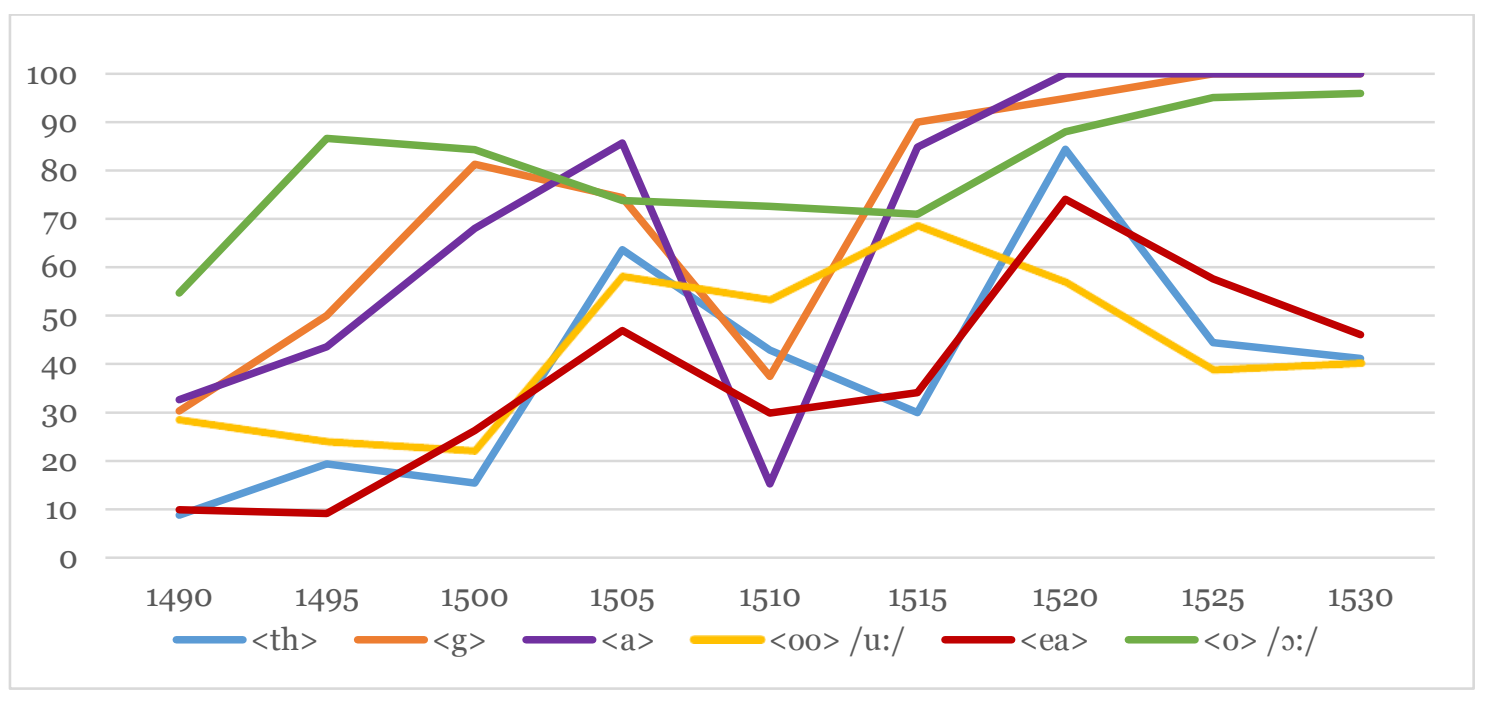

Fig. 2.12. Overall modernisation of orthographic forms in Richard Pynson.

Pynson's orthography, despite a number of irregularities, is still progressing towards modernity. What is interesting is the apparent 'split' between forms, which manifests in 1520. The division between $\langle\mathrm{g}\rangle,\langle\mathrm{a}\rangle$, and $\langle\mathrm{o}\rangle$, and $\langle\mathrm{th}\rangle,\langle 00\rangle$, and $<\mathrm{ea}\rangle$, progresses evenly in 1525 , and by 1530 is clearly marked. The $<$ ea $>$ and the $<$ th $>$ variants, which were relatively recent fifteenth-century introductions to the English language, follow an extremely similar pattern of development, rising and declining almost in unison, particularly from 1510 onwards. The <oo > rendering of /u:/, while less irregular and dramatic, seems to follow this same basic shape - flat, or little development before 1500, a rapid increase and subsequent decline between 1505 and 1515, and finally, more growth and weakening, ending rather flatly in 1530. These three ragged lines show a degree of instability and uncertainty which, in 1530, is not yet resolved. Because of this awkward flip-flopping and relatively low final percentage (the three modern variants still account for less than half of examples by 1530), it is easy at first glance to dismiss these results as a failure and claim this is evidence of widespread irregularity. To do so not only contradicts 
the nature of language change as it is understood in an academic context, but also ignores the basic statistic that, while it may not be a steady progression by any means, the use of $<$ th $>$, <ea $>$, and $<00>$ increased by $26 \%$ in just forty years, a rate which is still a significant achievement.

The other three innovative variants represented in this graph $-<\mathrm{g}>$, nasal $<\mathrm{a}>$, and $\langle 0\rangle$ representing / $/$ /, paint a starkly different picture which is more regular and conclusive. While $<\mathrm{o}>$ is already quite popular, $<\mathrm{a}>$ and $<\mathrm{g}>$, themselves not yet prevalent in the fifteenth century, were still minor variants of the distinctively medieval $<0>$ and $<y>$. Rather than a series of increasing peaks and declines as seen above, the development of $\langle$ g $\rangle,\langle\mathrm{a}\rangle$, and $\langle 0\rangle$ is steady, consistent, and with $90 \%$ representation by 1520 , proves conclusively that the modern spellings are entrenched in Pynson's texts at the end of his career. The only outlier to this trend occurs in 1510 , when both $\langle\mathrm{a}\rangle$ and $\langle$ g $>$ declined sharply in both the Text A and the Text B. As discussed above, the most reasonable explanation for this sudden resurgence of conservative spellings is either a brief employment of a new proofer or copyist attempting to enforce these older variants, or simply a case of traditional spellings being preserved from the two copy-texts of this sample year. 1510 is an obvious inconsistency, and the immediate return to the modern variants in 1515 suggests that this is not necessarily representative of the spellings of Pynson's printing house as a whole. It must be concluded then that the spelling of these three forms was a rapid, sweeping shift at a speed so dramatic and conclusive that it is simply indefensible to put down to chance or accident. The close-bound, highly patterned shift of these certain orthographic forms in Pynson's texts present a picture of a modern printing house which promoted (whether consciously or unconsciously) innovative spelling across a range of phonetic and lexical items.

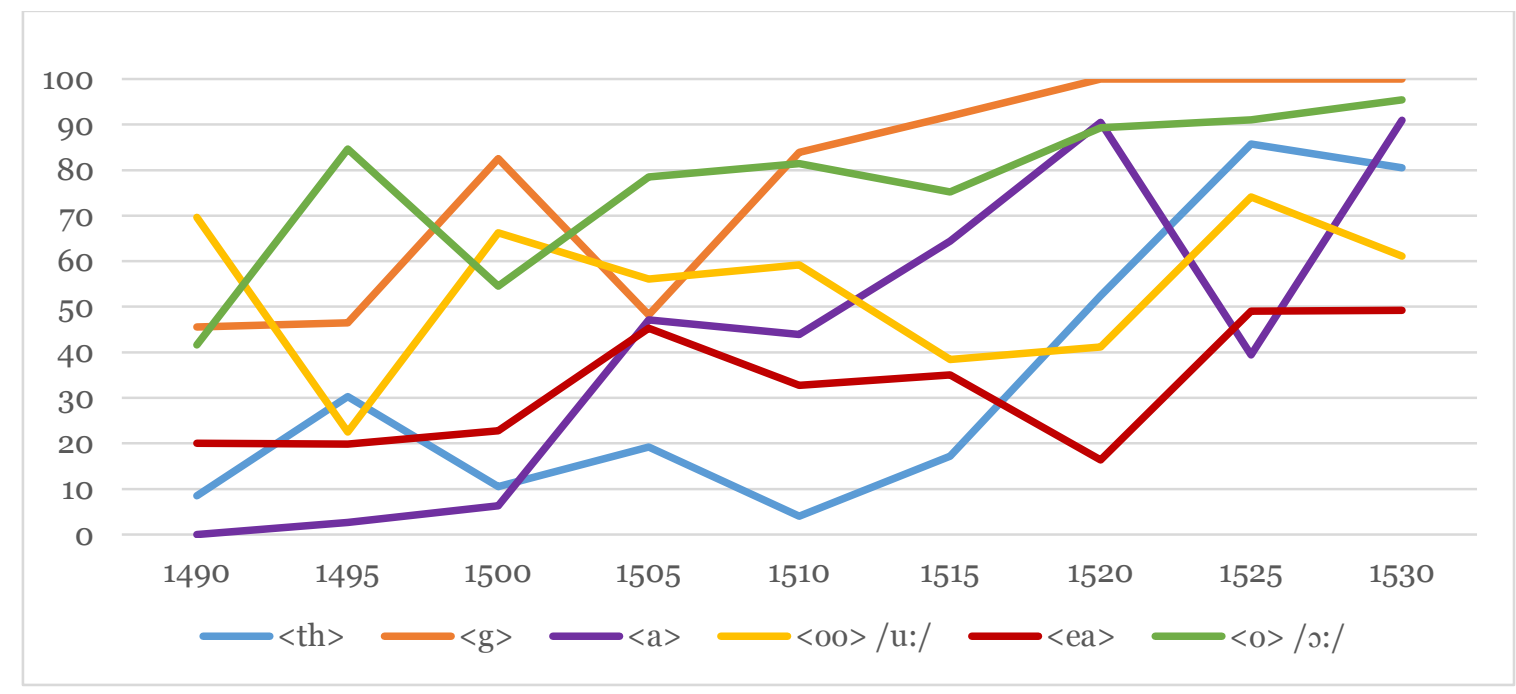

Fig. 2.13. Overall modernisation of orthographic forms in Wynkyn de Worde. 
The development of these same variants in the house of de Worde is significantly more varied than that of Pynson, although it still trends quite clearly towards a largely modern system by 1530 . Once again, the years 1490 and 1495 are relatively static, the only major shift occurring in the spelling of / $\mathrm{o}: /$ and / $\mathrm{u}$ /, which appear to be an experimental effort to spell all lexical items with both phonemes as $<0\rangle$. The changes in de Worde's text on the whole appear far more regular and even than in Pynson's, with fewer dramatic increases and decreases of variants. Rather than patterned rising and falling, de Worde's texts appear to advance more slowly, sometimes in a seemingly random and incoherent manner, and after 1500 there are very few jagged peaks indicating a very rapid increase and decline. Although de Worde's forms are less ordered than Pynson's and it is hard to discern any significant trends across two or more variants, it is undeniable that the data in 1530 is statistically more convincing, as every single modern variant, except <ea> (resting on $49.2 \%$ ), accounts for over $60 \%$ of recorded instances in the sample texts. Although there may be less obvious structure behind de Worde's spelling patterns over time the period studied, the evidence is sound; $\langle\mathrm{g}\rangle,\langle 0\rangle$, and $\langle\mathrm{a}\rangle$ (barring the inconsistency of $<\mathrm{a}>$ in 1525, as discussed above) are all well established in 1520, and the other three variants all increase dramatically between 1520 and 1525, which is maintained in 1530 . All six forms are nearly fully modern at this stage, with the conservative spellings mostly relegated to minor, relict variants.

It is difficult to define the relationship between the spoken and written shape of a certain phonological form during this time period, and any conclusions drawn will always be careful speculation. It is dangerous to assume that the printing house 'must' have indiscriminately used a particular variant in speech simply because it was the dominant form in print, and this is not what I am trying to argue; the preservation of conservative spellings in a number of contexts, the frequent inconsistencies from one year to the next, and the sometimes incoherent pattern of distribution over long periods of time are all evidence of a varied and dynamic system of spelling and speech. However, to label this environment disorderly and resistant to change as a number of scholars have done (Salmon 25; Upward and Davidson 84; Hellinga 113) disregards the visible patterns of variation between innovative and conservative spellings and the development towards modernisation and standardisation as witnessed in these phonological and orthographic forms. 


\section{Conclusion}

It is commonplace to categorise and divide the history of the English language into the three general periods of Old, Middle, and Early Modern English, a tradition which derives from the German philological studies of the nineteenth century. It is the boundary between ME and eModE which is most problematic to define with any certainty; such divisions tend to follow social, cultural, and political movements rather than any linguistic shifts. Dates from 1476 (The Cambridge History of the English Language; Upward and Davidson 85) to 1540 (Partridge 13) have been suggested, although 1500 seems the most popular approximation (Dobson; Görlach, Early Modern English 9; Baugh and Cable). Such a divisions are arbitrary and imperfect, done largely for the sake of convenience, and "divisions between linguistic periods are of course no sharper than those between regional dialects: on either side of a chosen divide we find clearly characterisable or 'core' varieties" (Lass, Cambridge Vol. 2 24). While the evidence collected, processed, and discussed in this thesis allows conclusions to be drawn with some confidence that there is a significant change in the language of both Richard Pynson and Wynkyn de Worde between the initial and final years of their long careers, it is impossible to affix a specific point at which the "middle" forms studied became "modern", often even within a single form. Nevertheless, there are still a number of qualified conclusions to be drawn about print, language and the works produced in the houses of Richard Pynson and Wynkyn de Worde.

The relationship between language and text in the early sixteenth century is strongly influenced by the printer, a new and radical addition to an established literary culture. Writers, translators, and readers traditionally looked back to and invoked the literature of the previous century, rather than to the future and the unknown, and printing was initially seen as a possible tool of preservation. The words in Robert Copland's epilogue of de Worde's 1530 Parliament of Fowls embody this sensibility:

And where thou become so ordre thy langage

That in excuse thy prynter loke thou haue

Whiche hathe the kepte frome ruynous domage

In snowe wyte paper / thy mater for to saue

With thylke same langage that Chaucer to the gaue

In termes olde / of sentence clered newe

Than methe moche sweter / who can his mynde auewe.

(STC 5092)

Copland's idea of "langage" is defined chiefly by style and vocabulary, and looks distinctly backwards. To him, the role of the printing press is to "facilitate the recovery of all that is good from the literary past" (Gillespie 123). This is essentially the common perception of 
the time; spelling and morphology are both tied to the perceived authority of the work, and are rarely considered by writers or printers with any sort of detail (Horobin, Chaucer Tradition 87; Blake Caxton 187, 193). There are numerous reference to "langage" and "Englyssh" throughout early printed texts: Caxton writes in his introduction to the Polychronicon that he "som what haue chaunged the rude and old Englyssh, that is wete certayn wordes which in these days be neither vsyd ne understanden" (STC 13438). In his 1506 Kalendar of Shepherds, Pynson decries the "corrupt englysshe" that "no man coude understonde" of the first translation (completed in Scots by a young Alexander Barclay), and the text was freshly translated from the French, the Scots unintelligible (STC 22408). The anonymous translator of Benedict's rule mentions the "playne, rounde englisshe" (STC 1859) compared to the original Latin, which is most likely to be a reference to vocabulary. Wyatt, struggling with his translation of Plutarch's De Tranquilitate Animi, apologises for the "shorte maner of speche", claiming that while Latin may have a "plentuouseness and faire diuersyte of langage" there is a "lacke of such diuersyte" in English (STC 20058.5). The writers and printers here are discussing vocabulary and style, rather than spelling. While there is more self-awareness of English in this period, the idea of 'correctness' in writing or spelling is still yet to develop (Gray 127, 129), and such factors are clearly not the concern of the writers and readers of this period. Despite being classified as "Early Modern" by most scholars, literature of the late fifteenth and early sixteenth centuries is still "medieval in form and spirit" (Lewis 1), and although the language and composition of the texts themselves are certainly more modern in the latter half of this period, the genre and style of the words published by Pynson and de Worde do not shift from the literary culture of the fifteenth century; in the early sixteenth century, "tradition and convention (whether conscious or not) continue to exercise a strong influence" (Gray 145). It is only after 1520 that this perception is first challenged, but such texts are still exceptions to a well-established norm. There is no conscious movement to modernise English either in form, style, or spelling. The disconnect between the rapid, widespread language change in the late fifteenth and the early sixteenth century, and the distinctly traditional literary culture and concept of "langage" in this period suggest the development of English phonology, orthography, and morphology were all occurring below the level of consciousness.

The great variety of material studied here illustrates how language can be shaped through form, genre, and style. The frequency of conservative spellings and morphological forms is usually strongest in older texts, first written in the latter half of the fifteenth century. Such texts were most common in the 1490's when printing was still in its infancy and neither de Worde nor Pynson were prepared or able to extend beyond this conventional market. The sample texts in this period are familiar prose works with numerous manuscript copies extant; Dives and Pauper, The Festial, The Chastising of 
God's Children, The Travels of Sir John Mandeville, and the Ars Moriendi. The turn of the sixteenth century saw the first steps away from this tradition, as Pynson and de Worde sought to fill their presses with material that was 'new' - works were composed by contemporary authors, or translated from French and Latin sources, both current and medieval. As mentioned above, new verses are largely imitative: "in the work of Hawes and Barclay, of the young Thomas More, and of Skelton, all the medieval characteristics survive" (Lewis 127). Although the structure, content, and character of the newly written texts reflected that of the previous generation, it is in this period that the first significant shifts in both morphology and orthography are visible, particularly in the works printed by Pynson, which had been reasonably conservative before this time. Between 1500 and 1530, the development of these forms, while at times irregular, nevertheless increased at a pace much more vigorous than before. Although conservative spellings were occasionally changed in copy-texts, as evidenced by the data gathered from de Worde's 1515 and 1530 reprints of the Myracles texts, such modernisation is considerably slower than the variants copied from contemporary copy-texts. Examples of the textual modification during the printing process is apparent, but perhaps not as prevalent as scholars tend to suggest. The printer, with an eye for style and vocabulary but not orthography, appears to be generally a transmitter of these innovative spellings rather than a pioneer (Fisher, “Caxton” 166).

Although it may not be possible to determine exactly who is responsible for linguistic change within these printed texts, the direction and scope of these changes can still be established. Traditionally accepted theories on the development of English, particularly in the fifteenth and sixteenth centuries, tend to trace a line from the Chancery scribes, to the early printers, to the Early Modern orthoepists. The influence the orthoepists really had on the English language has recently been challenged. John Hart's mid-sixteenth century publications aimed to create an entirely new spelling system, rather than regularising current orthography, and should not necessarily be regarded as the inspiration for sixteenth-century printers (Rutkowska 10). Richard Mulcaster's 1582 Elementarie, intended as a contribution towards standardisation, demonstrates "many instances of unreformed spellings frowned on", and 36 of the first 136 spellings in Coote's 1596 English School-maister "do not achieve modernity" (Howard-Hill 16). Scholars who argue that the early printers are disruptive of this progression focus chiefly on the divergence between them and Chancery as evidence (Scragg 67; Görlach, Early Modern English 46; Upward and Davidson 84), and the validity of Chancery as a precursor of 'Standard English' is widely stated (Samuels, "Middle English Dialectology" 44; Hernandez-Campoy and CondeSilvestre, Chancery Practices 45; Fisher, Chancery English 5). The data collected here (and several observations noted by other scholars), however, suggested something quite different. Within the Chancery documents, conservative morphological and orthographic 
variants tho, fro, intervocalic $<\mathrm{d}>,<\mathrm{y}>$ spelling of $/ \mathrm{g} /$, and $<\mathrm{e}>$ spelling of $/ \varepsilon$ :/ were all dominant, hem, ne, and /o:/ spelling <0o> were preferred, /u:/ spelling < <o > is only a slim majority, and more is the only innovative form which is regular in Chancery. Some innovative variants, such as intervocalic $<$ th $>$ and nasal $<a>$, first found popularity in private correspondence, such as the Paston letters, and pronunciations such [g] / in give/again and long [i:] (the phonological changes which lie behind two of the orthographic shifts studied) are identified by scholars as first appearing in 'non-standard' or 'vulgar' speech (Dobson 548; Samuels, "Spelling and Dialect" 51). Geographical mobility is also apparent; two variants, the <g> / in give/again and them, were initially northern, spreading southwards in the late fourteenth and fifteenth centuries with the rise of urban migration. Of the ten forms studied, all (except perhaps more) were on some level influenced by geographical or social variation, particularly in the fifteenth century. The traditional notion that language change is introduced or diffused only by those with a high social standing has been thoroughly disproven, and it is now an accepted fact that linguistic innovation can take place in any social group and disperse until it is accepted as standard (Labov 286).

Most occurrences of language change are thought to progress below the conscious awareness of the speakers (Nevalainen, Raumolin-Brunberg, and Mannila 26), whereas an attempt to enforce standardisation of English through Chancery Standard would have been more visible than extant evidence indicates. There is no doubt that Chancery was hugely influential in the development of 'Standard English' as an early standardised variety, but it was not a case of the system's prestige leading to widespread, autonomous replication (Evans 188). It is evident from this study (and a number of others) that a number of developments, both orthographic and morphological, were initially found not in the papers and petitions of the Chancery scribes, but in the informal writings of the middle classes, in itself a relatively new phenomenon. There is a proven link between the rise of reading and writing within these social groups, and of innovative variants perceived as non-standard and initially localised to the middle classes and socially mobile groups (Nevalainen and Raumolin-Brunberg, Historical Linguistics; Sociolionguistics and Language History; Conde-Silvestre and Hernandez-Campoy, "Chancery Practices"; "Linguistic Innovation"; Evans, Queen Elizabeth). Norman Blake admits that while "certain forms show a movement towards the standard associated with Chancery English... this is not true for all forms" and "if the pull of this new standard was as strong as suggested by Fisher, one might perhaps have expected rather more standardisation than one actually finds." ("Wife of Bath's Prologue" 22). This is clearly the change in process here; the young, educated, socially mobile professionals working in the houses of Pynson and de Worde reflect these innovative spellings, some of which were still considered "vulgar", more strongly than the prestige Chancery Standard of the previous generation. This tendency is visible in the development 
of both morphology and orthography. The spelling in the 1490 texts demonstrates a closeness with the conservative Chancery variants, but by 1530 a number of language changes (including the beginnings of the GVS, language contact, analogical levelling) are moving throughout the London speech community.

Is standardisation then an appropriate expression to use in this situation? It is clear that aspects of the text such as morphological and phonological spellings were beyond the concerns of the printing-house, as the concept of language focused on style and lexis. This distinction is critical when assessing the 'standardisation' of orthography in Pynson and de Worde's texts. It seems unfair to assign a modern perception of regularity to a non-modern text. The closest signs of orthographic regularity are the initial movements of lexical diffusion and analogical levelling; the spelling of good when all other lexical items containing /u:/ are still spelled toke or boke, the tendency to spell moost after the development of / :/ was otherwise almost complete, the spreading of the <ea $>$ grapheme from ME origin to OE origin lexical items, the analogical dispersion of intervocalic $<\mathrm{th}>$, and the variation between nasal $<0>$ and $<$ a $>$ in de Worde's texts, all show how modern variants tended very often to begin with one lexical item or group of items, and spread to the rest of the phoneme. The only exception to this trend appears to be the variants $\langle\mathrm{y}\rangle$ and $\langle\mathrm{g}\rangle$, which interchanged quite freely in the 1490s. This pattern of development - the borrowing of individual words or word-spellings - noted quite strongly within these texts is arguably the most common consequence of language contact, and can be found within dialects and varieties as well as languages (Labov 308). In this regard, there are certainly elements of orthographic regularity, some expressed as early as 1490, which by 1530 are diffusing throughout a phoneme, with the innovative variant clearly dominant.

Assessing the language of the highly transitional period of the late fifteenth and early sixteenth centuries is a problematic task, as the language is fraught with abnormalities and inconsistencies, and to evaluate the product of the large printing houses run by Richard Pynson and Wynkyn de Worde, even more so. After intensive analysis, however, several trends can be identified. The morphological forms at the beginning of the period are inherently less conservative, and shift conclusively towards innovative variants which by 1530 are largely assumed as standard. The orthography of the texts, in particular the phonological spellings, is far more complex. This development is influenced by the copy-text, and the failed attempts at systematic and regular orthography as projected by a number of scholars contradicts the notion of language as perceived by writers and printers of the period. The pattern of variation appears to be centred on linguistic and analogical diffusion, which by 1530 is apparent, if not complete across all forms. Finally, the assumption that the language of the early printers stems directly from Chancery appears to be incorrect. Many forms are socially directed towards variants appropriated by the writers of the texts and members of the 
printing house. There is a substantial level of linguistic development in the years 1490-1530, as the houses of Pynson and de Worde merge these innovative, "middle-class" orthographic and morphological variants with the established Chancery forms, and the final texts reflect genuine progress towards standardisation and modernity. 


\section{List of Texts}

In the catalogue that follows, editorial titles have largely been adapted from the STC, and appropriately noted when taken from the incipit, explicit or title-page proper. Editorial titles (such as The Festial) are given when the given title is unclear. Texts belonging to Duff's catalogue of fifteenth-century texts are also identified. Dates given are sourced either from the texts themselves, or from the estimated date given by the STC. The 'source' here is used as an umbrella term which means either the copy-text (if identified), or the non-English text from which it was translated. When a text is identified as a 'first publication', this means that the particular edition is (on the basis of extant evidence) the first time the text has been circulated, either in manuscript or print. Where applicable, the modern edition has been noted. In some cases, a modern edition of the copy-text, a previous imprint, or a text belonging to the same manuscript tradition exists, and when this has occurred, they have also been included for reference. Information about the text, such as the date of original composition, genre, identity of the translator and/or author, and other such information is included where relevant.

\section{Pynson 1490 Text A}

A compendiouse treetise dyalogue. of Diues \& paup[er]. that is to say. the riche \& the pore [explicit]

Printed: 1493 [dated in text]

$464 \mathrm{p}$.

STC: 19212

Duff: 339

Source: Bodl. MS Eng.th.d.36.

Modern edition: Barnum, Priscilla, ed. Dives and Pauper. EETS OS 323.

Anonymous devotional text, initially attributed in error to Henry Parker, and first written in English sometime between 1405 and 1410. It is an unusually long prose treatise, which debates the practical meaning of the Ten Commandments in the fifteenth century. Pynson's source text has been dated to around 1500 (Barnum $l x x v$ ). Printing costs (for 600 copies) were halved between Pynson and the London merchant John Russhe, a matter which was eventually settled in the courts (Plomer, Wynkyn de Worde 115-7). The text was reprinted twice; once by de Worde (the 1495 Text A) and once by Thomas Berthelet in 1532.

\section{Pynson 1490 Text B}

The helpe and grace of almighty god [incipit] [The Festial]

Printed: 1493 [STC dating]

$216 \mathrm{p}$.

STC: 17960

Duff: 303

Source text: STC 17959 (Westminster: Caxton, 1491)

Modern edition: Powell, Susan, ed. John Mirk’s Festial. EETS OS 335

A collection of medieval sermons written by John Mirk in the late 1380's, and one of the most popular works of religious prose in fifteenth-century England, with 21 manuscript copies extant (Powell xliii). The Festial was printed at least 22 times in both English and Latin by a number of foreign printers as well as Caxton, Pynson, and de Worde. However, it fell very quickly out of fashion about the time of the Reformation, and after 1532 was never reprinted. 


\section{De Worde 1490 Text A}

This tretyse is of loue and spekyth of iiij of the most specyall louys that ben in the worlde [incipit]

Printed: 1493 [dated in text]

$96 \mathrm{p}$.

STC: 24234

Duff: 399

Source text: unknown [new translation]

Modern edition: Fisher, John H., ed. The Tretyse of Loue. EETS OS 223

An anonymous devotional treatise, adapted from the Ancrene Riwle (Fisher, Tretyse xiii). The text was translated from a French source in 1493, by a "Right well disposed persone", who "also caused the sayd boke to be enprynted", as stated in the explicit. Although the exact source has not been identified, an MS from the same tradition (MS Français 2292) suggests it came from the Burgundian court in the 1470s (Fisher, Tretyse xv). Caxton's device still features on the last page. No other surviving editions of this text remain.

\section{De Worde 1490 Text B}

The prouffytable boke for ma[n]nes soule, and right comfortable to the body, and specyally in aduersitee [and] trybulacyon, whiche boke is called The chastysing of goddes chyldern [title]

Printed: 1493 [STC dating]

$96 \mathrm{p}$.

STC: 5065

Duff: 85

Source text: unknown

Modern edition: Bazire and Colledge, ed. The Chastising of God's Children and the Treatise of the Perfection of the Sons of God. Oxford: Blackwell, 1957.

Anonymous devotional text. Written in the south of England between 1382-1400 (Bazire and Colledge 37), the text is a guide against temptation and suffering, aimed particularly at women (Windeatt 259). Fourteen manuscript copies survive (Bazire and Colledge 1), and the textual relationship between these copies indicates very many more manuscript copies must have been lost. It is not certain which manuscript served as de Worde's copytext (Bazire and Colledge 37). The text was apparently reprinted several times, although these do not appear to be noted in the STC (37).

\section{Pynson 1495 Text A}

the boke of Iohn Maunduyle knyght of wayes to Ierusalem [explicit]

Printed: 1496 [STC dating]

$144 \mathrm{p}$.

STC: 17246

Duff: 285

Source text: unknown

Modern edition: none

A travel narrative, written originally in French c. 1360 by a supposed "John Mandeville" who is now considered fictitious (Tzanaki 3). The text was extremely popular in the fourteenth and fifteenth centuries, with over three hundred manuscripts extant across Europe (1). The popular English version is a c. 1400 translation of the Anglo-Norman, 
with 38 surviving manuscript copies (16). Pynson's text stems from this version, although the exact copy-text is unclear. The text was reprinted four times before 1510 by Wynkyn de Worde, and much later, by Thomas East in 1568, which sparked a revival of interest.

\section{Pynson 1495 Text B}

Here begynneth a lityll treatyse short and abrydgyd spekynge of the art and crafte to knowe well to dye [incipit] [Ars Moriendi]

Printed: 1495 [STC dating]

$32 \mathrm{p}$.

STC: 790

Duff: 36

Source text: STC 789 (Westminster: Caxton, 1490)

Modern edition: Atkinson, David, ed. The English Ars Moriendi. New York: Peter Lang, 1992.

Anonymous devotional text, instructing the reader on the art of dying through deathbed prayer. Originally written in Latin in 1415, the Ars Moriendi is one of the most prominent religious texts of the fifteenth century, with hundreds of manuscript copies extant in almost every major European language ( $N C E$ "Ars Moriendi”). Pynson's copy is a reprint of Caxton's 1490 translation, from an unknown contemporary French source. The Ars Moriendi was popular, published six times by Caxton, Pynson, de Worde, and Robert Wyer before 1532, after which it disappeared.

\section{De Worde 1495 Text A}

Diues [et] Pauper [title]

Printed: 1496 [dated in text]

$392 \mathrm{p}$.

STC: 19213

Duff: 340

Source text: STC 19212 (London: Pynson, 1493)

Modern edition: Barnum, Priscilla. Ed. Dives and Pauper. EETS OS 323.

A reprint of Richard Pynson's 1493 edition. See Pynson 1490 Text A.

\section{De Worde 1495 Text B}

The myracles of oure blessyd lady [title]

Printed: 1496 [STC dating]

$56 \mathrm{p}$.

STC: 17539

Duff: 297

Source text: unknown

Modern edition: Whiteford, Peter, ed. The Myracles of Oure Lady: Ed. from Wynkyn de Worde's Edition. Heidelberg: C. Winter, 1990.

Anonymous collection of miracles featuring the Virgin Mary. Similar texts began appearing in Latin during the twelfth century, and enjoyed considerable popularity. The Myracles is very likely to have been translated from a Latin collection, but no source has been identified. However, it has certain similarities with a fifteenth-century manuscript at Sidney Sussex College, Cambridge 95 (Whiteford 28). The text was reprinted by de Worde in 1515 with slight revisions, and then again in 1530. 


\section{Pynson 1500 Text A}

The traduction \& mariage of the princesse [title]

Printed: 1500 [STC dating]

$16 \mathrm{p}$.

STC: 4814

Duff: suppl. 6

Source text: first publication

Modern edition: none

Anonymous pamphlet detailing an early draft of public plans of the marriage between Arthur, Prince of Wales, and Catherine of Aragon. Many details of the pamphlet were changed before the wedding itself. The text mentions the "monethe of August or of Septembre next coming", suggesting the date of composition is either 1500 or early 1501. As the information inside the text was only correct for a short time, the text was not reprinted.

\section{Pynson 1500 Text B}

The book of good manners [STC title]

Printed: 1500 [STC dating]

$196 \mathrm{p}$.

STC: 15396

Duff: 250

Source text: STC 15394 (Westminster: Caxton, 1487)

Modern edition: none.

Conduct text, covering a range of topics on good behaviour, such as the church, death, virtue, and vice. The book was first written by Jacques Legrand ca. 1410, (titled Livre do Bormor Mam) and then translated and printed by Caxton in 1487, a task commissioned by William Pratt. Six editions were published before 1526; two by Pynson, one by Caxton, and three by de Worde.

\section{De Worde 1500 Text A}

Here begynneth a ryght profytable treatyse compendiously drawen out of many dyuers wrytynges [incipit]

Printed: 1500 [STC dating]

$36 \mathrm{p}$.

STC: 1978

Duff: 43

Source text: first publication

Modern edition: none

A collection of devotional miscellanea compiled, written, and translated by Thomas Betson (d. 1516), a librarian and deacon of the Bridgettine abbey of Syon, Middlesex (DNB "Betson, Thomas"). The work includes fundamental religious texts, such as the Pater Noster, Ave Maria, Seven Sacraments, and Ten Commandments, as well as translated excerpts from Gerson, St. Bernard, St. Jerome, and St. Bridget. No other editions have survived.

\section{De Worde 1500 Text B}

Here begynneth the lyf of saint katherin of senis the blessid virgin [incipit]

Printed: 1500 [STC dating]

$192 \mathrm{p}$. 
STC: 24766.3

Duff: 403a

Source text: STC 24766 (Westminster: De Worde, 1492)

Modern Edition: none

An anonymous translation of Raymond of Capua's late fourteenth-century Legenda maior of St. Catherine of Siena. The translation was presumably produced after her canonisation in 1461 (Arnold and Lewis 105). De Worde's original source text is lost, but a MS from the same tradition (British Library, Royal 17.D.v [fols $59^{\mathrm{r}}-62^{\mathrm{r}}$ ]) indicates it was in English (Schultze 190). De Worde printed the text three times before 1520, after which it disappeared. Boscard's 1609 edition is an Italian translation of Raymond of Capua's work and unrelated to de Worde's text.

\section{Pynson 1505 Text A}

The mirroure of golde for the synfull soule [title] [Speculum aureum animae peccatricis] Printed: 1506 [STC dating]

$108 \mathrm{p}$.

STC 6894.5

Source text: USTC 70685 (Bréhan-Loudéac: Robin Fouquet, 1484) [new translation] Modern edition: Lady Margaret Beaufort, trans. The Imitation of Christ and The Mirror of Gold to the Sinful Soul TEAMS: Middle English Texts series. Forthcoming. [editor unknown]

A translation, by Lady Margaret Beaufort, of book IV from Jacobus de Gruytrode's (ca. 1400-1475) Specula, addressed specifically to those of the "secular world". The source has been as identified a printi from Paris in 1484 (Nugent 385). It was reprinted four times before 1526; three times by de Worde, and once by John Skot.

\section{Pynson 1505 Text B}

[h]e[re b]egyn[n]eth the Kalender of Shepherdes [title]

Printed: 1506 [date in text]

$168 \mathrm{p}$.

STC: 22408

Source text: $G W 05908$ (Paris: Guy Marchant, 1493) [new translation]

Modern edition: none

A collection of miscellaneous matter, including science, poetry, and religion. Frequently published in French, the first English translation was undertaken by a young Alexander Barclay in 1503, at the behest of Parisian printer Antoine Vérard (Duff, "Work of the Press" §17). Pynson, rejecting Barclay's Scots translation as "corrupt englysshe", had the book translated from French at his own cost. The text was translated once more by Robert Copland in 1518 for publication in de Worde's house (STC 22409). This third translation was popular and reprinted seventeen times, as late as 1656 .

\section{De Worde 1505 Text A}

Here begynneth the boke called the example of vertu [title]

Printed: 1504 [STC dating]

$92 \mathrm{p}$.

STC: 12945

Source text: first publication

Modern edition: Gluck, Florence and Alice Morgan, eds. Minor Poems of Stephen Hawes; Advice, Coronation of Henry VIII. EETS OS 271 
A verse text in praise of clean virtues, written by Stephen Hawes, groom of Henry VII, in 1504 and "presented to our sayd souerayne lorde". The text was reprinted once by de Worde 1530.

\section{De Worde 1505 Text B}

thystorye of ye vii. wyse maysters of Rome conteynynge ryghte fayre right ioyous

narracons to ye reder right delectable [incipit]

Printed: 1506 [STC dating]

$172 \mathrm{p}$.

STC: 21298

Source text: STC 21297 (London: Pynson, 1493 [fragment])

Modern edition: none

A collection of didactic stories with a narrative structure dating back to Late Antiquity, and translated anonymously from a Latin source dated to 1475 (Campbell xxiv). The source is identified as Pynson's 1493 fragment by the STC. The text was printed twenty times (but only three before 1560), with varying degrees of accuracy, until the late eighteenth century (Campbell $l x v$ ).

\section{Pynson 1510 Text A}

the pylgrymage of Sir Richarde Guylforde Knyght controuler vnto our late soueraygne lorde kynge Henry the. vij. And howe he went with his seruauntz and company towardes Iherusalem [title]

Printed: 1511 [dated in text]

$120 \mathrm{p}$.

STC: 12549

Source text: first publication

Modern edition: Ellis, Henry, ed. The Pylgrymage of Sir Richard Guylforde to the Holy Land, A.D. 1506. London: Camden Society, 1851.

A travel narrative, written partially by Sir Richard Guildford (c.1450-1506) and prepared by his chaplain. Guildford, an administrator and councillor for Henry VII, made the pilgrimage to the Holy Land after his removal from royal office. He died in Jerusalem in September 1506 (DNB "Guildford, Sir Richard") and the text was returned along with his will to England. Pynson published the account shortly after, and text was not reprinted.

\section{Pynson 1510 Text B}

This treatyse concernynge the fruytfull saynges of Dauyd the kynge [title]

Printed: 1510 [dated in text]

$276 \mathrm{p}$.

STC: 10905

Source text: first publication

Modern edition: none

A collection of sermons based on the biblical seven penitential psalms written and delivered by John Fisher. According to the prologue, the sermons were printed at the request of Lady Margaret Beaufort. The text was printed five times between 1508 and 1510 by de Worde and Pynson. After some time, three more editions were printed, the last in 1555 . 


\section{De Worde 1510 Text A}

This sermon folowynge was compyled [and] sayd in the cathedrall chyrche of saynt Poule within ye cyte of London by the ryght reuerende fader in god Iohn bysshop of Rochester, the body beyinge present of the moost famouse prynce kynge Henry the. $v i j$. [title]

Printed: 1509 [dated in text]

$24 \mathrm{p}$.

STC: 10900

Source text: first publication

Modern Edition: Hymers, J., ed. The Funeral Sermon of Margaret, Countess of Richmond and Derby. Cambridge: Cambridge University Press, 1901.

A publication of the sermon delivered by John Fisher at the funeral of Henry VII, centred theologically on the first psalm of David. Although it is similar to Fisher's previously published collection of sermons on the seven psalms (the first printing of which is the Pynson 1510 Text B), it appears to be shortened for the purpose of the funeral. The prologue claims Lady Margaret Beaufort requested the sermon to be printed. The sermon was published twice in 1509 but afterwards vanished.

\section{De Worde 1510 Text $B$}

The gospelles of dystaues [title]

Printed: 1510 [STC dating]

$60 \mathrm{p}$.

STC: 12091

Source text: unknown [new translation]

Modern edition: Jeay, Madeleine, and Kathleen Garay, eds and trans. The Distaff Gospels. Peterborough: Broadview Press, 2006.

A contemporary translation of the Distaff Gospels, a rustic fifteenth-century French collection of popular domestic beliefs held by women. The translator names himself as $\mathrm{H}$. W. in the text, identified as Henry Watson by the STC. Eleven early printed texts in French survive, indicating strong popularity in France, but it unknown which of these texts were de Worde's source (Jeay and Garay, 27). No other English editions of the text have survived.

\section{Pynson 1515 Text A}

Anno septimo. henrici. viii. Statuta [title]

Printed: 1516 [STC dating]

$32 \mathrm{p}$.

STC: 9362.6

Source text: first publication

Modern edition: none

A publication of the statutes of Parliament, held on November 2, 1516. As the King's Printer, Pynson published an edition of newly-passed laws and statutes almost every year from 1508 , until his retirement in 1528 . The 1516 statues were reprinted five times in large compendiums containing the laws of Parliament throughout Henry VIII's reign.

\section{Pynson 1515 Text B}

Here begynneth the Rule of seynt Benet [title]

Printed: 1516 [dated in text]

88 p. 
STC: 1859

Source text: unknown [new translation]

Modern edition: none

A translation of St. Benedict's book of precepts written at some point early in the sixth century, recognised as the most important factor in the spread of monasticism in the west. The text was widely copied and translated, with over 130 commentaries extant (NCE "Rule of St. Benedict"). The introduction states that the book is printed at the commandment of Richard Foxe, Bishop of Winchester (1448-1528), and translated into "commune, playne, rounde englisshe" to be distributed among "certayne deuoute and religiouse women" who "haue no knowlege nor vnderstondinge" of Latin. No other editions of the text in this form appear to exist.

\section{De Worde 1515 Text A}

The fruyte of redemcyon [title]

Printed: 1514 [dated in text]

$48 \mathrm{p}$.

STC: 22557

Source text: first publication

Modern edition: none

A devotional text written by Simon the Anchorite (fl. 1512-1529), describing the life and passion of Christ. The text was printed five times before 1533 , four by Wynkyn de Worde, and once by Robert Redman.

\section{De Worde 1515 Text B}

The myracles of our lady [title]

Printed: 1514 [dated in text]

$48 \mathrm{p}$.

STC: 17540

Source text: STC 17539 (Westminster: De Worde, 1496)

Modern edition: Whiteford, Peter, ed. The Myracles of Oure Lady: Ed. from Wynkyn de Worde's Edition. Heidelberg: C. Winter, 1990.

A reprint of the 1496 edition. See de Worde 1495 Text B.

\section{Pynson 1520 Text A}

Here begynneth the lyfe of the blessed martyr Saynte Thomas [incipit]

Printed: 1520 [STC dating]

$16 \mathrm{p}$.

STC: 23954

Source text: unknown

Modern edition: none

An anonymous biography of St. Thomas Becket. As an immensely popular figure throughout the Middle Ages, works on the life of St. Thomas are numerous. The STC claims the text is borrowed from Caxton's 1483 Golden Legend, but the hagiography of St. Thomas is just five pages long and is quite different in style (STC 24873). There are no references to a possible author or translator and no modern edition of the text has been published. John Rastell published a verse text on the life of St. Thomas (existing in a single fragment) in 1520 (STC 2394.3), although this dating is uncertain (Devereux 133). The two texts appear unrelated. It is fairly likely that more contemporary texts on the life of St. 
Thomas were produced (which could have shed light on the textual history of this work), but were lost after Henry VIII's 1538 proclamation discrediting his martyrdom and ordering his erasure from written works (Biggs, Erasing Becket).

\section{Pynson 1520 Text B}

Here begynneth a lytell Cronycle / translated \& imprinted at the cost \& charge of Rycharde Pynson. by the commaundement of the ryght high and mighty prince / Edwarde duke of Buckingham / yerle of Gloucestre / Staffarde / and of Northamton. [title] [La fleur des histoires de la terre d'Orient.]

Printed: 1520 [STC dating]

$96 \mathrm{p}$.

STC: 13256

Source text: unknown [new translation]

Modern edition: Burger, Glenn, ed. A Lytell Cronycle: Richard Pynson's Translation (c 1520) of La Fleur Des Histoires de la Terre D'Orient (c 1307). Toronto: University of Toronto Press, 1988. Toronto Medieval Texts and Translations 6.

An account of major historical and contemporary events in the Near East, particularly the Armenian Kingdom and the Mongol Empire, originally written by Hayton of Corycus and dictated to his scribe in 1307 (Burger $\mathrm{x}$ ). The text was printed at "cost and charge" of Pynson, but at the commandment of Lord Edward Stafford, an educated patron of the arts (Burger xxxv).

\section{De Worde 1520 Text A}

Here begynneth a lytell treatyse of the turkes lawe called Alcaron. And also it speketh of Machamet the nygromancer [title]

Printed: 1519 [STC dating]

$12 \mathrm{p}$.

STC: 15084

Source text: first publication [new translation]

Modern edition: none

Although there is no authorship attributed within the text, it has been taken from Sir John Mandeville's Travels and altered (Gray 15), with "Machamete the Prophet" rewritten as "Machemete the Nygromancer" (Ledyard 249) and Saracens recast as Turks (Gray 15). The text as it stands in this edition has not been reprinted.

\section{De Worde 1520 text $B$}

The sermon of Iohn the bysshop of Rochester made agayn the pernicious doctryn of Martin luther [title]

Printed: 1521 [STC dating]

$44 \mathrm{p}$.

STC: 10894

Source text: first publication

Modern edition: Hatt, Cecilia, ed. English Works of John Fisher, Bishop of Rochester: Sermons and Other Writings 1520 to 1535. Oxford: Oxford University Press, 2002.

A publication of the sermon delivered by St. John Fisher on May 12, 1521, denouncing the doctrine of Martin Luther, and England's "first public assertion of orthodoxy" (Hatt 49). The text was reprinted once by de Worde in 1522. 


\section{Pynson 1525 Text A}

Here begynneth the famous cronycle of the warre, which the romayns had agaynst

Iugurth vsurper of the kyngdome of Numidy [title] [Bellum Juguthinum]

Printed: 1525 [STC dating]

$182 \mathrm{p}$.

STC: 21627

Source text: STC 21626 (London: Pynson, 1522)

Modern Edition: Waite, Greg, ed. Sallusts Jugurthine Wars. EETS OS 344. (Forthcoming)

An English translation of Sallust's Jugurthine War, written in 41-40BC. Alexander Barclay translated the text at the commandment of Thomas Howard, 3rd Duke of Norfolk, and Barclay's English is printed in parallel with the Latin. Three editions survive; a 1521 edition, the 1525 reprint (this text), and an edition by John Waley in 1557.

\section{Pynson 1525 Text B}

Here begynneth a lytell treatyse in Englysshe, called the extripacion of ignorancy and it treateth and speketh of the ignorance of people [title]

Printed: 1526 (STC dating)

$36 \mathrm{p}$.

STC: 4186

Source text: first publication

Modern edition: none

A moral treatise in verse, written by Paul Bush (1490-1558), bishop of Bristol and a poet of moderate renown (DNB "Bush, Paul”). The poem is dedicated to Henry VII's daughter, Princess Mary, and is thoroughly medieval in its orthodox spirituality. The text was not reprinted.

\section{De Worde 1525 Text A}

Here is co[n]teyned the lyfe of Iohan Picus erle of Myrandula a grete lorde of Italy an excellent connynge man in all sciences [title]

Printed: 1526 [STC dating]

$80 \mathrm{p}$.

STC: 19898

Source text: STC 19897.7 (London: Rastell, 1510)

Modern edition: Edwards, Anthony, et. al., eds. The Complete Works of St. Thomas More. Vol. 1. New Haven: Yale University Press, 1963.

A translation, by Thomas More, of Giovanni Francesco's (1470-1533) 1496 Vita of his uncle, the humanist Italian philosopher Pico della Mirandola (1463-1494) takes up approximately a third of the volume, the rest of which are More's translations of a selection of Pico's own commentaries, letters, and prose works. More's source has been identified as a 1504 edition of the Opera Omnia (USTC 679674) (xxxviii). There is some dispute about the date of composition - some scholars agree that it was probably composed in 1504-5, when More decided to marry rather than be a priest (Lehmberg 70), but William Rastell claims in 1557 that the text was translated from the Latin in 1510, and there is no solid reason to disagree with this claim (Edwards et. al. xxxvii). The text is dedicated to Joyce Leigh, a nun and childhood friend of More's (Edwards et. al. xl), and intended initially as a private devotional work (Lehmberg 70). The text was first printed in 1510 by John Rastell, reprinted by de Worde in 1525 (this text), and printed once more by William Rastell in 1557. 


\section{De Worde 1525 Text B}

The ymage of loue Here foloweth a goostly pamphlete or mater copendyously extract of holy scrypture, and doctours of ye chyrche, called ye ymage of loue, very necessary for all vertuous persones to loke vpon. [title]

Printed: 1525 [dated in text]

$52 \mathrm{p}$.

STC: 21471.5

Source text: first publication

Modern edition: none [discussed in detail within Lawler et. al., eds. The Complete Works of St. Thomas More. Vol. 6 Part II. New Haven: Yale University Press, 1981, 729-755]

A religious treatise, initially anonymous, translated by John Gough. The Ymage of Love was controversial for its eschewing of the devotional apparatus of the church in favour of a spiritual turning to God directly (Lawler et. al. 741). Both Gough and de Worde were taken to court for breaking new ecclesiastical regulations on censoring heretical texts, and de Worde was instructed to recall the 120 copies already distributed and cease all remaining sales (734). Four copies of the 1525 edition are extant (731), and the text was heavily attacked in More's Dialogue Concerning Heresies in 1528, suggesting the Ymage was still being circulated despite the court order. The 1532 reprint censors the controversial passages, and cites John Ryckes as the compiler. The third edition, printed by John Charlewood in 1587 near the height of anti-Catholic feeling in England, is greatly altered and anti-papist in tone. The text cites a second author, a Dominican friar named Adrian Savorine who is probably fictitious (733).

\section{Pynson 1530 Text A}

Tho. wyatis translatyon of Plutarckes boke, of the quyete of mynde [De tranquilitate animi] [title]

Printed: 1528 [STC dating]

$56 \mathrm{p}$.

STC: 20058.5

Source text: unknown [new translation]

Modern edition: Baskerville, ed. Plutarch's Quyete of Mynde: Translated by Thomas Wyat. Cambridge, Mass.: Harvard University Press, 1931. [Facsimile, with introduction and notes]

Thomas Wyatt's version of Guillaume Budé's (1467-1540) Latin translation of Plutarch. The work was finished on "the last day of Decembre. M.D.xxvij" at the commandment of Princess Catherine of Aragon. No other editions of the text survive - a 1589 print by Robert Robinson is an entirely different translation.

\section{Pynson 1530 Text B}

A copy of the letters, wherin the most redouted mighty pri[n]ce, our souerayne lorde kyng Henry the eight, kyng of Englande [and] of Frau[n]ce, defe[n] sor of the faith, and lorde of Irla[n]de: made answere vnto a certayne letter of Martyn Luther [title]

Printed: 1527 [STC dating]

$100 \mathrm{p}$.

STC: 13086

Source text: first publication

Modern edition: none [detailed summaries of all three letters are in Brewer, J., ed. Letters 
and Papers, Foreign and Domestic, Henry VIII. Vol. 4 - 1524-1530. London: Longman \& Co, 1870. ]

A translation from Latin of three letters; one from Henry VIII to the public, one from Martin Luther to Henry VIII, written in 1524, and the final by Henry VIII in response. The identity of the translator is not known, nor is it mentioned anywhere in the text that the letters are translations. The text was reprinted by Pynson twice in 1528 .

\section{De Worde 1530 Text A}

A werke for housholders or for them $y^{t}$ haue the gydynge or gouernaunce of any company [title]

Printed: 1530 [dated in text]

$64 \mathrm{p}$.

STC: 25422

Source text: STC 25421.8 (London: Redman, 1530)

Modern edition: none

The text is composed of two parts. The first fifty-six pages is a guide to householders written by Richard Whitford. The last eight, probably included to bring the page count up the typical 32 quarto leaves, are from Bernard Silvester's (fl. 1136) Care or Governance of Household, translated by Whitford. The exact date of composition of the core text, and translation of the supplementary text is unknown (Lawrence 155). Seven editions of the werke for householders were published between 1530 and 1533 by Redman, Treveris, and de Worde.

\section{De Worde 1530 Text $B$}

The myracles of our lady [title]

Printed: 1530 [dated in text]

STC: 17541

Source text: 17540 (London: De Worde, 1515)

Modern edition: Whiteford, Peter, ed. The Myracles of Oure Lady: Ed. from Wynkyn de Worde's Edition. Heidelberg: C. Winter, 1990.

A reprint of the 1496 edition. See de Worde 1495 Text B. 


\section{Works Cited}

Anderson, John and Charles Jones. Phonological Structure and the History of English. Amsterdam: North-Holland Publishing Company, 1977. Print.

Armstrong, A. M., et. al. The Place-Names of Cumberland: Eskdale, Cumberland and Leath Wards. Cambridge: Cambridge University Press, 1950. Print. The English Place-Name Society, 20.

Arnold, John, and Katherine J. Lewis. A Companion to the Book of Margery Kempe. Cambridge: DS Brewer, 2004. Print.

Aronoff, Mark. “The Orthographic System of an Early English Printer: Wynkyn de Worde.” Folia Linguistica Historica. 8.1-2. (1989): 65-97. Print.

Atkinson, David, ed. The English Ars Moriendi. New York: Peter Lang, 1992. Print.

Barber, Charles. Early Modern English. 2nd ed. Edinburgh: Edinburgh University Press, 1997. Print.

Barnum, Priscilla. Dives and Pauper. Oxford: Oxford University Press, 1976. Print. Early English Text Society Original Series 323.

Baskerville, ed. Plutarch's Quyete of Mynde: Translated by Thomas Wyat. Cambridge, Mass.: Harvard University Press, 1931. Print.

Baugh, Albert Croll, and Thomas Cable. A History of the English Language. 5th ed. London: Routledge, 2006. Print.

Bazire, Joyce, and Eric Colledge, eds. The Chastising of God's Children and the Treatise of the Perfection of the Sons of God. Oxford: Blackwell, 1957. Print.

Bennett, H S. English Books \& Readers, 1475 to 1557: Being a Study in the History of the Book Trade from Caxton to the Incorporation of the Stationers' Company. Cambridge: Cambridge University Press, 1952. Print.

Benskin, Michael. "Some New Perspectives on the Origins of Standard Written English.” Dialect and Standard language in the English, Dutch, German and Norwegian Language areas. Proceedings of the Colloquium 'Dialect and Standard Language', Amsterdam, 18-18 October, 1990. Ed. J. A. Leuvensteijn and J. B. Berns. Amsterdam: Leuvensteijn Koninklijke Nederlandse Akademie van Wetenschappen, 1992. Print. 
---. “Chancery Standard.” New Perspectives on English Historical Linguistics. Selected Papers from 12 ICEHL, Glasgow, 21-26 August 2002, Volume II: Lexis and Transmission (2002): 1-40. Print.

Biggs, Sarah. "Erasing Becket”. Medieval Manuscripts Blog. British Library, September 2011. Web. 19 May 2014.

Björkman, Erik. Scandinavian Loan-Words in Middle English. Part I. Tübingen: Max Niemeyer, 1900. Print.

Blades, William. The Life and Typography of William Caxton, England's First Printer. Vol. 1. London: Trübner \& Co., 1877. Print.

Blake, Norman. "English Versions of Reynard the Fox in the Fifteenth and Sixteenth Centuries." Studies in Philology 62.1 (1965): 63-77. Print.

---. Caxton and His World. London: Andre Deutsch, 1969. Print. The Language Library.

---. "Chancery English and the Wife of Bath's Prologue". To Explain the Present: Studies in the Changing English Language in Honour of Matti Rissanen. Ed Terru Nevalainen and Leena Kahhlas-Tarkka. Helsinki: Societé Neophilologique, 1997. 3-24. Print.

Brewer, J., ed. Letters and Papers, Foreign and Domestic, Henry VIII. Vol. 4 - 1524-1530. London: Longman \& Co., 1870. Print.

Briggs, Charles. "Literacy, Reading, and Writing in the Medieval West." Journal of Medieval History. 26.4 (2000): 397-420. Print.

Brown, William. Yorkshire Deeds. Cambridge: Cambridge University Press, 1922. Print.

Bühler, Curt. The Fifteenth Century Book: The Scribes, the Printers, the Decorators. Philadelphia: University of Pennsylvania Press, 1960. Print.

Burger, Glenn, ed. A Lytell Cronycle: Richard Pynson's Translation (c 1520) of La Fleur Des Histoires de la Terre D’Orient (c 1307). Toronto: University of Toronto Press, 1988. Print. Toronto Medieval Texts and Translations 6.

Burrow, J. A., Thorlac Turville-Petre. A Book of Middle English. 2nd ed. Oxford: Blackwell, 1992. Print.

Campbell, Killis. The Seven Sages of Rome. Boston: Ginn \& Company, 1907. Print. 
Conde-Silvestre, Juan Camilo, and Juan Manuel Hernandéz-Campoy. "A Sociolinguistic Approach to the Diffusion of Chancery Written Practices in Late Fifteenth Century Private Correspondence.” Neuphilologische Mitteilungen 105.2 (2004): 133-152. Print.

---. "Sociolinguistic and Geolinguistic Approaches to the Historical Diffusion of Linguistic Innovation: Incipient Standardisation in Late Middle English.” International Journal of English Studies 5.1 (2005): 101-134. Print.

Conner, Jack E. “The History of Double Vowels in English Spelling.” Diss. Stanford University, 1953. Print.

Cressy, David. Literacy and Social Order: Reading and Writing in Tudor and Stuart England. Cambridge: Cambridge University Press, 1980. Print.

Cusack, Bridget. “Not Wreton With Penne and Ynke': Problems of Selection Facing the First English Printer.” Edinburgh Studies in English and Scots. Eds. A. J. Autken et al. London: Longman 1971. 29-54. Print.

Davis, Norman. "The Language of the Pastons." Proceedings of the British Academy 40. (1955): 119-140. Print.

---. Paston Letters: Selected and Edited with an Introduction. Oxford: Clarendon Press, 1958. Print. Clarendon Medieval and Tudor Series.

---. "The Language of Two Brothers in the Fifteenth Century." Five Hundred Years of Words and Sounds: A Festschrift for Eric Dobson. Eds. E.G. Stanley and Douglas Gray. Cambridge: D. S. Brewer, 1983. Print.

---. "Notes on Grammar and Spelling in the Fifteenth Century." The Oxford Book of Late Medieval Verse and Prose. Ed. Douglas Gray. Oxford: Clarendon, 1985. 493-508. Print.

Devereux, E. J. Bibliography of John Rastell. Kingston: McGill-Queen’s University Press, 1999. Print.

Dictionary of Old English Corpus. Eds. Antoinette DePaolo Healy et. al. University of Toronto, 2009. Web. 24 Apr. 2014.

Dobson, E. J. English Pronunciation 150o-1700. 2nd ed. Oxford: Clarendon Press, 1968. Print. 
Duff, Gordon. "The Introduction of Printing into England and the Early Work of the Press." The Cambridge History of English and American Literature: An Encyclopedia in Eighteen Volumes. 1908: vol. 2. Print.

---. A Century of the English Book Trade; Short Notices of All Printers, Stationers, BookBinders, and Others Connected with It from the Issue of the First Dated Book in 1457 to the Incorporation of the Company of Stationers in 1557. Folcroft: Folcroft Library Editions, 1972. Print.

Duff, Gordon and Lotte Hellinga. Printing in England in the Fifteenth Century: E. Gordon Duff's Bibliography, with Supplementary Descriptions, Chronologies and a Census of Copies London: Bibliographical Society, 2009. Print.

Early English Books Online. ProQuest LLC, 2003. Web.

Edwards, Anthony, et. al., eds. The Complete Works of St. Thomas More. Vol. 1. New Haven: Yale University Press, 1963. Print.

Ekwall, Eilert. A History of Modern English Sounds and Morphology. Oxford: Blackwell, 1975. Print.

Ellis, Henry, ed. The Pylgrymage of Sir Richard Guylforde to the Holy Land, A.D. 1506. London: Camden Society, 1851. Print.

Erler, Mary C. “Wynkyn de Worde’s Will: Legatees and Bequests.” The Library 6.10 (1988): 107-121. Print.

Evans, Mel. The Language of Queen Elizabeth I: A Sociolinguistic Perspective on Royal Style and Identity. Malden: Wiley-Blackwell, 2013. Print.

Fischer, Olga. "On Negative Raising in the History of English." Negation in the History of English. Ed. Ingrid Tieken-Boon van Ostade, et. al. Berlin: Mouton de Gruyter, 1998. 55100. Print.

Fischer, Olga and Wim van der Wuff. "Syntax.” A History of the English Language. Ed. Denison and Hogg. Cambridge: Cambridge University Press, 2006. 109-199. Print.

Fisher, John H. "Caxton and Chancery English.” Fifteenth-Century Studies: Recent Essays. Hamden: Archon Books, 1984. Print.

---. An Anthology of Chancery English. Knoxville: University of Tennessee Press, 1984. Print. 
---. The Tretyse of Loue. Oxford: Oxford University Press, 1951. Print. Early English Text Society Original Series 223.

Fisher, John and Diane Bornstein. In Forme of Speche Is Chaunge; Readings in the History of the English Language. Englewood Cliffs: Prentice-Hall, 1974. Print.

Freeborn, Dennis. From Old English to Standard English. 2nd ed. Ottawa: University of Ottawa Press, 1998.

Furnivall, Frederick, and Paul Hamelius. The Digby Plays: With an Incomplete "Morality" of Wisdom, Who is Christ (Part of One of the Macro Moralities). Oxford: Oxford University Press, 1896. Print. Early English Text Society Extra Series 70.

Geipel, John. The Viking Legacy: The Scandinavian influence on the English and Gaelic Languages. Newton Abbot: David \& Charles, 1971. Print.

Gillespie, Alexandra. Print Culture and the Medieval Author: Chaucer, Lydgate, and Their Books, 1473-1557. Oxford: Oxford University Press, 2006. Print. Oxford English Monographs.

Gluck, Florence and Alice Morgan, eds. Minor Poems of Stephen Hawes; Advice, Coronation of Henry VIII. Oxford: Oxford University Press, 1974. Print. Early English Text Society Original Series 271.

Gómez-Soliño, José. "William Caxton y la Estandardizacion de la Lengua Inglesa en el Siglo XV”. Revista Canaria de Estudios Ingleses. 10 (1985): 95-118. Print.

Görlach, Manfred. Studies in the History of the English Language. Heidelberg: C. Winter, 1990. Print. Anglistische Forschungen, 210.

---. Introduction to Early Modern English. Cambridge: Cambridge University Press, 1991. Print. Gray, Douglas. Later Medieval Literature. Oxford: Oxford University Press, 2008. Print.

Hanna, Ralph. The English Manuscripts of Richard Rolle. Liverpool: Liverpool University Press, 2010. Print. Exeter Medieval Texts and Studies.

Hatt, Cecilia, ed. English Works of John Fisher, Bishop of Rochester: Sermons and Other Writings 1520 to 1535. Oxford: Oxford University Press, 2002. Print.

Hellinga, Lotte. William Caxton and Early Printing in England. London: British Library, 2010. Print. 
Herren, Michael. "Latin and the Vernacular Languages" Medieval Latin: An Introduction and Bibliographical Guide. Eds. F. A. C. Mantello and A. G. Rigg. Washington D.C.: Catholic University of America Press, 1996. 122-130. Print

Hirsh, Rudolph. The Printed Word: Its Impact and Diffusion. (Primarily in the 15th-16th Centuries). London: Variorum Reprints. 1978. Print.

Hodgson, Phyllis. The Cloud of Unknowing and the Book of Privy Counsel. Oxford: Oxford University Press, 1944. Print. Early English Text Society Original Series 218.

Hogg \& Denison. A History of the English Language. Cambridge: Cambridge University Press, 2006. Print.

Hooper, Joan B. An Introduction to Natural Generative Phonology. New York: Academic Press, 1976. Print.

Horobin, Simon C. P. “The Language of Fifteenth-Century Printed Editions of The Canterbury Tales.” Anglia. 119.2 (2001): 249-258. Print.

---. The Language of the Chaucer Tradition. Cambridge: D. S. Brewer, 2003. Print.

Howard-Hill, T. H. "Early Modern Printers and the Standardization of English Spelling." The Modern Language Review 101.1 (2006): 16-29. Print.

Howe, Stephen. The Personal Pronouns in the Germanic Languages: A Study of Personal Pronoun Morphology and Change in the Germanic Languages from the First Records to the Present Day. New York: Walter de Gruyter, 1996. Print. Studia Linguistica Germanica 43.

Hymers, J., ed. The Funeral Sermon of Margaret, Countess of Richmond and Derby. Cambridge: Cambridge University Press, 1901. Print

Iyeri, Yoko. “Unsupported Negative Ne in Later Middle English.” The Oxford Journals: Notes and Queries. 55.1 (2008): 21-23. Print.

Jeay, Madeleine, and Kathleen Garay, eds and trans. The Distaff Gospels. Peterborough: Broadview Press, 2006. Print.

Jones, Charles. A History of English Phonology. London; New York: Longman, 1989. Print. Longman Linguistics Library. 
Kristensson, Gillis. A Survey of Middle English Dialects, 1290-1350: The Six Northern Counties and Lincolnshire. Lund: Gleerup, 1967. Print.

Kökeritz, Helge. Shakespeare’s Pronunciation. New Haven: Yale University Press, 1953. Print.

Labov, William. Sociolinguistic Patterns. Philadelphia: University of Pennsylvania Press, 1972. Print.

Lass, Roger. "Phonology and Morphology." A History of English. Eds. David Denison and Richard Hogg. Cambridge: Cambridge University Press, 2006. 43-108. Print.

---. "Phonology and Morphology." The Cambridge History of the English Language. $1^{\text {st }}$ ed. Eds. Norman Blake. Vol. 2. Cambridge: Cambridge University Press, 1992. 23-155. Print.

---. "Phonology and Morphology." The Cambridge History of the English Language. $1^{\text {st }}$ ed. Eds.

Roger Lass. Vol. 3. Cambridge: Cambridge University Press, 2000. 56-186. Print.

---. Historical Linguistics and Language Change. Cambridge: Cambridge University Press, 1997. Print. Cambridge studies in Linguistics 81.

---. The Shape of English: Structure and History. London: Dent, 1987. Print.

Lathrop, Henry Burrowes. Translations from the Classics into English from Caxton to Chapman, 1477-1620. University of Wisconsin, 1933. Print.

Lawler et. al., eds. The Complete Works of St. Thomas More. Vol. 6 Part II. New Haven: Yale University Press, 1981. Print.

Lawrence, Veronica. "The Life and Writings of Richard Whitford”. Diss. University of St Andrews, 1988. Print.

Ledyard, Gleason. And to the Eskimos. Chicago: Moody Press, 1958 Print.

Lehmberg, Stanford E. "Sir Thomas More's Life of Pico Della Mirandola." Studies in the Renaissance 3 (1956): 61-74. Print.

Lewis, C. S. English Literature in the Sixteenth Century: Excluding Drama. Oxford: Oxford University Press, 1973. Print. Oxford History of English Literature Series.

Lodge, K. R. "Dependency Phonology and English Consonants.” Lingua 54.1 (1981): 19-39. Print.

Liuzza, Roy. "Orthography and Historical Linguistics.” Journal of English Linguistics 24 (1996): 25-44. Print. 
Mare, Albinia de la. Vespasiano Da Bisticci, Historian and Bookseller. London: London University, 1965. Print.

Marthaler, Berard, exec. ed. New Catholic Encyclopedia. 2nd ed. Detroit: Thompson-Gale, 2003. Print.

Matheson, Lister. Rev. of An Anthology of Chancery English by John H. Fisher. Speculum 61.3 (1986): 646-650. Print.

Mazzon, Gabriella. A History of English Negation. London: Pearson-Longman, 2004. Print.

McIntosh, Angus, et al., eds. A Linguistic Atlas of Late Mediaeval English. 4 vols. Aberdeen: Aberdeen University Press, 1986. Print, web. Accessed May 2014.

McKenzie, Donald Francis. “Apprenticeship in the Stationers' Company, 1555-1640.” Library 5.13 (1959): 292-99. Print.

---. "Printers of the Mind: Some Notes on Bibliographical Theories and Printing-House Practices" Making Meaning: "Printers of the Mind" and Other Essays. Amherst: University of Massachusetts Press, 2002. 13-85. Print.

Millar, Robert. English Historical Sociolinguistics. Edinburgh: Edinburgh University Press, 2012. Print. Edinburgh Textbooks on the English Language - Advanced.

Milroy, James. Linguistic Variation and Change: On the Historical Sociolinguistics of English. Oxford: Blackwell, 1992. Print. Language in Society 17.

Milroy, James, and Lesley Milroy. "Linguistic Change, Social Network and Speaker Innovation.” Journal of Linguistics 21 (1985): 339-384. Print.

Moxon, Joseph. Mechanick Exercises. London, 1683. Print.

Neuman, W. Lawrence. Social Research Methods: Qualitative and Quantitative Approaches. 7th Edition. London: Pearson, 2009.

Nevalainen, Terttu, and Helena Raumolin-Brunberg. Historical Sociolinguistics: Language Change in Tudor and Stuart England. London: Longman, 2003. Print.

---. Sociolinguistics and Language History: Studies Based on the Corpus of Early English Correspondence. Amsterdam: Rodopi, 1996. Print. 
Nevalainen, Terttu, Helena Raumolin-Brunberg, and Heikki Mannila. "The Diffusion of Language Change in Real Time: Progressive and Conservative Individuals and the TimeDepth of Change." Language Variation and Change 23.1 (2011): 1-43. Print.

Nevalainen, Terttu, and Ingrid Tieken-Book van Ostade. "Standardisation." A History of the English Language. Ed. Denison and Hogg. Cambridge: Cambridge University Press, 2006. 271-311. Print.

Nishimura, Hideo. "Decline of Multiple Negation Revisited.” Aspects of English Negation. Ed. Yoko Iyeri. Amsterdam: John Benjamins Publishing Company, 2005. Print.

Nugent, Elizabeth. The Thought and Culture of the English Renaissance. Cambridge: Cambridge University Press, 1956. Print.

Oxford Dictionary of National Biography. Oxford University Press, 2004. Web. May 2014.

Oxford English Dictionary Online. Oxford University Press, 200o. Web. April-June 2014.

Overty, Joanne Filippone. “The Cost of Doing Scribal Business: Prices of Manuscript Books in England, 1300-1483." Book History 11.1 (2008): 1-32. Print.

Page, William. "Parishes - Hemington." A History of the County of Northampton: Volume 3. British History Online, 2013. Web. 21 Apr. 2014.

Partridge, A.C. Tudor to Augustan English. London: André Deutsch Ltd., 1969. Print.

Patterson, Frank. "Hymnal of MS. Additional 34193: British Museum." Medieval Studies in Memory of Gertrude Schoepperle Loomis. New York: Columbia University Press, 1927: 443-488. Print.

Plomer, Henry Robert. William Caxton. (1424-1491). London: Parson, 1925. Print.

---. Wynkyn de Worde \& His Contemporaries from the Death of Caxton to 1535: A Chapter in English Printing. London: Grafton, 1925. Print.

Powell, Susan. John Mirk's Festial: Edited from British Library MS Cotton Claudius A.II. Oxford: Oxford University Press, 2010. Print. Early English Text Society Original Series 335 .

Pyles, Thomas. The Origins and Development of the English Language. 3rd ed. New York; London: Harcourt Brace Jovanovich, 1982. Print. 
Quinn, Heidi. The Distribution of Pronoun Case Forms in English. Amsterdam: John Benjamins, 2005. Print.

Quirk, Randolph and C. Wrenn. An Old English Grammar. 2nd ed. London: Methuen, 2002. Print.

Reames, Sherry. Middle English Legends of Women Saints. Kalamazoo: Medieval Institute Publications, 2003. Print.

Romaine, Suzanne. Socio-Historical Linguistics. Its Status and Methodology. Cambridge: Cambridge University Press, 1982. Print.

Rosenthal, Joel. "The Paston Letters". The Oxford Encyclopaedia of British Literature. Ed. David Scott Kastan. Oxford: Oxford University Press, 2006. Print.

Russ, Charles V. J. Historical German Phonology and Morphology. Oxford: Clarendon Press, 1978. Print. Oxford History of the German Language.

Rutkowska, Hanna. "Towards Regularisation: Morphological Spelling in Several Editions of the Kalendar of Shepherdes.” Studia Anglica Posnaniensia. 48.1 (2013): 8-28. Print.

Salmon, Vivian. "Orthography and Punctuation." The Cambridge History of the English Language. Ed. Roger Lass. Vol. 3. Cambridge: Cambridge University Press, 2000. 13-55. Print.

Samuels, M. L. "Some Applications of Middle English Dialectology.” English Studies 44.1. (1963): 81-94. Print.

---. “Spelling and Dialect in Late and Post-Middle English Periods.” So Meny People Longages and Tonges: Philological Essays in Scots and Mediaeval English Presented to Angus McIntosh. Eds. Benskin and Samuels. Edinburgh: M. Benskin \& M. L. Samuels, 1981. 4354. Print.

Schultz, Dirk. "Translating St Catherine of Siena in Fifteenth-Century England." Catherine of Siena: The Creation of a Cult. Ed. Jeffrey Hamburger and Gabriela Signori. Belgium: Brepols Publishers, 2013. 185-214. Print. Medieval Women: Texts and Contexts 13

Scragg, D. G. A History of English Spelling. Manchester, New York: Manchester University Press, 1974. Print. Mont Follick Series vol. 3. 
Sedgefield, Walter John. The Place-Names of Cumberland and Westmorland. Manchester: Manchester University Press 1915. Print.

Shaklee, Margaret. "The Rise of Standard English." Standards and Dialects in English. Ed. Shopin and Williams. Cambridge: Winthrop Publishing Company, 1980. 33-62. Print.

Smith, Bridget. "Dental Fricatives and Stops in Germanic: Deriving Diachronic Processes from Synchronic Variation.” Historical Linguistics 2007. Vol. 308. Philadelphia: John Benjamins, 2009. 19-36. Print.

Steinberg, S.H. Five Hundred Years of Printing. 3rd ed. Harmondsworth: Penguin Books, 1974. Print.

Tieken-Boon van Ostade, Ingrid. "The Origin and Development of the "Neg... Neither" Construction: A Case of Grammaticalisation.” Negation in the History of English. Ed. Ingrid Tieken-Boon van Ostade, et. al. Berlin: Mouton de Gruyter, 1998. 207-232. Print.

Twyman, Michael. The British Library Guide to Printing: History and Techniques. Toronto: University of Toronto Press, 1998. Print. The British Library Guides.

Tzanaki, Rosemary. Mandeville's Medieval Audiences: A Study on the Reception of the Book of Sir John Mandeville (1371-1550). Burlington: Ashgate, 2003. Print.

Ukaji, Masatomo. "On the Scope of Negative Concord”. Negation in the History of English. Ed. Ingrid Tieken-Boon van Ostade, et. al. Berlin: Mouton de Gruyter, 1998. 269-294. Print.

Upward, Christopher and Davidson, George. The History of English Spelling. Malden: WileyBlackwell, 2011. Print.

Waite, Greg, ed. Sallusts Jugurthine Wars. Oxford: Oxford University Press, forthcoming. Early English Text Society Original Series 344 .

Werner, Otmar. "The Incorporation of Old Norse Pronouns into Middle English. Suppletion by Loan.” Language Contact in the British Isles. Tübingen: Niemeyer, 1991. 369-41. Print.

Whiteford, Peter, ed. The Myracles of Oure Lady: Ed. from Wynkyn de Worde's Edition. Heidelberg: C. Winter, 1990. Print. Middle English Texts 23.

Windeatt, Barry, ed. "The Chastising of God's Children.” English Mystics of the Middle Ages. Cambridge: Cambridge University Press, 1994. Cambridge English Prose Texts. 
Wright, Laura. "Introduction." The Development of Standard English 1300-180o. Theories, Descriptions, Conflicts. Cambridge: Cambridge University Press, 2000. 1-8. Print.

Zachrisson, R. E. Pronunciation of English Vowels, 1400-1700. New York: AMS Press, 1971. Print. 